University of Rhode Island

DigitalCommons@URI

Open Access Dissertations

1961

\title{
The Relationship of Dopamine to Blood Pressure and Monoamine Oxidase Activity in Hypertensive Rats
}

David Rockwell De Fanti

University of Rhode Island

Follow this and additional works at: https://digitalcommons.uri.edu/oa_diss

\section{Recommended Citation}

De Fanti, David Rockwell, "The Relationship of Dopamine to Blood Pressure and Monoamine Oxidase Activity in Hypertensive Rats" (1961). Open Access Dissertations. Paper 495.

https://digitalcommons.uri.edu/oa_diss/495

This Dissertation is brought to you for free and open access by DigitalCommons@URI. It has been accepted for inclusion in Open Access Dissertations by an authorized administrator of DigitalCommons@URI. For more information, please contact digitalcommons-group@uri.edu. 
Tai RHATIOMBRP OF DOPNMTE TO BLOOD PRESSURE ATD MONONIRE OxIMSB MCIVITY IH

HXPERTMATVE BATS

BI

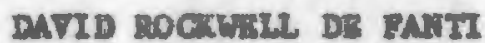

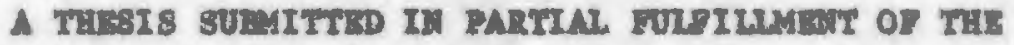
REOTREATHE FOR THE DBGRE OF DOCTOR OF PULLOSOPHY

(Finesedect)

UIVESITY OF RHOD ISLAMD

1961 
Docron of purlosopd thss

08

DAVID ROCKush De Fum

Apreved:

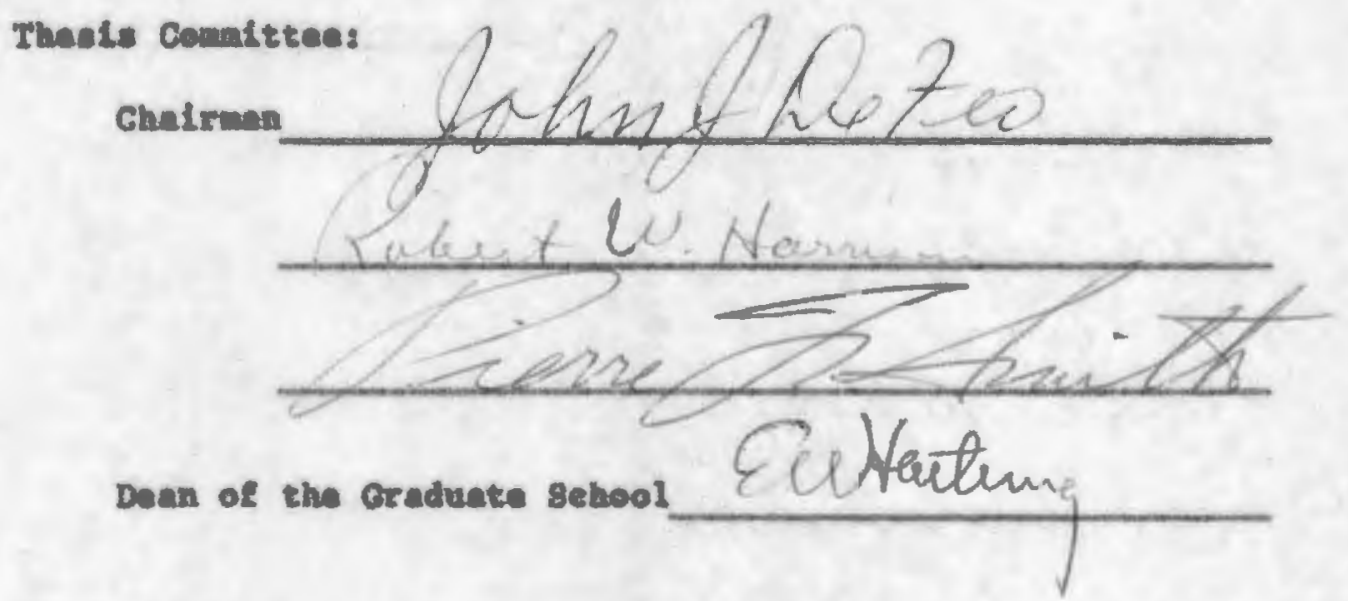

UHTVRSIT OF RHODS ISLND

1961 


\section{Acavosuspgmetrs}

The author vishes to exprea his sincere gratieude to Dr. John J. Deffeo, not only Eor his guidance and soelotance during the Investigation and preparation 02 this manuseript, but also for $\mathrm{Ml}$ guidance and inapira. tion throughout the entire period of foetoral study.

The author wiohes to axpres his olneare appreciation to Joel S. o Conner for his assiatanee and Ahleo eoncerning the otctictical analysis contsined harota.

The author wlahes to exprese his gratitude te the onlted states Public Health Service for Ite apport of this investigation through Restarch Fellowships wF-10,527 and me-20,527-ch. 


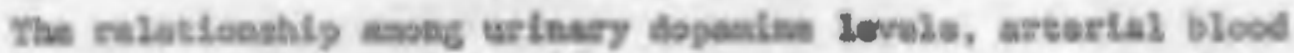

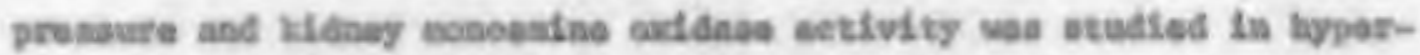
tenelve ele rate.

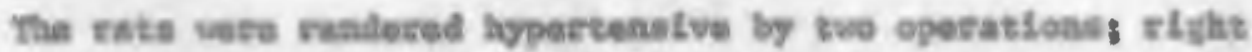
neplarcetong tollows is two weela by ecetralateral weal arterlal congresatoe.

The blood prasanres rose otcadily throuphout the flrat il weeka Dollowing the second oporatien asd at the ond of this perlod levelod ote at appousteately $100-135 \mathrm{men}$ N5.

Dopenine vas extraeted fron pooled urine samples by les exohange

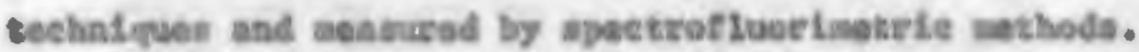

Dopanina lewila (wase troa pooled group tata) rose througbous the experlesntal perlod troa a eontrol vatus of 673 \& $166 \mu / \mathrm{h}$ to $1022 \$ 449 \mu / 2$. Tha rlales pastara of dopasine vas intarrupted by aharp decrenme burlag the sleventh and shirteesth veeks.

A Ifasar eorrelation, excluding somtrol velues asd values troa tha lant wak of the Lavestigation, wes eobitweted by regreastas blood presoure on logarithe dopentes eonematratioe. The analyals whlob wat

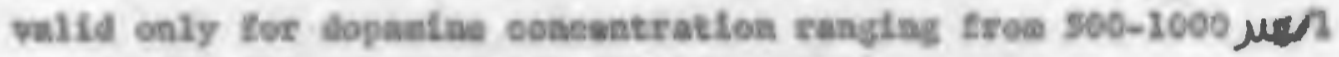
resulted in a tegrasioa coatristent of 0.05 and a coettielent of daternination of 5.72 , Indieating a talr degret of 1Lmen abboolation between the two pariabies.

Monoendse oxtdese sobivity dropped off starply Rolloulas the sebond operation, vent throegh wat appearod to so a eeapensatory riso, and thas dacressed to 40 pareent of fto original ectivity at the ond of the Invartigatloesl period. 
In considering the interrelationship anong the three variables, a definite eorrelation between Gopanine and the blood preasure was abown to exdat; hovever, a elear relationohip between dopasine and aonoasine oxidase Inhlbition vas not established. 


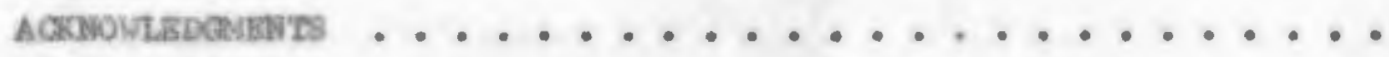

ABSTRATT ...........................

taBLR of CONTENTS .....................

LIST dE TABLSS .....................

LIST OR fIGURE ......................

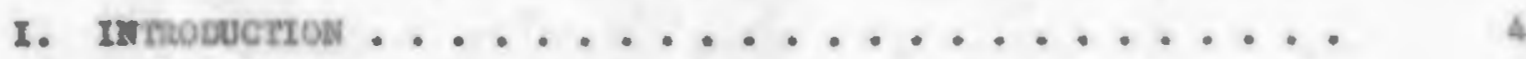

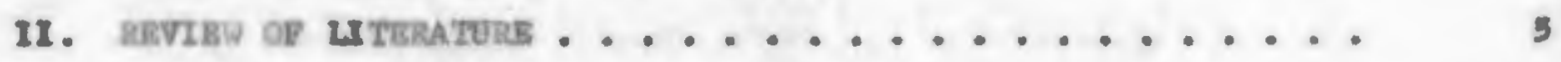

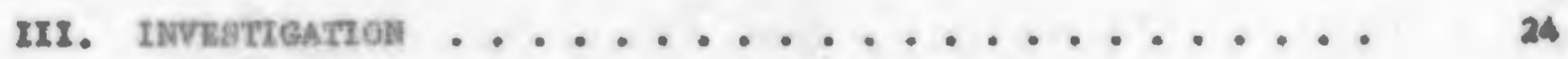

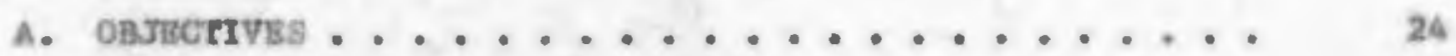

B. MaTRILLL AND MGTHODs ............... 24

1. Production of Bxporinatel Rypertension ...... 24

2. Collection of Vrine ............. 26

3. Bxtrection of Catecholandaes fron vria ...... 26

4. Deteralnatiog of Doparim ........... 27

5. Paper Chrometograjt. ............ 35

6. Blologícal Aacay ............. 34

7. Monoamine ordeaes Daternination ........ 35

c. meguts ............................... 37

1. Gontrol Group .................. 38

2. Indididual Test Grougs ............ 39

3. Pooled Data erom Individual Teet Groups...... 46

4. Stutlotlenl Analyols on Pooled Data ........ 50

IV. Drscussion ................................ 54

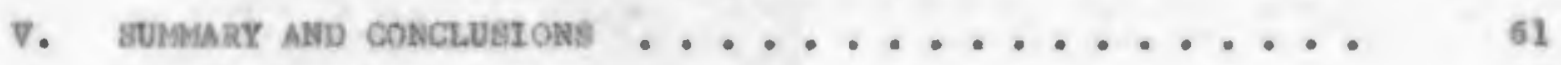

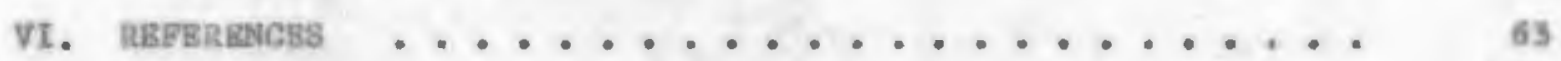




\section{List of raviss}

rable

1 Percent recovery of doposine added to urine ahing les.... 51

2 Percent dopsalna eluted vith 2.0 Ir hydroehloric ecid . . 32

5 Control group. Relationchip of arinary bopandine lowelo (pooled asaplee) to artorial blood pressure (group mean) and hidesy eonomalne oxilase aetivity in mele rat. ... 30

$4 \quad$ Group 1. Relationohip of urinary dopsaine levelo (pooled mamplea) to artertal blood pressure (srous neen) and kidney monoanine oxidase activity in mpertensive

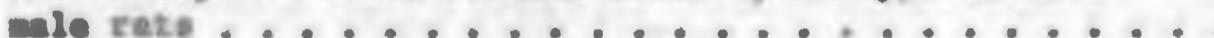

5 Group 2. Reletianship of urinery dopende Iovelo (pooled sanples) to arterlal blood prenoure (group non) and kidney monosiafne coldace setivity in byectenoive ale rate ........................

6 Group 3. Relationahip of uriacry dopasine lovelo (pooled saveleo) to arterlal blood preboure (exoup mean) and kidtuey nosoanin orden actiolty in hypertensive nale ratil ......................

7 Group A. Inletlonahip of urinury dopand ne levele (pooled sampled) to arterlal blood presoure (group mean) and kidney monoantine oxidaee activity In hypertenol w

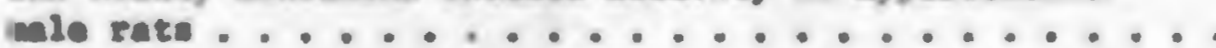

8 Group 3. Relationahlp of urlaory Copae in lovelo (pooled anplen) to artorlel blood presoure (eroup mean) and kidney monoemine oxfdase aetivity in hypartoasive vale rata

9 Group 6. Deletlonship of urinary dopamine Iovelo (peoled saplea) ce arterlal blood prossure (group can) and kldney sobeenite oxidace aetivity in hypertenolve ale rate .........................

10 Mater toble. Nalatloachlp of urinary topanine Iovelo. arterlal bleod presoure and monosalne sxidase activity .

11 Fercent ehanges in urinary dopanine lovele, arterlel bleed presoure, and monomsine oxdlase cerlvity ......

12 Data for the regreseson of bleod preasure on lagartelw bopenthe 
1. Pathway tor the liberation and deatruckion of renin ...

2 Blogynthesin of the catecholnaine. ........... 15

3 Possible pathways for the atibolisn of epinephrine and norepinephrine .................. 10

4 Possible pathvays for the metsbolism of dopanine . . . 20

5 Actfvation and gluorescence spectra of the fluorophore of dopanine .....................

6 Dluorescence Intensity at varying eoncentrations of dopamine ................................ 30

7 ilaster graph. Relationbhips between urinary dopenine lovelo, arterial blood pressure, shi monoasine onidass

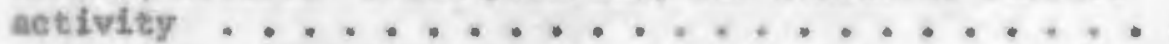

8 Regrasion of arterial blood pressure on logaritbm Copeaine concentration 


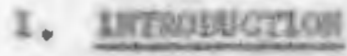

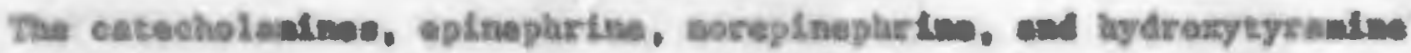

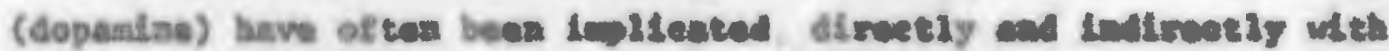
artartal bypertoneLea.

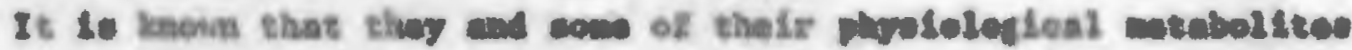

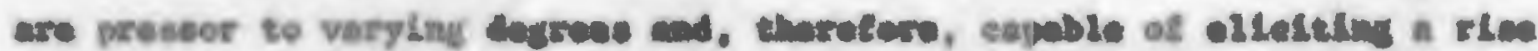

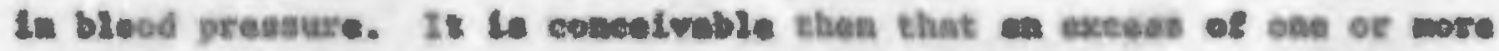

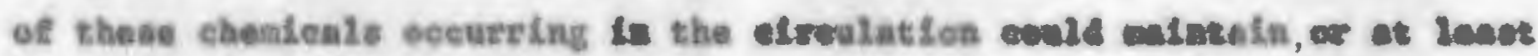
support, a hypertensive condition.

The eatecholanisas, if they are a contributing factor to the byor-

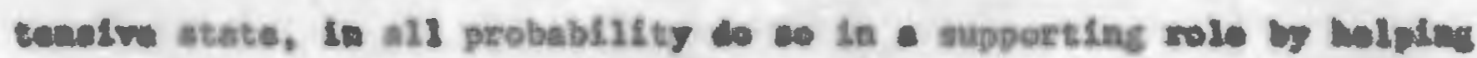

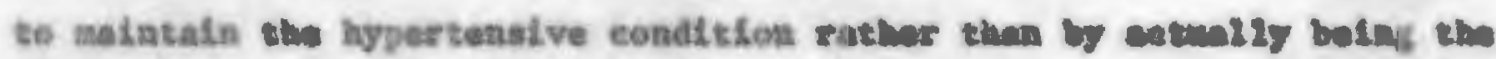
orf ginal eaves.

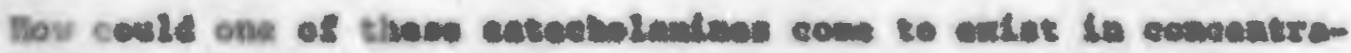

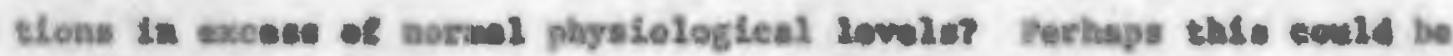

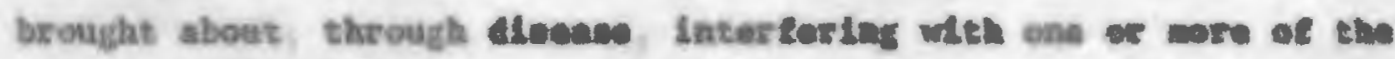

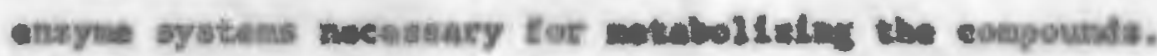

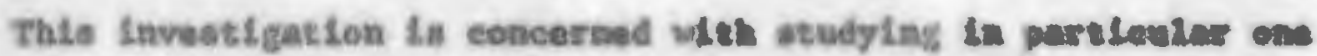

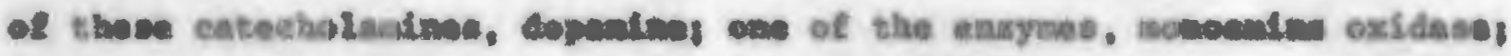

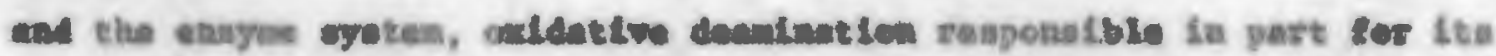
physielogleal Al.apoeltiow.

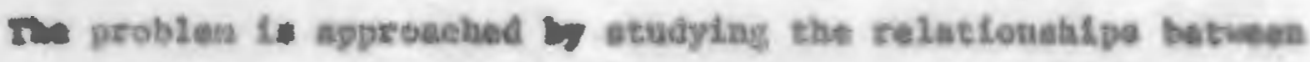

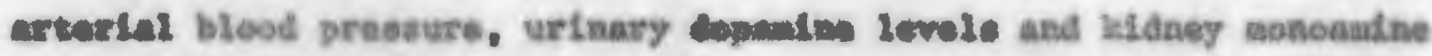

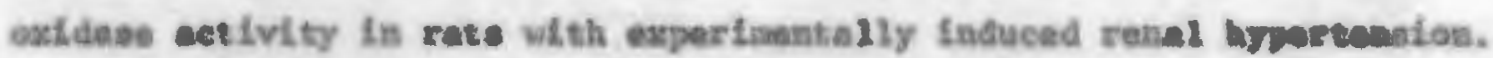




\section{MEVIB⿺辶寸 OF HTERATUL:}

Arteriel hypertenales, thathor so the result of a discace or produced by experimated inatbode, has becone of extrean latorect in the paet twenty-live pare. Ithe rolo of the kidneys, the particlpaten of nervous and endeerine wyoten, and the role of humoral proseor aechailane In eausing and eaintaining hypertenaion how ofoned the roed for may investigations.

Nore ehan ase buadred reare ago Richard solght ade the chearvetea that hypertrophy of the beart, and by Impleation hypertonolon. often vas the rovult of prlenry kleory diecece in ana (eoldring, 1946). Tule guestion in iteale is greatiy debated as kypertenaion io now known to exlot whout apparent prtmary ranal dicase. The mehenden of hyper-

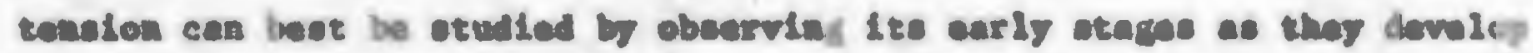
in Indueed experimental hrpertanoton in entenls.

The faet that hyjertcaolon we in sose wey coseclated with reand

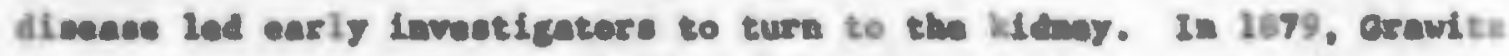
and Ioreal, by partial nephrectovy of rablts. Eemonotrated hypertrophy of the hart wieh thy attributed to hypertension (Goldring, 1046). Peaslor and Heinke In 190 s ropated the procedure in dogs and contirned Grawitz' and Iareal'o work by actually denonatrat ing inereased blood presenure. Alwens in 1909 coetpressed both kidneys by uee of oncoeetero but reported equivocal reculte. Brudgnan and uirose reported negative recults after seute nartial occluolon of the renal arterled (Goldrins. 1946). Unts1 1934 expericarally oustainad hypertenston had not been atcesalu11y produced.

Goldblatt et al. (1934) Indieeted thet in dogs, at Inest, ischenfa Localised to the kidneya lo a auricient condition for the production of 
perafateat2y elevated symtolie bleod presoure. These Inweatigatore vere

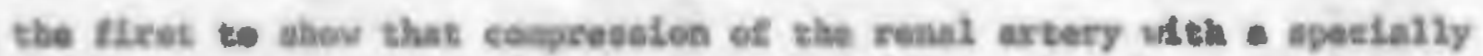

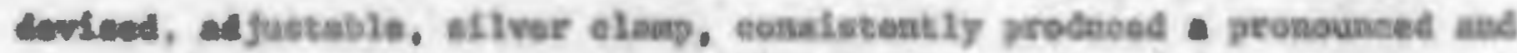

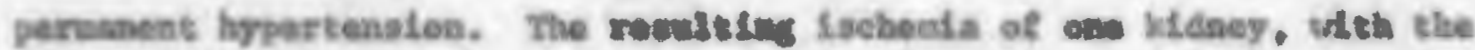
other somalutng horsul, eatused a moderate slevation of blood prescrese wheh eorameed three of four days ales to operatlen. This perninted for onily a short perlod of tiae, vecually about a mosth. Oa the other

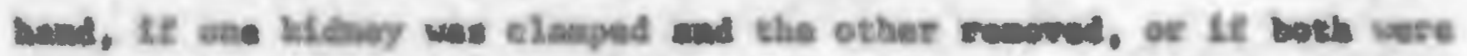

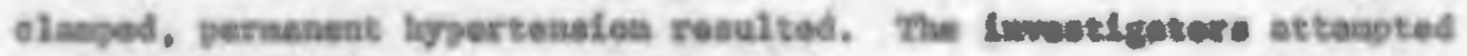

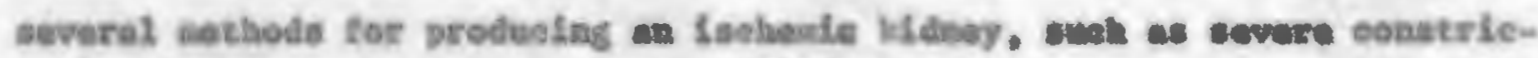
thos of both renal arteries with ohort intorvals betweeh operations, almoat complete constrietion of both reas arterles ud th obort Intervale betven operwilone, and moderate eonatrietion of both rubal arteries. subtained hypertenelos vas denotibtrated in all of these whth the exoeption of the laters, in wich the kypertansion wes sot great enough to be of expertental vales. They ajeo teated tha Sleod prosipure tel-

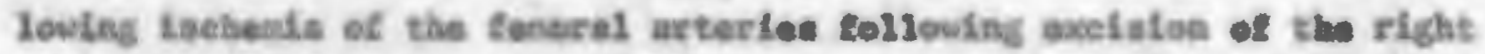
eupareala gland and degeneration of the late supresmal sland. In the above three testa no sigaltienat ehabge in blood preasurs sae observod.

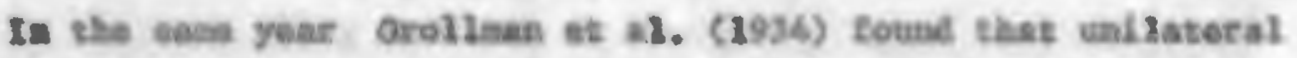

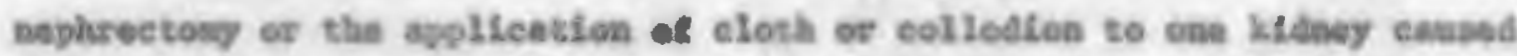
Aypertensioa in a ka11 percentace of aormal rats. The subsepaens resoval of the kldang to waleh the oloth or colloeion had been apniled did not reault in a afouteleant deoline of elevated bloed pressurs. Total aephroctony in enlmal. curviriag long esought tended to ceuse on olove-

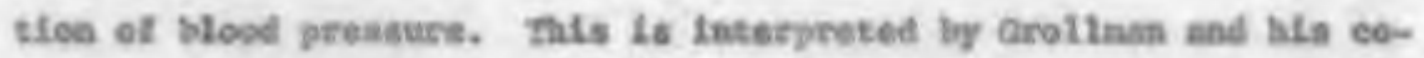

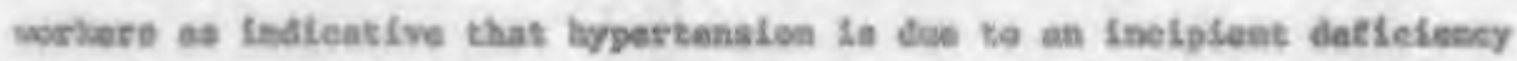


eaused sonow of funetional thoes rather tha by zolsace of a pressor subatasee.

Dury (1930) introchacd a bev method for causlag hyperteasion w

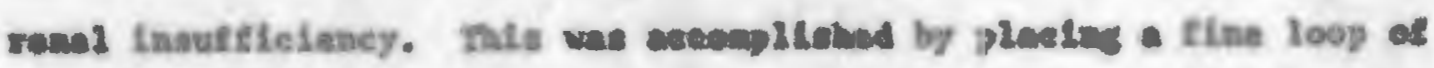

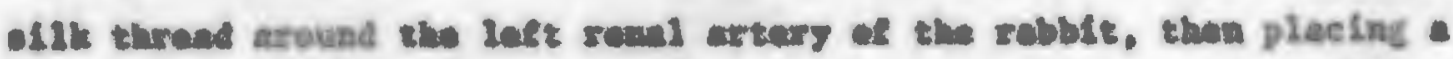

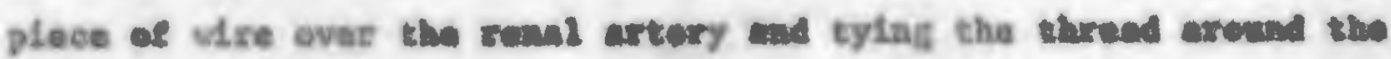

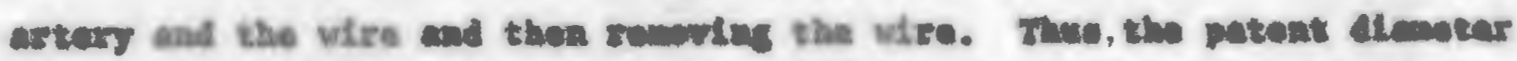
of the artary could be couterelied. Page $(1939 \mathrm{e}, \mathrm{b})$ was ablo to cotalu

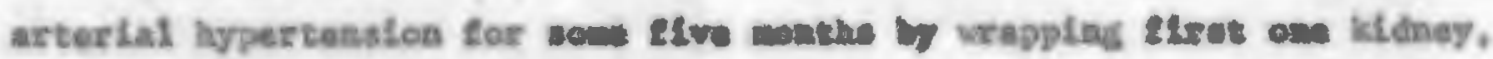
then two velke later the other, In cellophane sabad wh alchol. Grolina (1964) Introduced a Anple procedure tor produetng hypertanston y exposing the Aldnay through the back and applying a Iigature tantly around the three poles of the organ. Itr kyperteneilen alletted by this

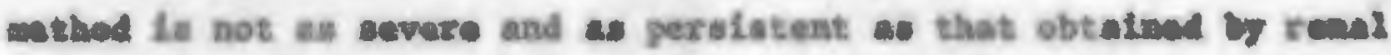
eonetrletion hewever, It dene oldudnate Interforence with the excretery

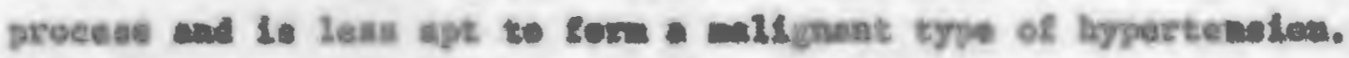

It Le difeieuit to otely hyperteasive cuthads without innodintely

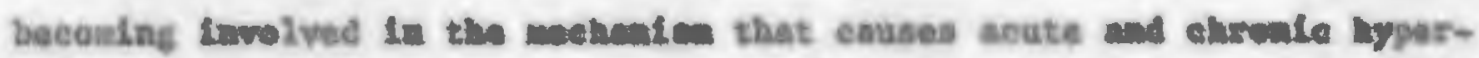

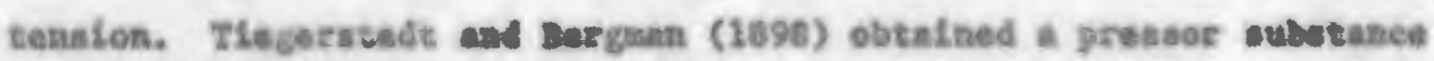

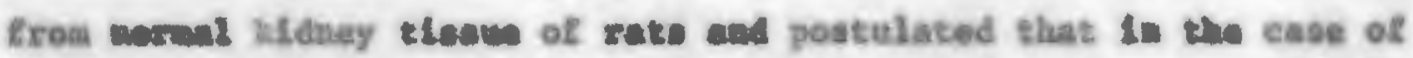

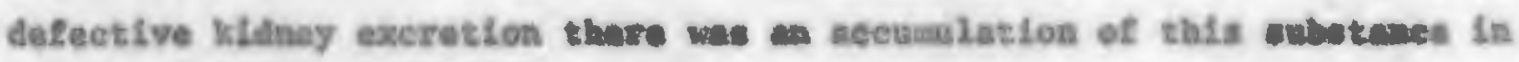
th oled. Many believe that the Intsial easse of hypertensten sollowing eoaetrietion of the kidney in wo to a releace of a substanes from tha kidney. Mateh watle in Ituelf to not preaser in action way be the precursos; or better at LI. the aetivator of a preanor rubotance. Tha

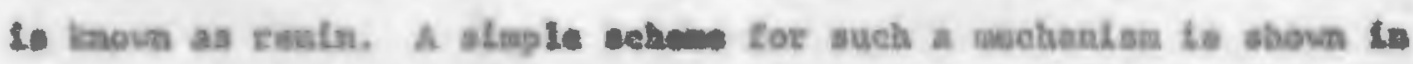
etare 1 
8.

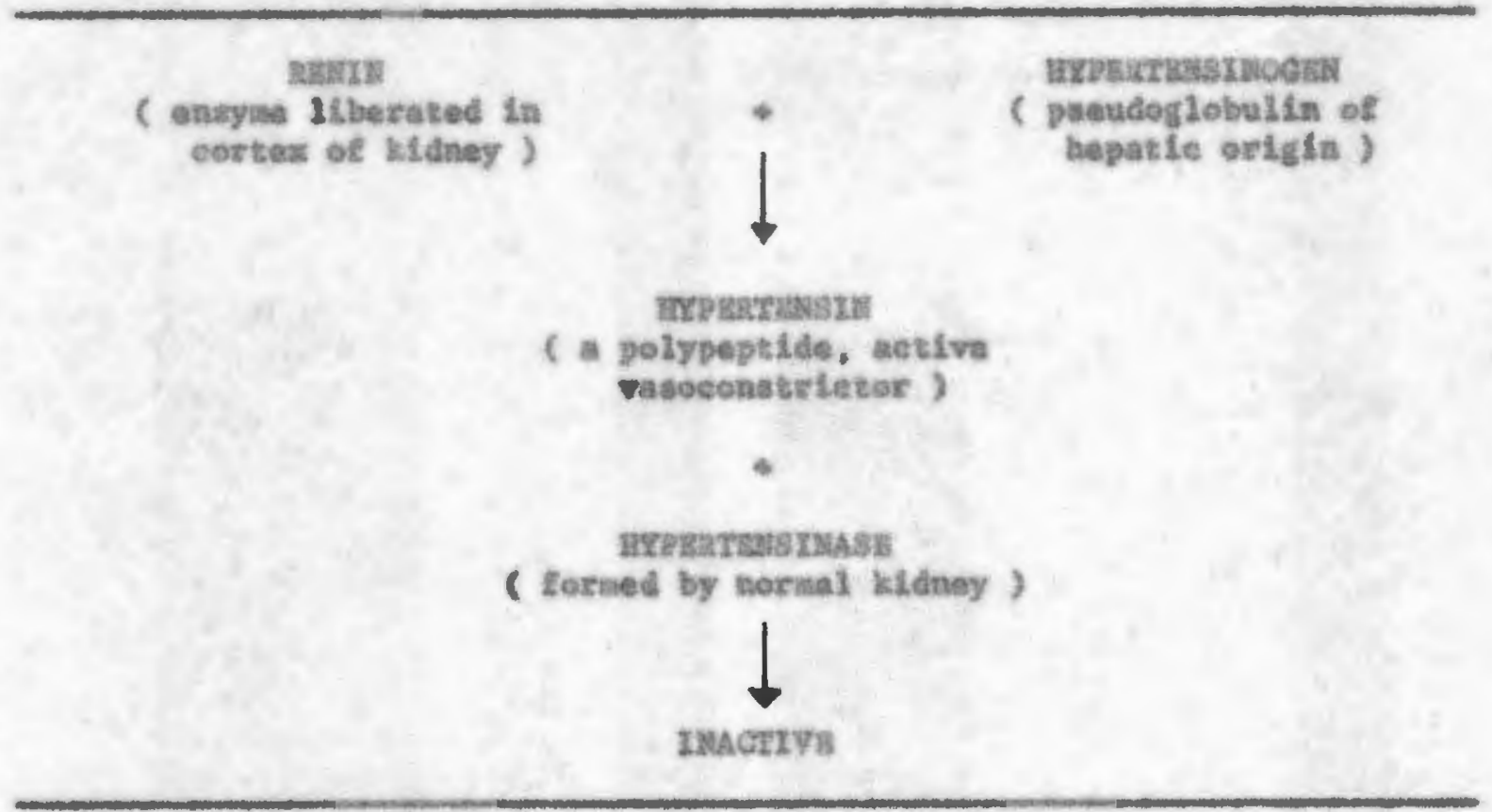

Mg. 1. Fathary for the liberation and deatruetion of rendn (Beat and Taylor, 1955) 
Aceording to lloudobre and bevendes $(1962)$ renin Lo a protala ensyre produead in the kidney which Intersete with a blood globulin (hypertenafnogen) to forn an active vasoconatrictor (hypertesein) which by lto action on the peripheral vesels and on the heart cauces a rleo In hloed pressure. Mononder (1536) atates that the renetlon to in all probability ensynetie and has an optimal pll of 7.5 -8.5 and an optinal teaperature of $37-39^{\circ} \mathrm{C}$.

The Anvoutigations of Collino (1936) seennd to Itror the theory of a telense of a preseor principle. His studies alininated the poaolbilfty thet a nervous roflex originating fros the hlowre aflected the vasobotor apperatus, which thereby pleyed a part in the origin of experimontal lypartension, Is demonatreting that hyporteneion was proeueed when the kidneys were couplotoly coservated. Houssey and Jacuin! (1938)

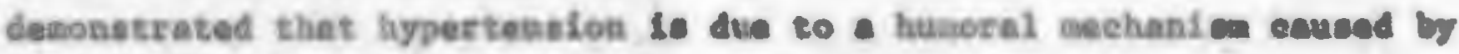
- preasor subetanee Ln the bleed known as anglotonin or hypertenoln. This hyportensin proved to be the recult of a ehenieal reaetion botwoon a paudoglobulin of the plasen and a cortaln cubotanee inota an ranin to be tound in the kidnay. Later, st wa proved by Page at al. (1941) that renin ba the propertice of a proteolycie enayas. Sepierstein ot al. (1941) grobented the eoneept that the blood of the norcal aninel vith normal julae prebcure containe ectivator subetance but no roala, vhereas blood taloen alter henorrhnge when the pulse pressure ma be low, contalns deanstrable eavounts of renin-1ike oubatanes.

Not ell investigntors hav been in aceord as to that mbatance, if any, is released ints the blood durlng byoertension. Grollean end liule (1935) observing that hymetondon peroisted even after bilateral nsphrnetong, postulated that hysartenefon vas due to reinoval of funetional tsaue 
rathor than to rolease of preseor abotance. Orollaen (1942), honsver,

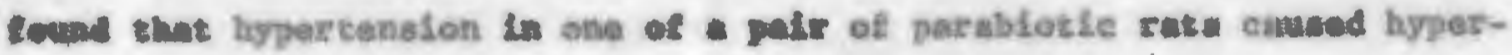

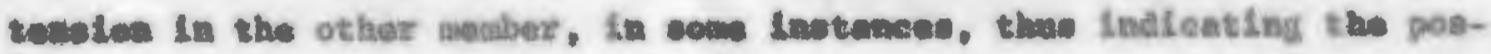

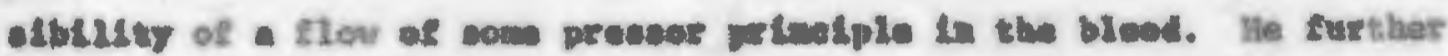

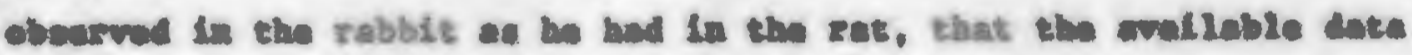

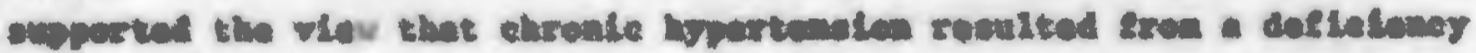

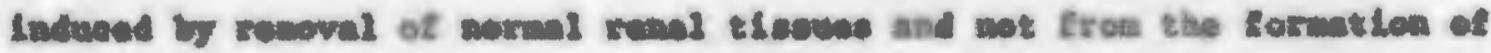

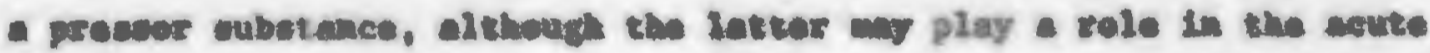

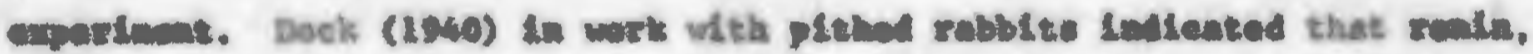

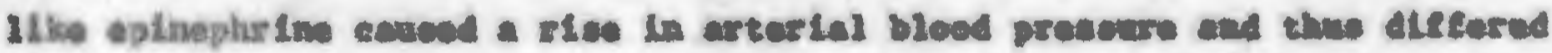

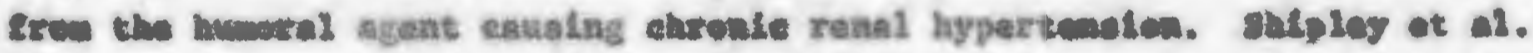

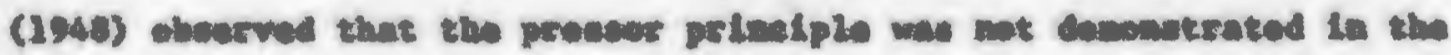

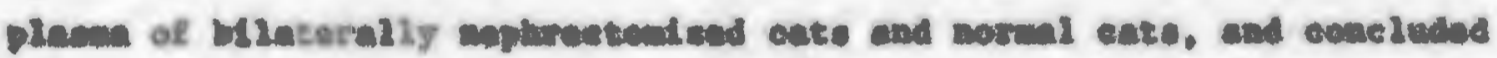

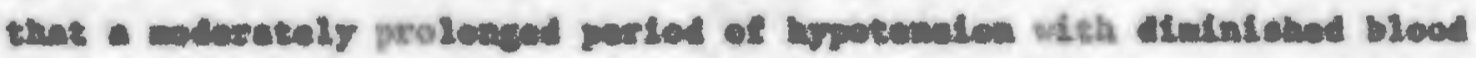

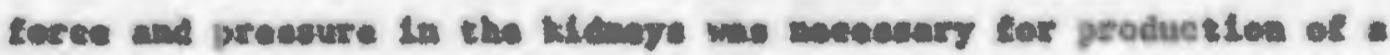

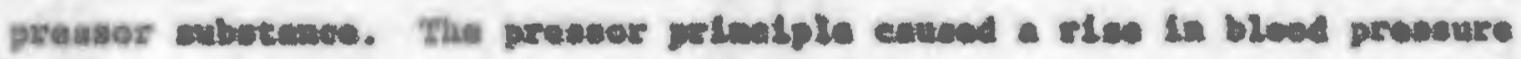

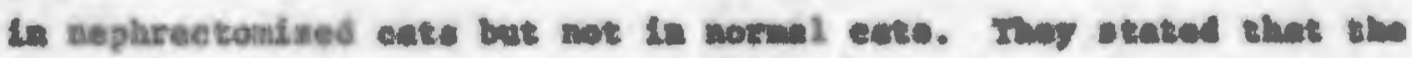

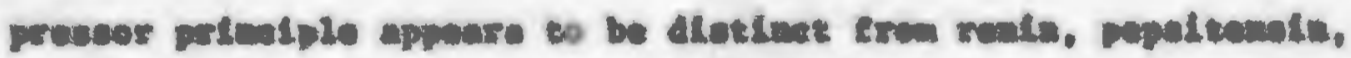

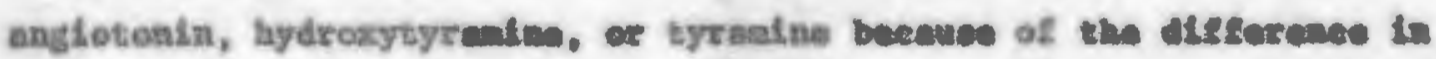

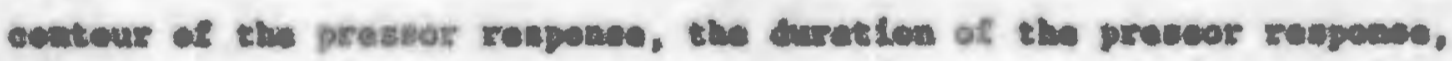

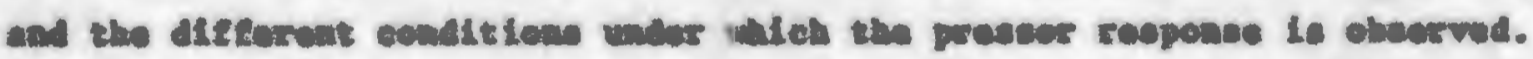

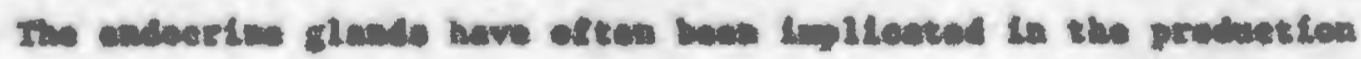

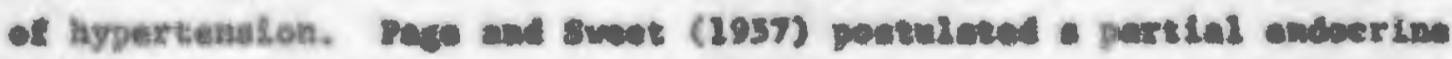

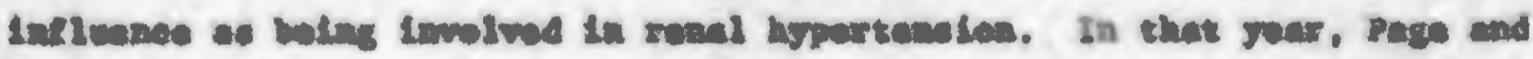

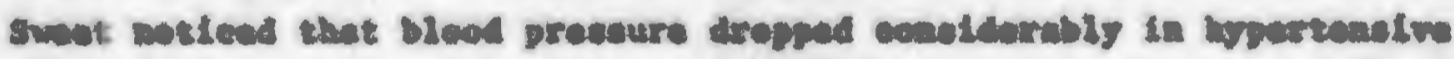

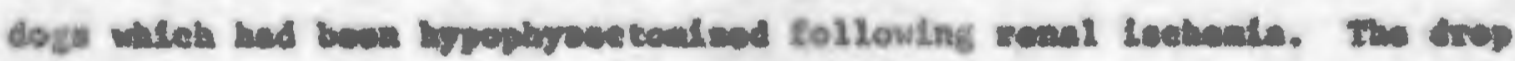

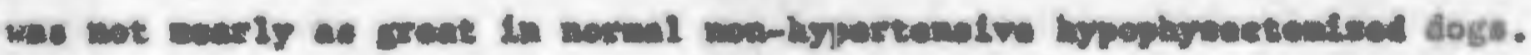


12.

raw belleved the eftect of hypophysectomy sa hypertenafve doge an indireet one, and it was postulated that the response of the blood vassele to ehenfeel sties 1 . Iron the kd dneys vith eonatrieted renal arturios vas reduesd. Thin was atcributed to the lack of aecretions of the adrenal and thyrold glands.

Page (1939s) found thes unilateral edranalectony ceused a drop in pressure in hypertenalve rat. wherean renoval of the other adrenal gland. - month later, caused an even greater drop In presoure.

Bessinger and tialierifn (1940) tound that the condition of adrena1 inourfleiency did not eppear to reduee the ronin concentration of the Lscheale kidney, but appeared to lever renln returs to the contralateral non-eonstrieted kidney. They furthar tound that the abcance of both

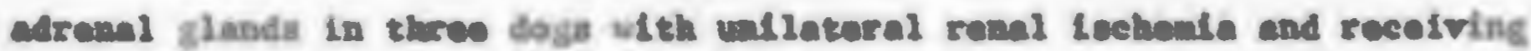
malntatnanee dones of desouryeorticosterone ccotate (DCA) did not alter of

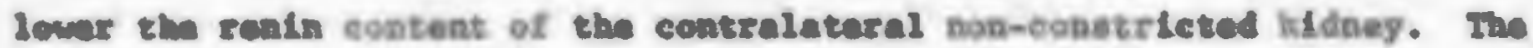

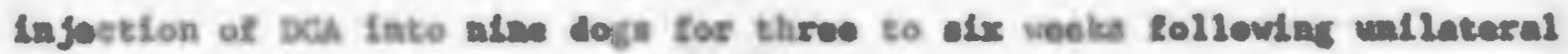
ronal iecheela aigniticantiy decreaned the extractable realn from the conatrleted lidaey but did not change of altar the renin concentration of the eontralateral kidney. The renin wall olgalfleasty decreased in the kidneys of three normal dog roceiving DCA Ror IIve weelcs.

InII and hall (1949) obearved that blood proeoure of rate rendered Agpartenalve by trantsent with DCA contitued to ries following total neplureetoby. Typertenaton of this type is not dependeat upon the adrenal nechanise $t o r$ ite malatafnance and is not a consequenee of ronal vascular daesge, which it a Iator dovelopent.

Mason at in. (1950) fndicated a possible sole of tho adrcands in ehronie hypertensloa. They found that DCA, one of the bormonee of the 
adrenal cortex, torreeted for soes of the deffefenefes caused ty alrenaleetony. It elfelted funetional and struetural ehanges characteriatie of kypertenelve viscutar Alease. The blood prossure of undlateral nophree-

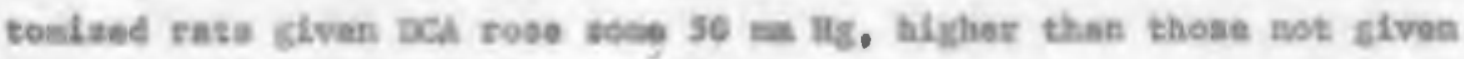
the haraobe.

Goldblate (1951) Lound that after bilaterni adronslectory as kyper-

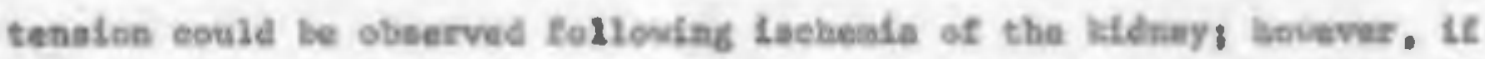
eortin was adsisisterad Aypertensien resulted. It seesed thet hypertenainogen vas reduced after the adrenalectomy. The eortieal hermone oeens to be needed for the produetion of the subetrate upen matel renia acts.

frandt et al. (1551) Eound that alt hypertension in the rat peroloted for at least tour veaks aftor adrenalectoay. Dephrectoay did not abolish sult hyportension. These reaules vere faterprebed ac saening that hypertenaioa developing troa mit aladntetration is dependent directly on a dsturbase of eluid distribution and not madiated thre the kidney or adrenale, such as vas indicated by Goldblatt (1951).

Bery and Waluerin (1953) otate that the only ondoerines wheh apjeas to be involved in retal hypertenalve procesees are the kypophysis and adrenal oortex. They atate that ranin, by otimulating the pitultary, Indirecty produces a acretion of DCA from the adrenel eortex which in turn eaused a deerase in reas renin coneentratiob. Thlo cecrease 10 aessured on the besis of absence of increaved renin secretion. Flonever, Dos adninistration does not sees to hinder aypertension, but on the other hand weans es onanes $\mathrm{Lt}$.

Haysed ot al. (1955) obearved thet the pleane level of hyper-

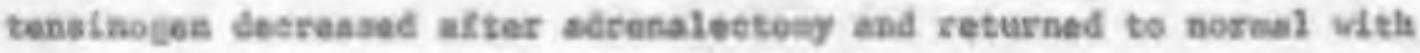


13.

sdeinfetration of eperfeal extracts. Cortiane and Adcehoesetieotropie

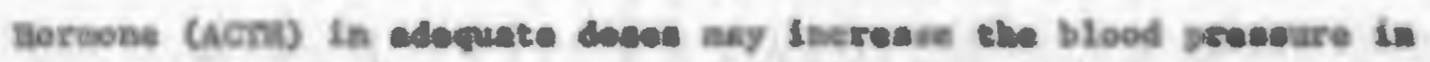

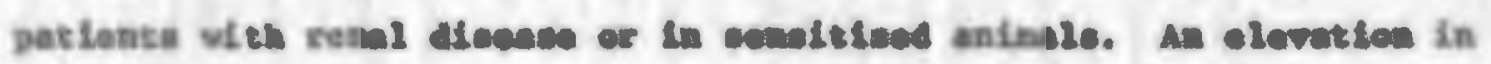

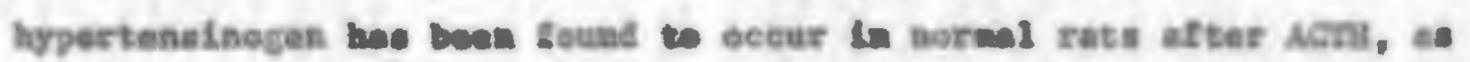
wall oe eotrogens, hwo been adalniatered. The Inecenee in hrpertensigogen -vaerwed after adefnistratios of ACm was prasumably mediated by the adrenale, atces it wee not depeted in exporieente os adrenalectonised

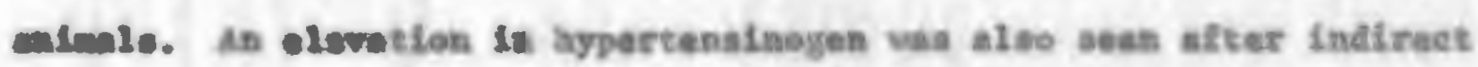

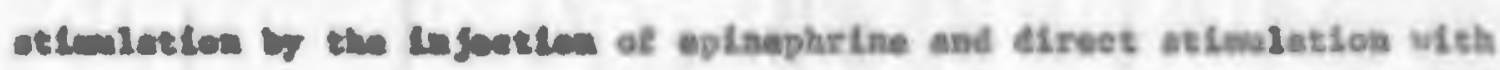
cortisone, but not wed bas.

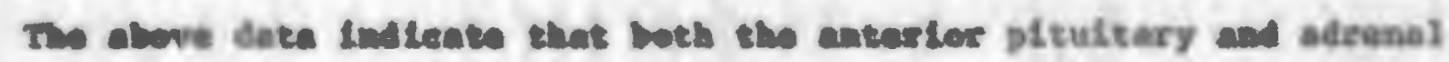
eorta play con role in ebo bypartenatve aschoulca elthough tholr rolea

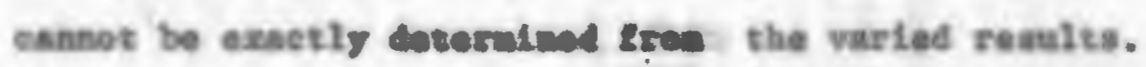

One can acoum wieh reasoable probability that renis by ds: aetivation of hypertensin to partelly reoponsible for hypercension in the acute experineat; however, the beseeal theory of tho cause and

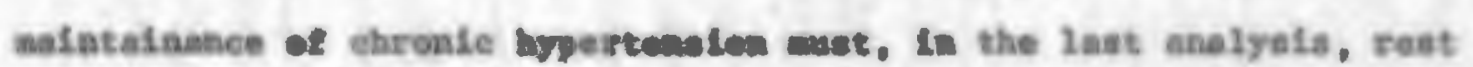
upan the demenotration of the oceurtesee of vasopreator gusstaneed other thee renfe in the perijharal bleod, as rentn eanot be deanestrate in ehronle bypertenston. podi wat not tound is tho peripbeiral bloed of

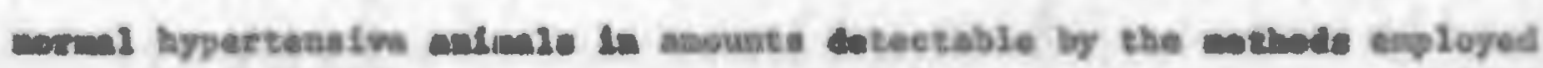

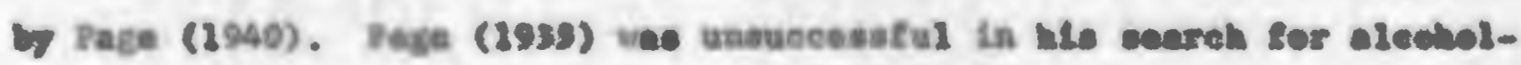

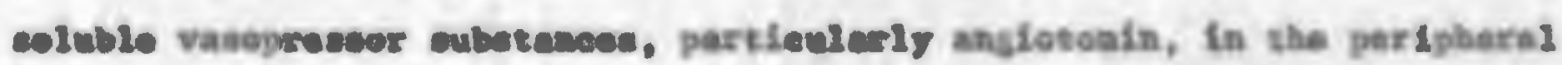
blect of hypertenstve aintende.

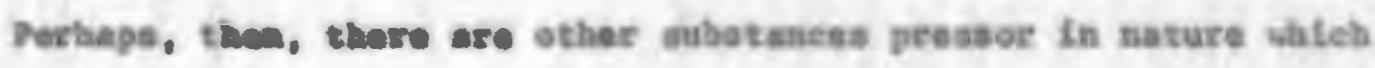
are raoponesble toe the nafntafnate of hypertensfon. The precursors of

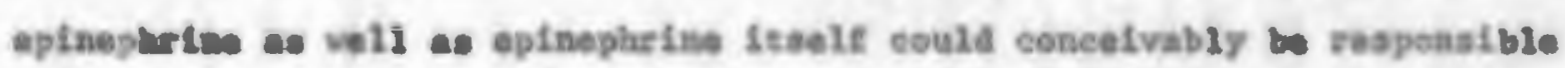
for the eecurveace of the hypertenalw stese at they are all lanove to 
possease pressor projprties. Bhould there be interfarence with the aietalialles of thase compounde an excese of on or bore alght occur in the peripheral elreulation.

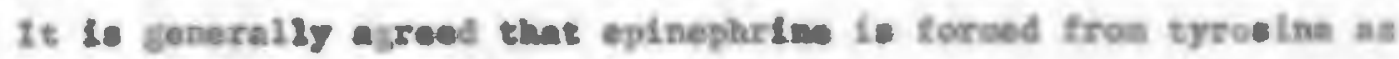
chow in 21 gure $\mathbf{Z}$.

The firet three eompounds, phenylalonim, tyroaine, and 3,4-dihydronty-

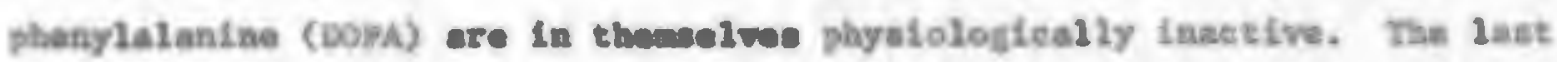
three coapounds, hydroxytyranine (dopaine), noreplnephrine, and epinephrine roprecent the aetre eatedrolcalme.

The eirst iportant otep is the cocerberiation of DopA to sopanine

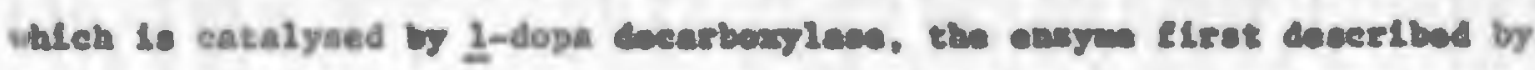

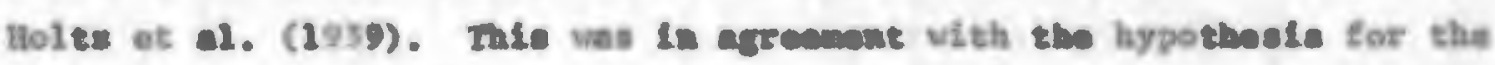

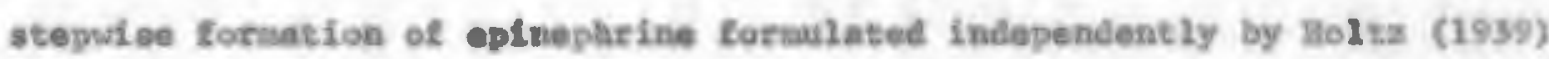
and Blesehiso (1939).

The first deslulte evideace in support of this sal given by Dusis et a1. (1955,56) when they Ineubated rallosetive $\left(\alpha^{14} \mathrm{c}\right)$ dopa with homogenates of bovine adrenal medu1lary extrects and Isolated redioactive dopemine and noreplmephrine. Further evidenee tor the sequence is rese

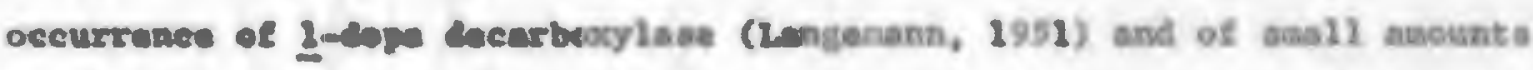
of dopande (ooden11, 1951; thephord and Vest, 1953a) in the suprarenal monl2e. and the desonatration that both in vivo and in vitro induliers

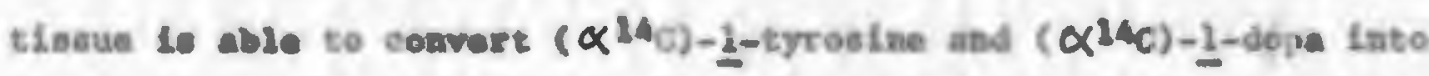

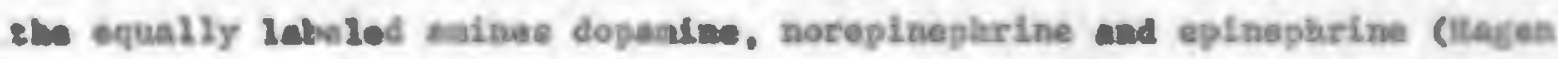
and Veleh, 1056, Goodn12 and Kirahuer, 1957, Kirshner and Goodel1, 2956, Loopar and velentriand, 1956). Prier to 1957, the quantitative mosmuresent of eatecholenines vas

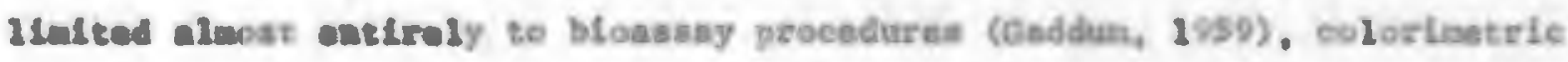




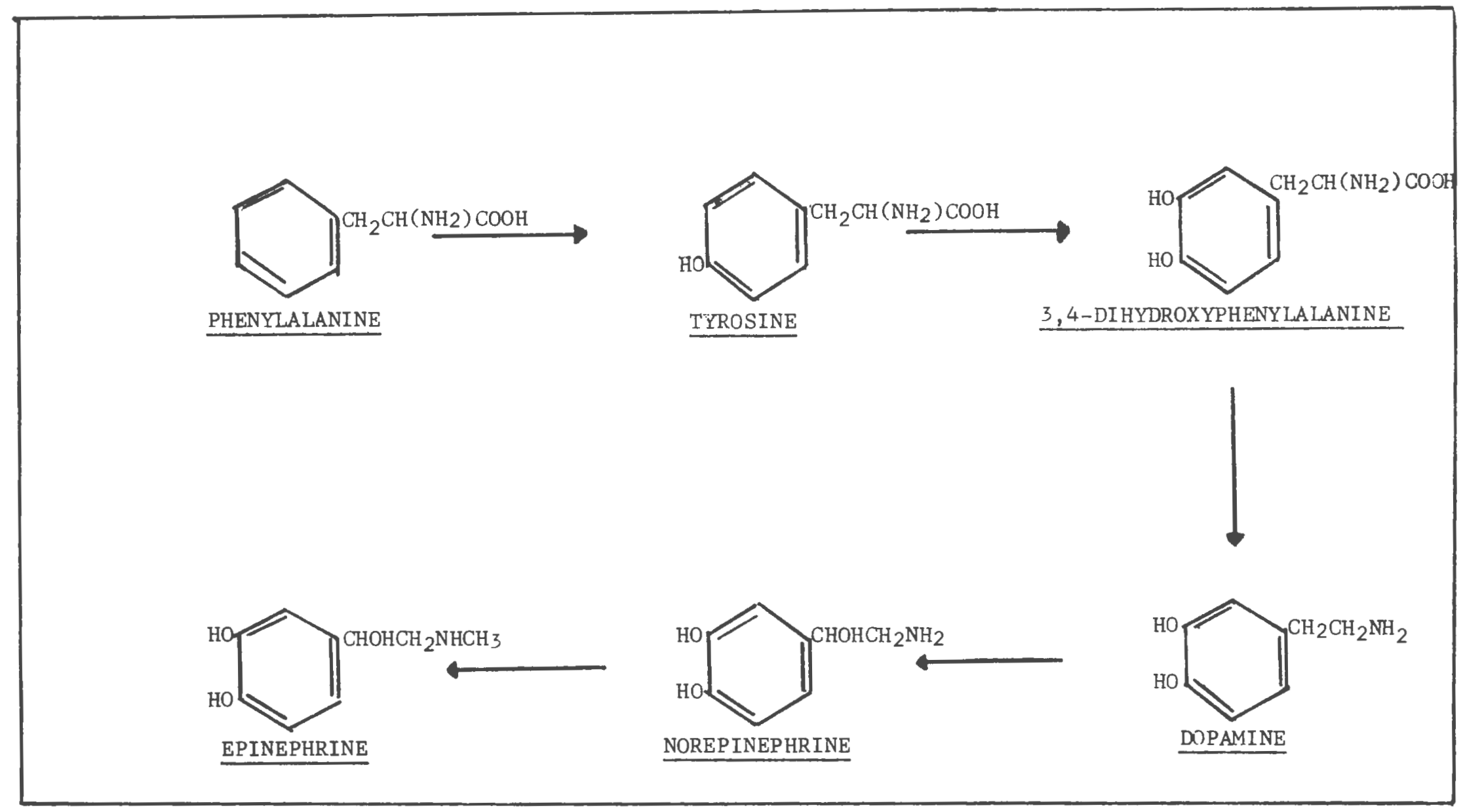

Fig. 2. Biosynthesis of the catecholamines. 


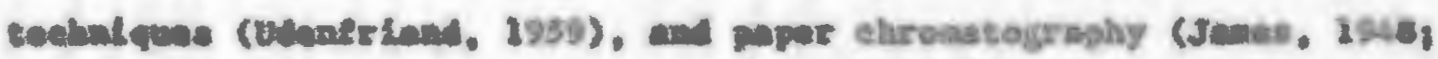

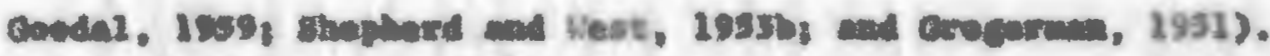

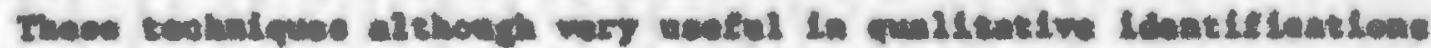

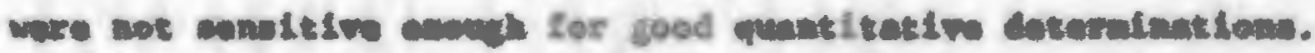

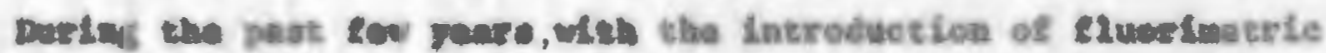

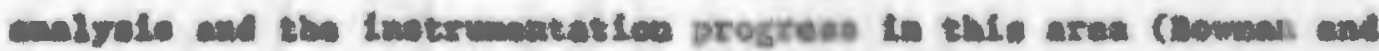

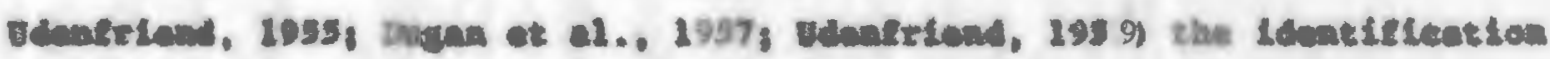
of the preaceore and the pothry for the fornation of epinoplirine has

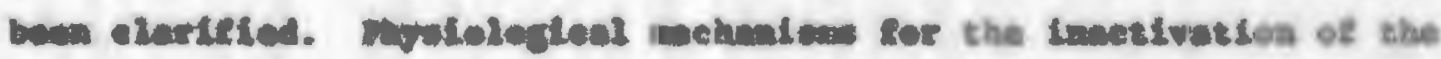

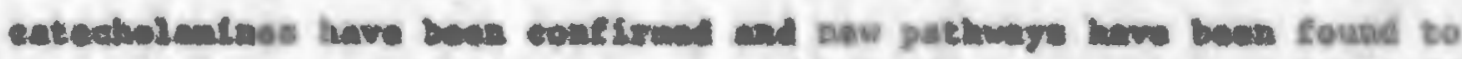

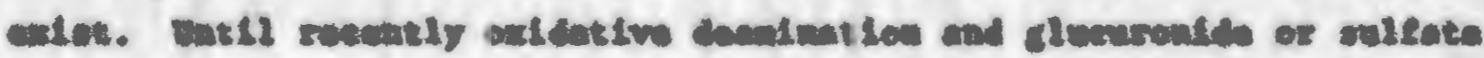

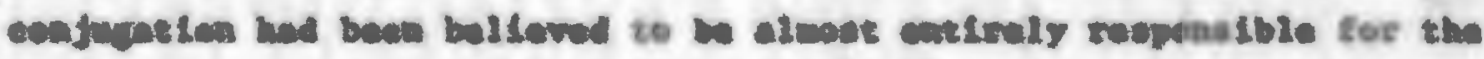

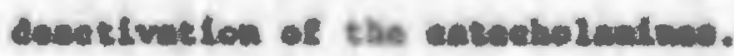

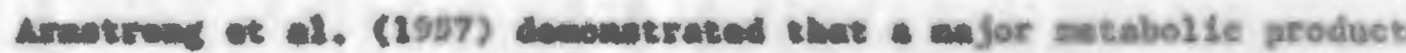
of noregineplurine in and Io 3-ibethoxy-h-hydroxyandolle acL. Aselrod

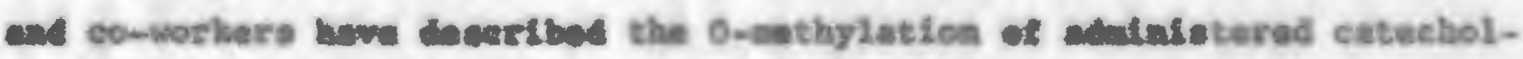

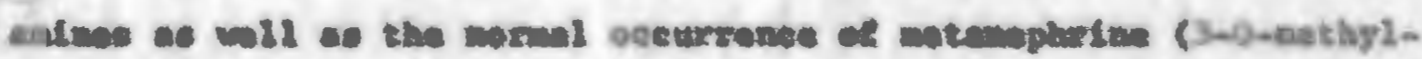

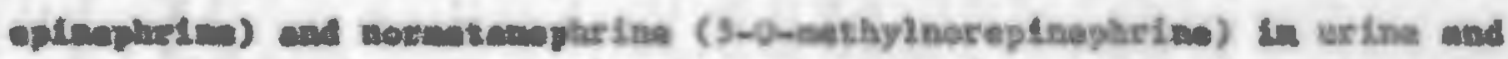

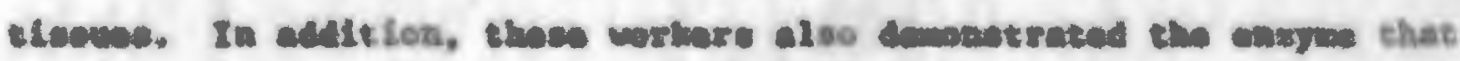

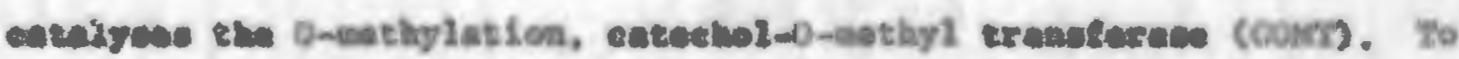

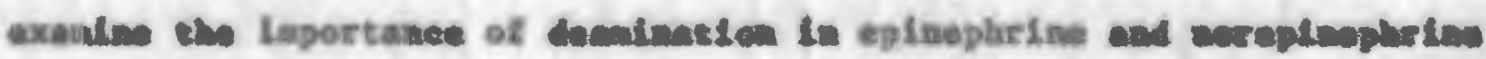

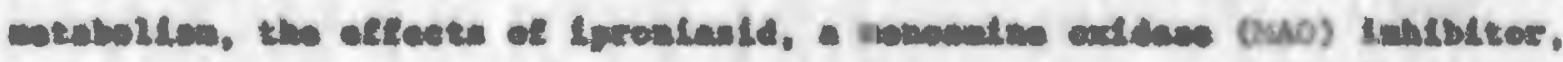

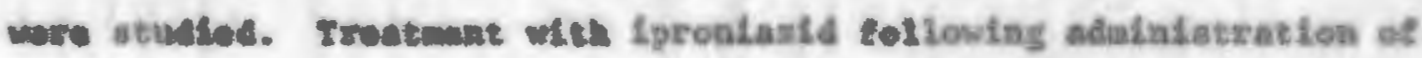

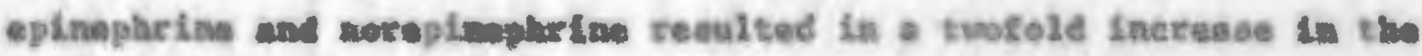

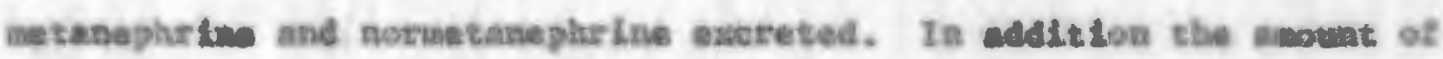
3-eethory-4-hydroxywandeliq eale exereted was mazkediy reduetd. Thon

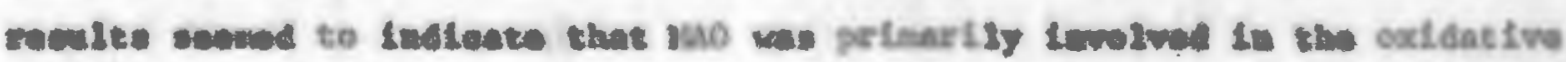




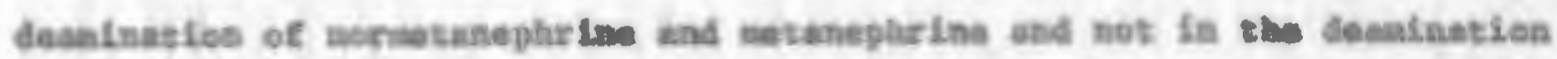

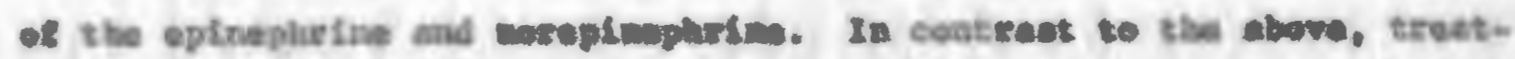

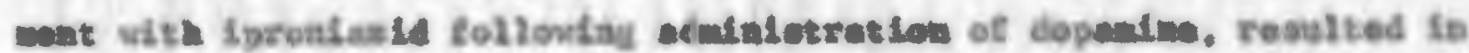

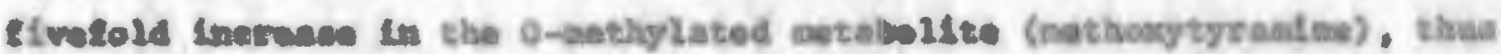

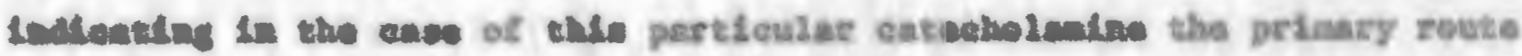

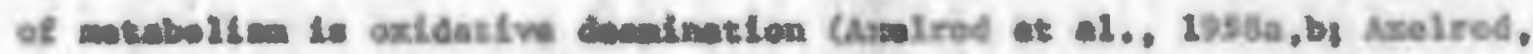
1937; Arolred, 1995).

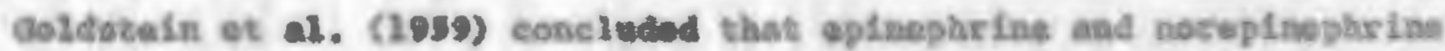
uadargo D-aethylntion whbout deanias Los sad vore orereted meinly as

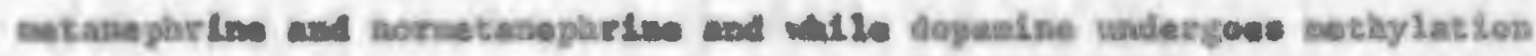

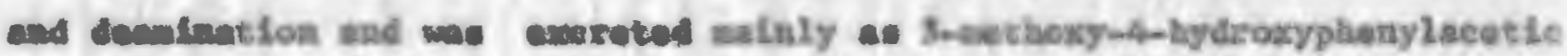

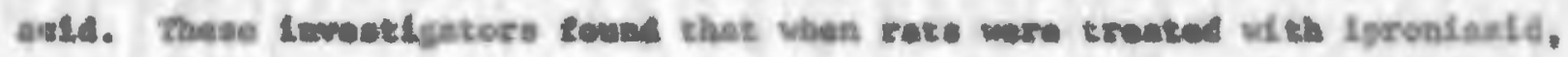

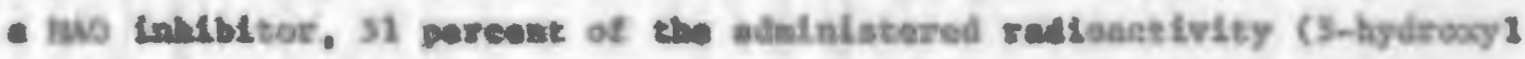

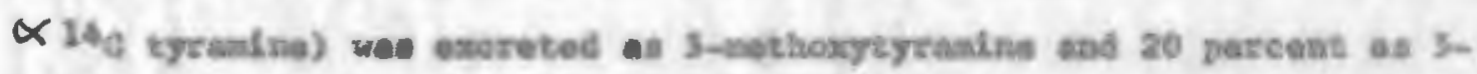

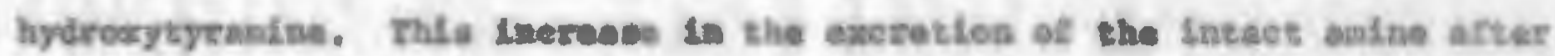

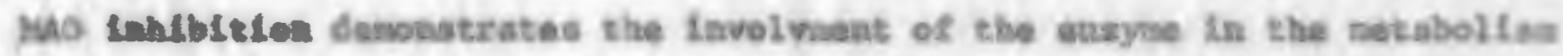

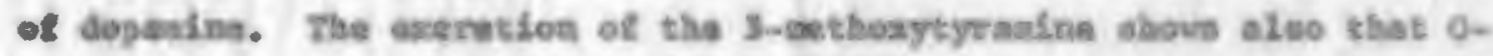
othylation coes oesur to cho intact alne.

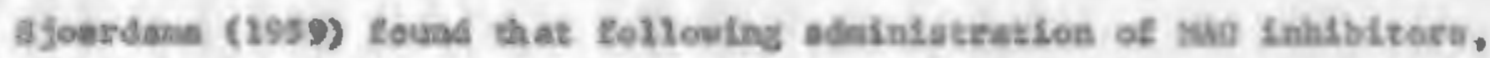

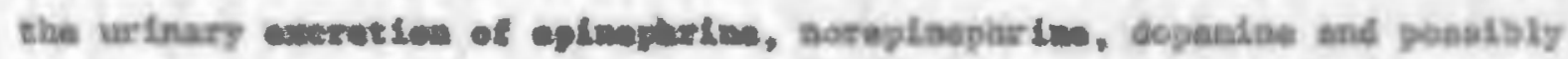

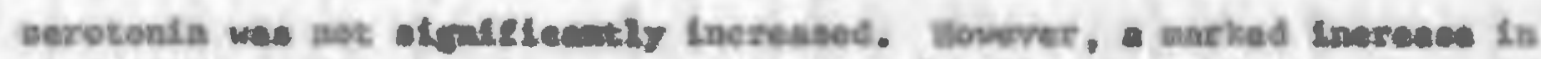

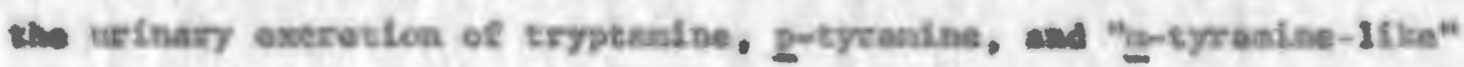

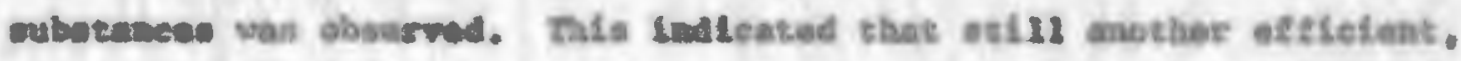

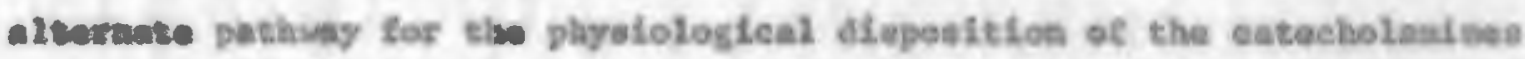

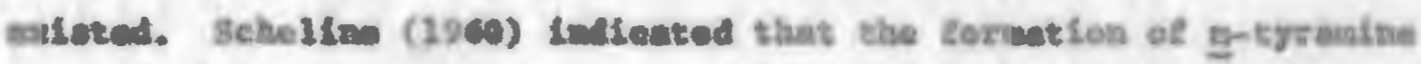
subotanoev whe posoible, by demonatracing that debydroxylation of ariantie eoupounds does oecur in the calmal body. 


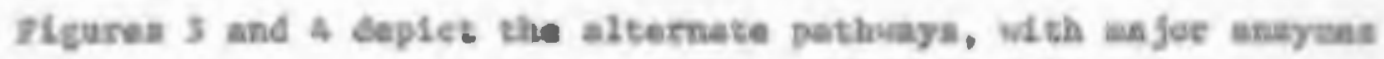
Invived, tor the phyaiological inaetivation of epinephrine, norepinepluriae. and depastne.

Infotset lon rolating cetecholsaine leweis to octerial hypertenafon has bee oparse. Yoe Euler (1956) Lound that the norepinephrine levels sere norten in 04 percent of 418 mypertenaive patienta tested. In the reasialns 15 percent none colblted wat he ealled signifleast incresses. Manger et a1. (1559) denonitrated that efreulating catecholataln Levels were sornal in hypertenslon. Weld-inlherbe and Bone (2957) reported an appeosinately tuofold increase in oplnephrine and nosepinephef mo and a

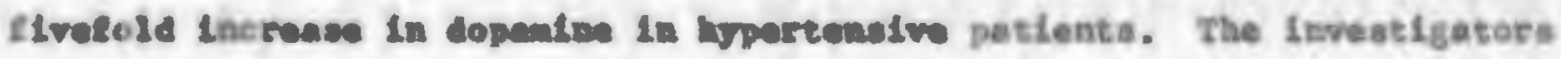
alco pointed out that the excretion of dopasafne vas extremely variabio. sehroeder and Acan (1941) damotrated that the injection of a preparation of kyroeinase to sultoble doses isto rats and doge eachibielng romal bypertension reculted is a reduntion of bleod presases. Furtheroore, thy oberved a discarence in the reoponse of nornel animals, their bleod preseurs bing loes of not at all afsected. The aughora state that although the posibility exlote that the hypotensive oction of this onky=e is a nonavalfle one, the nost probable eqlanation of the phenomenon is that coes wubatance present in tha hypertenidve otate in altarnd. secause tyrosinase coto only on coupounds containing a mono- or Al-hydraxybenteae etructure

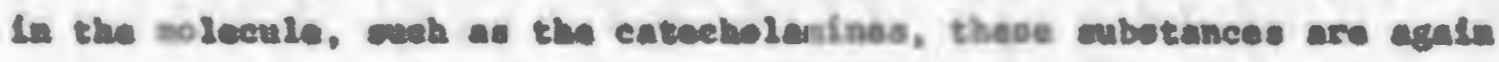
findleated fis the tryartenatve procese.

The ldidney oell1 recolves extenatve support as the producer of prececer materiale in bypertenston.

Bing (1961) reported that the produetion of a prenoor nubstase preaunably dopanine by decarboxylation of Doph oceurted in extracts of 


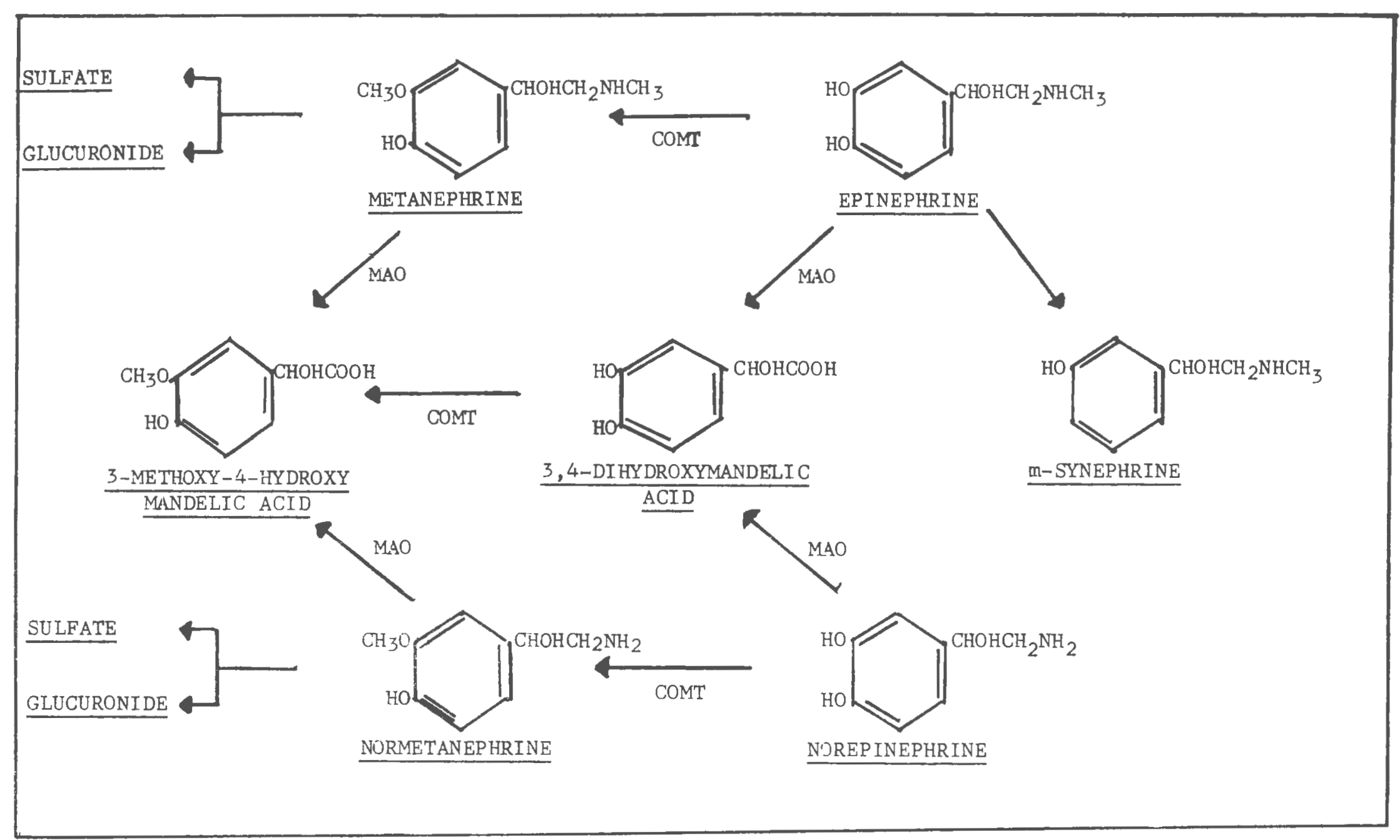

Fig. 3. Possible pathways for the metabolism of epinephrine and norepinephrine. 


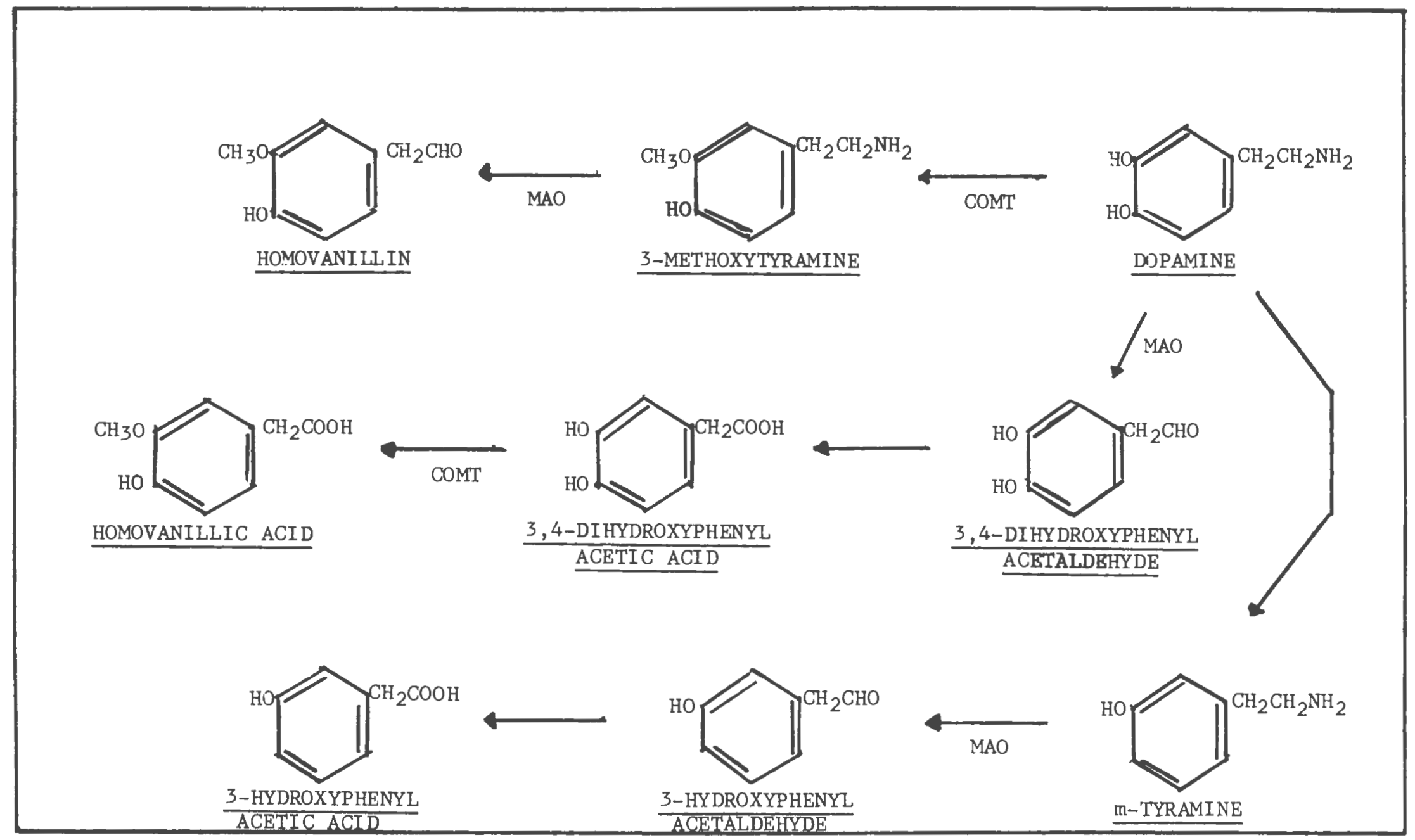

Fig. 4. Possible pathways for the metabolism of dopamine. 
gulnen pif kidneys Ineutated ender anarobie coatitions. He woted shat a sind ler reastios sook place In the Lecbeale cat'a Midney perfubed whth bloed consalning DoeA. Ae a conkrol elns aloo perfubed liver and at of

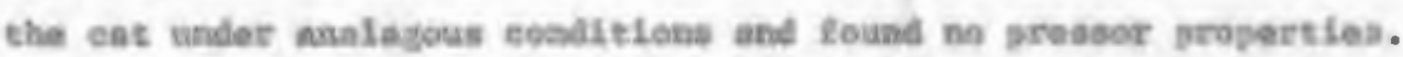
Sehroedar (1942) premented evidenea that deastnatlon but bot decarbodyletion of certain elno acide is Ineosplete in kidnoya detiefene in their

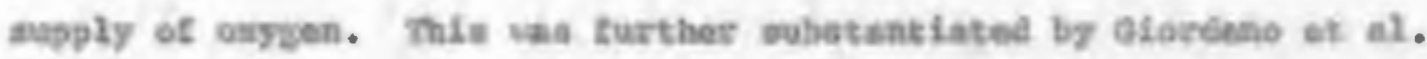

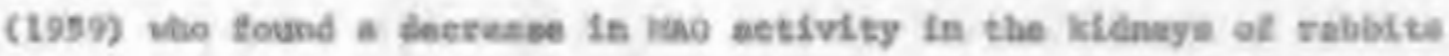
wheh vere zendered hypertensive by renal ischenta. Bitice doesthoxylation of animo gelde leads in eany inetances to the Rornation of greabot andres, and oxtdotive deealnation is necesnary for the inactivation of

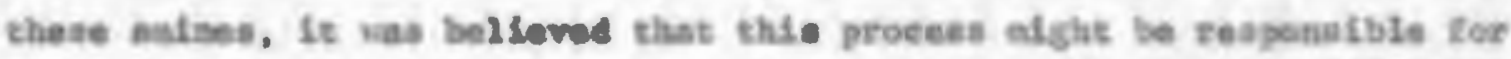
woce varleties of arterlal bypercenalou.

Maseluke (1932) desonstrated that No oxidimes dopaelne at a raptd rate as it loeks she $\beta$-laydroxyl grous possanind by the othet catecholenfnes. Hageh and Neleh (1955) indieated shat mo prakerensialiy atzecked dopanine. Dopealne agpearo then to bave a tremondous afeinizy tor way and therefore alght be the primary physfelegleal vabatrate tor the enarge (Elaschloo, 1952).

In the esose of reand fasurfielency, the prenence of eostinaing decartooglation Mthout deaninatice could lead to a bulldup of dopanine which oouid not be metabolized.

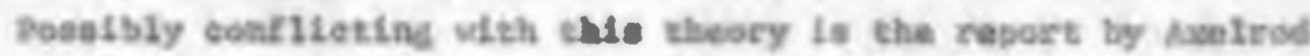
and Doaehiek (39se) which atated that estechol-0-eothyl trassterasa aetivity is the ret is che greateat in the liver and kidney. It usa

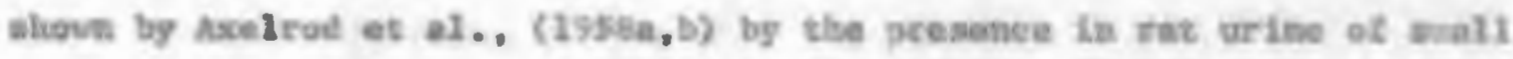

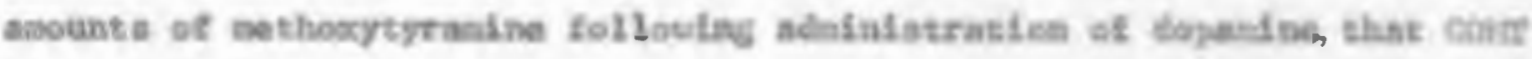


wh11 nesbollse copanlne to some extent.

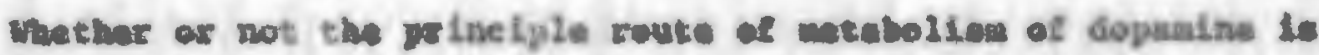

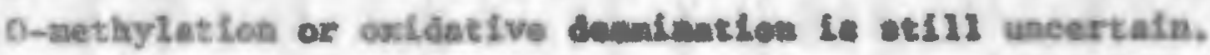

A controverofal isow at the proveat tive to whleh enayme, covr or wo, Le nore important in the ntabolias of the cateohelanines. Does

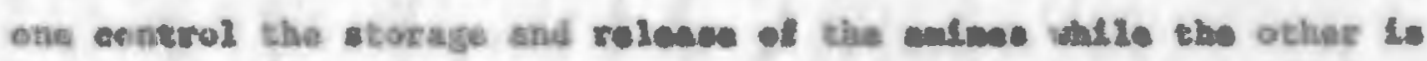

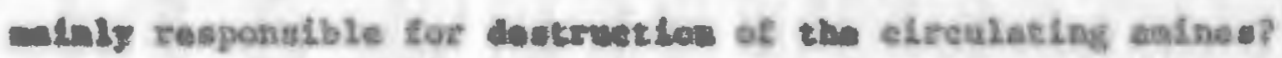

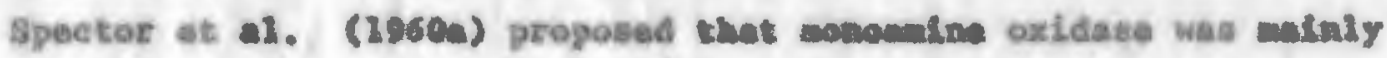

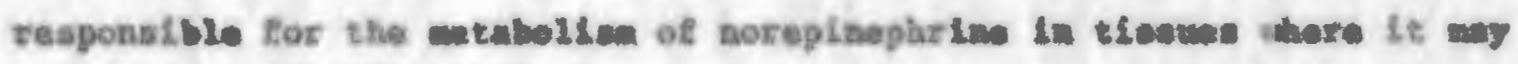

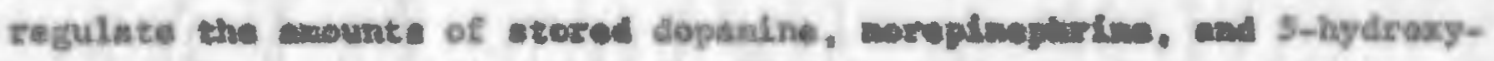
exyptand ne.

Crout at at. (1250) proposed tha hylperhole that we ecte on

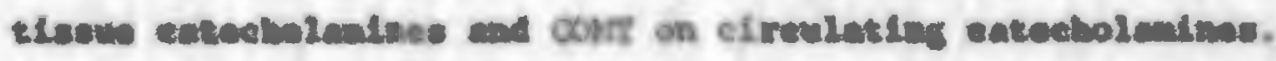

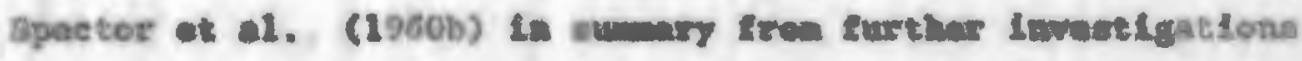

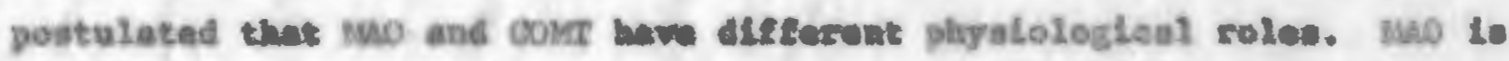

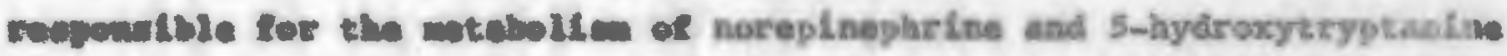

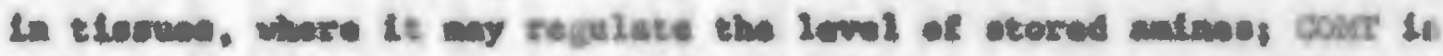

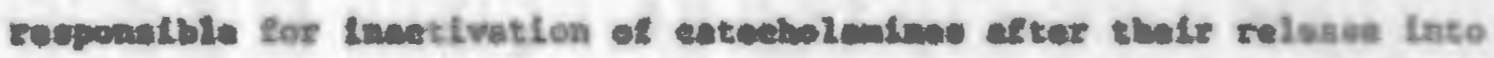
elreviets.

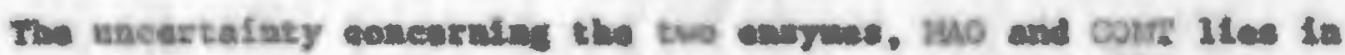

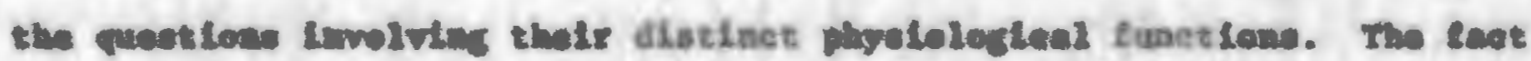

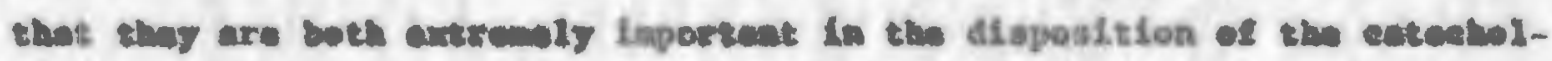
andere is cortede.

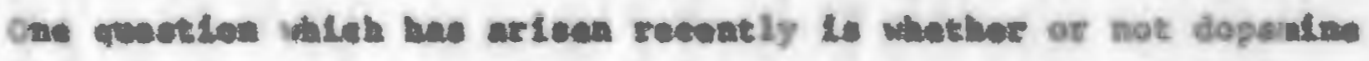
1. pinsecor.

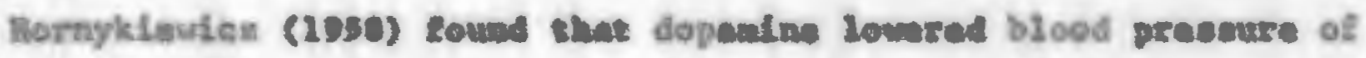

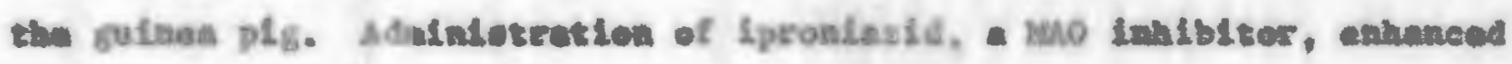


this hypotensive alfeet. Burn and Rand (2958) found that dopamine causes - Eell in the bleod presoure of the guinea plg and cat under urethan anesthea1. When the sulnas $\mathrm{pls}$ and cet are first ingeted with recerplea,

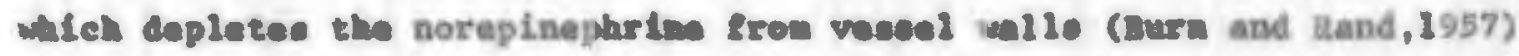
depanine then bacone preacor. Opon the intravanou Infusion of noreplnephrine the deprescor action of dopemine returned. The hypotensive ectlon of dopasine sean to be quatitative in nature. It does not appear te be a quoticn of mother or not dopanine is praceor or dejrescer but rathor of coapetitive antagonien. A siva amount of cloparine competes Wth norepinepletin for receptor altee, fuet enough to intertere with

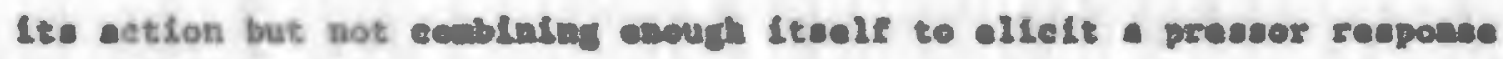
( Dura and Rand, 1958).

Borowita of el. (2960) demonstrated that the Intravenous injection of dopend into man alleited a riee in arterlal blood preseure,

Proguad ot al. (1051) chowed dopasine to be proseor in the rat. After an Infoetion of DORA an inerease in blood gresoure was observod. This we oxplated on the bate of lnereased dopentne produetion by beartomblation of the DopA. Following the adminiotration of a dopa decerboxylase indbltor the preseor reeponoe was lost.

Tresent evicones seen to Indicate that dopanine is a pressor

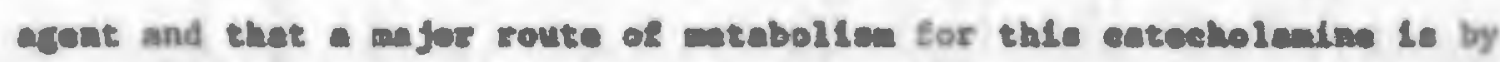
oxidetive deanination. 


\section{Iunstestion}

\section{4. orrectres}

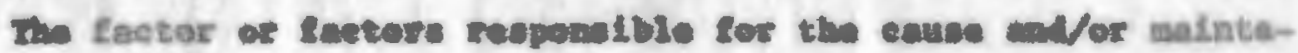
ance of elvoule arterial hypertansion, with the exception of structural

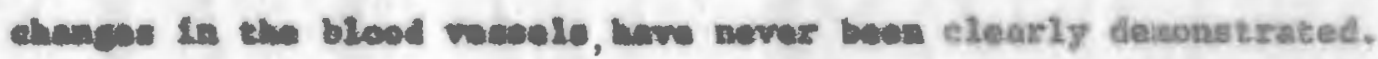

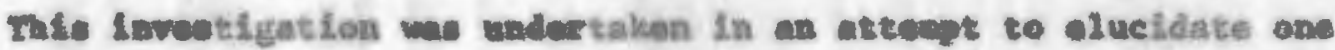
or nowe of these feztore.

The opellle abjectived are:

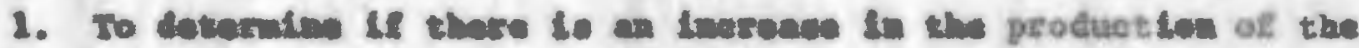

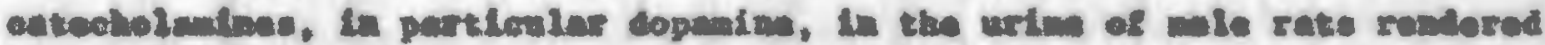

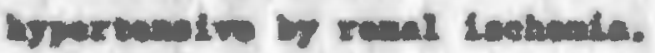

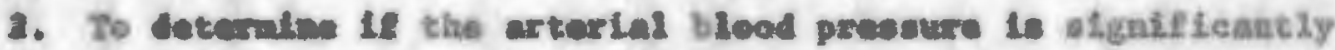
Coprent upa the Inexwes in dopanine produetion.

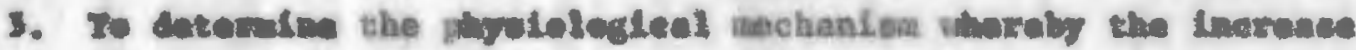

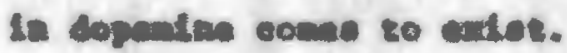

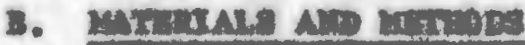

\section{Produetion of Experimental Eypertenston}

Male atbles rete of the spresue Dawley serain weighing 90-100 g wro unad for the investigation. Experinental hypertension wh affected

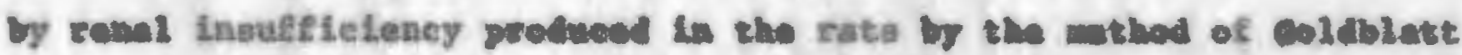

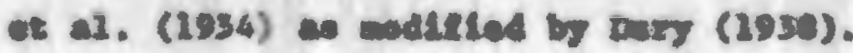

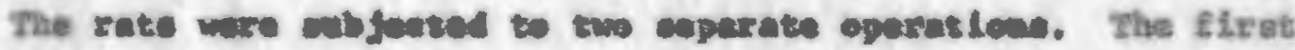

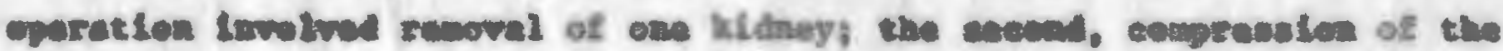

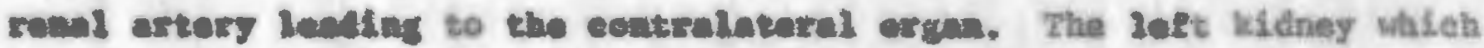

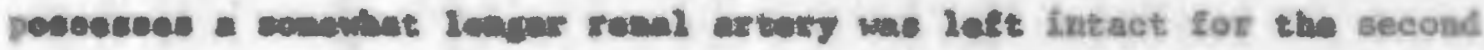
cporatica. Ithar wa the abothotle in all operations. 
Renoval of the right kidosy uss meconplisted by wakisg e dorno-

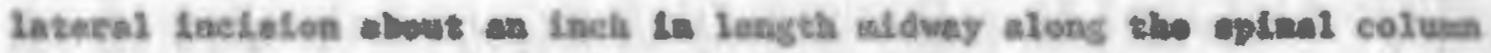

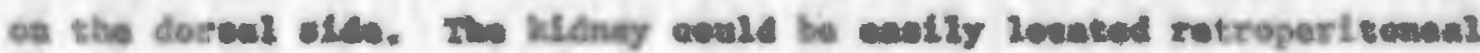

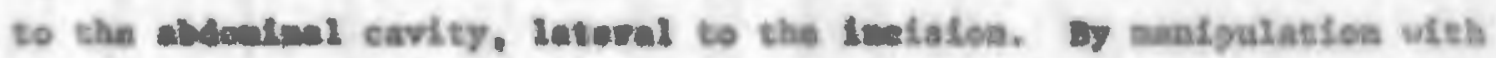

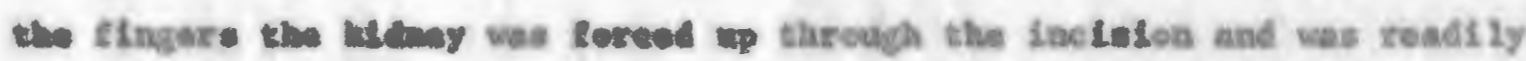

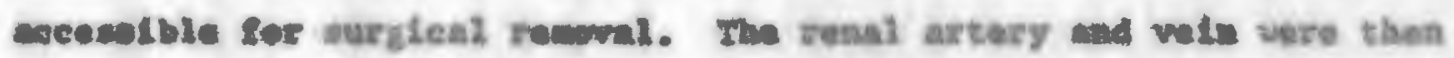

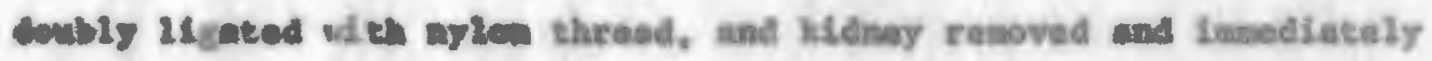

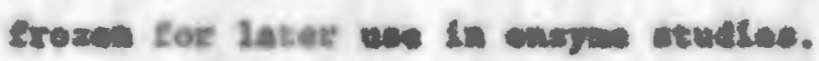

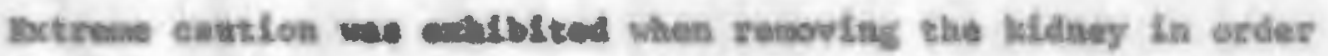

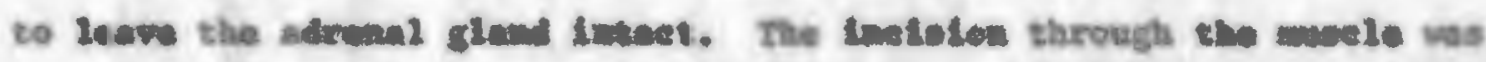

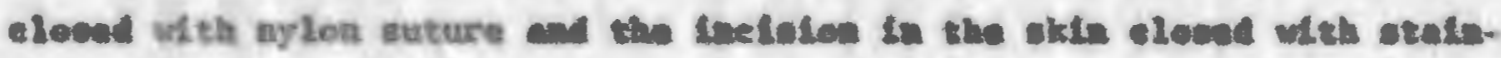
Lees ceed wound elaugs,

Two weelse abbequent to the tifet operation the renal artery to

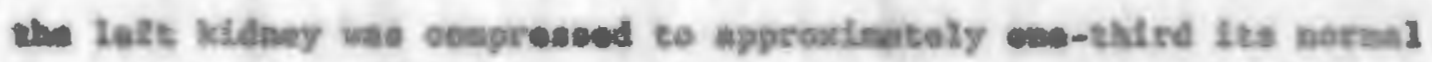
Alamoter at leseribed below.

Th latt renal ertery wa loested by sesho of a one to onh ahd

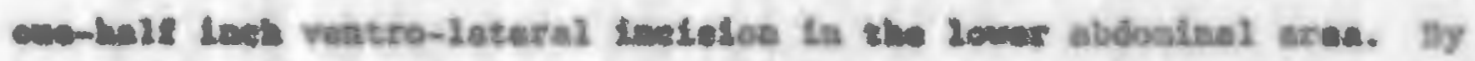

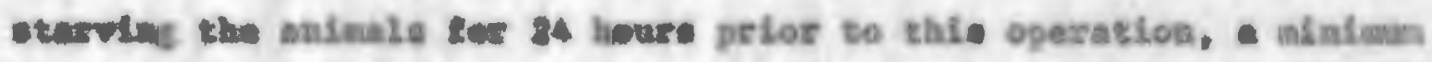

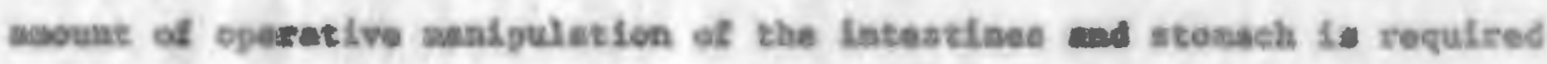

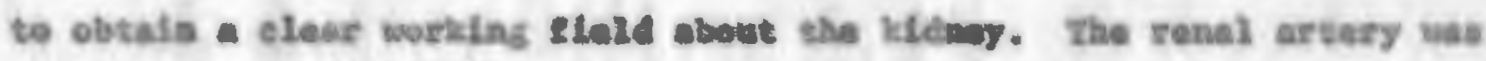
than ceretuliy aeparated from the ronel veln and wo curlu spproxinate-

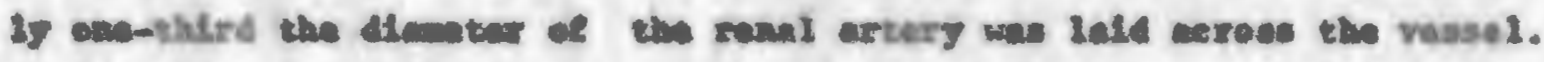
A bylion stives was then placed acotund the vire and the artery and thed

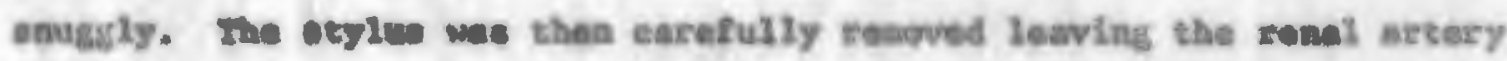

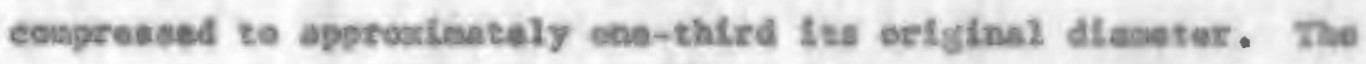

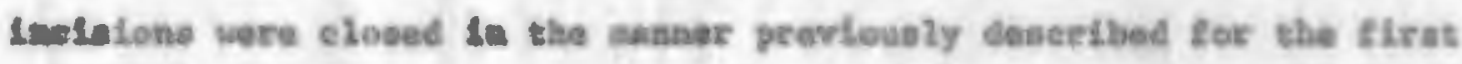
operakien. 


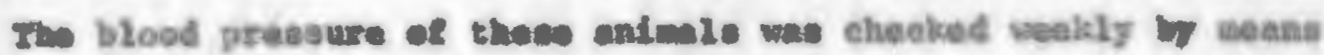
of the photoelectris toneamater. 1

\section{Collectim of vito}

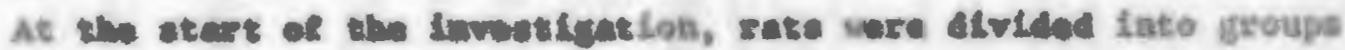

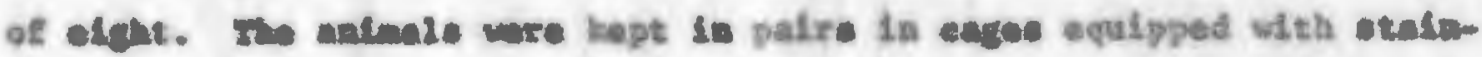

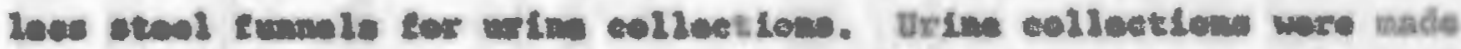

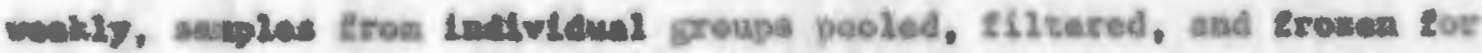

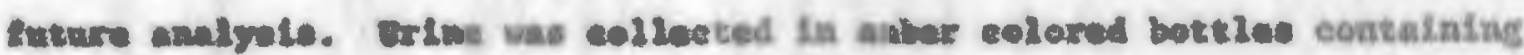
1.0 al ot 2.0 in anturit ald.

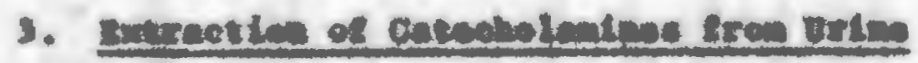

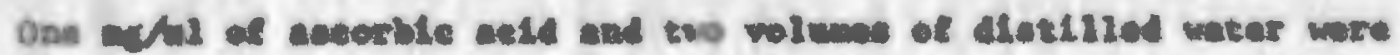

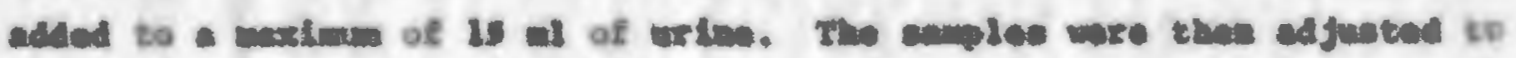
pll 6.5 wth $2.0 \mathrm{~N}$ codtu bylroxide (Crautord and Lav, 395e), the

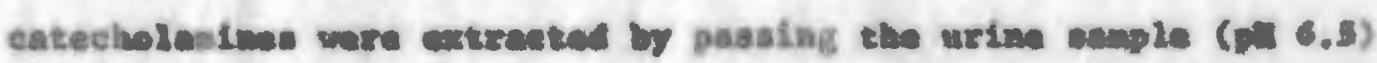

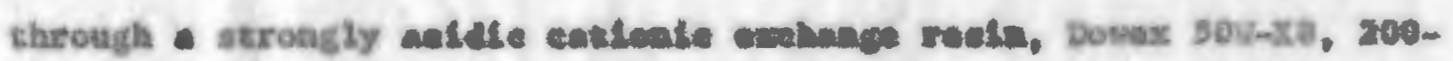

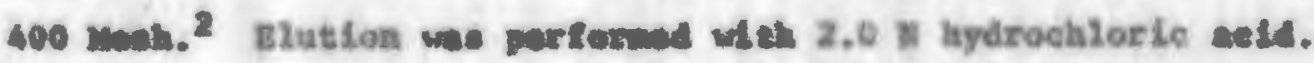

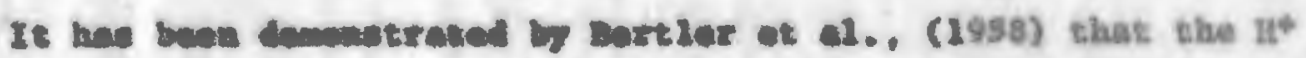

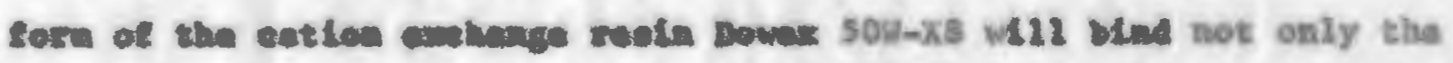

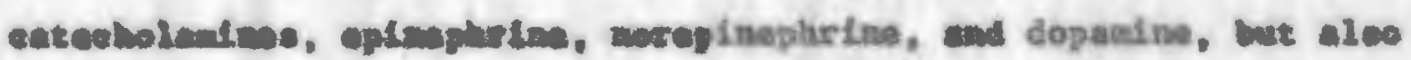

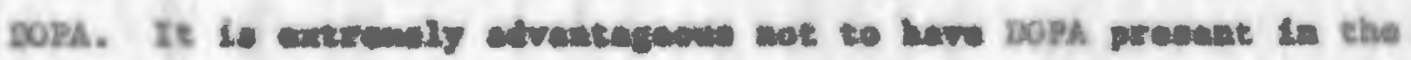

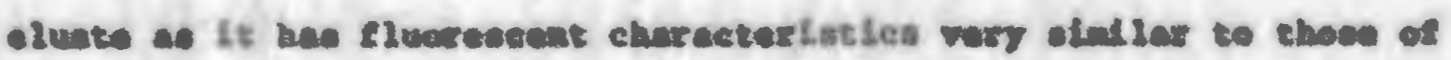

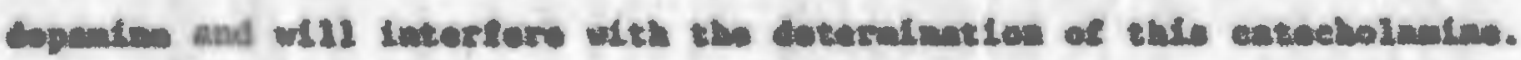

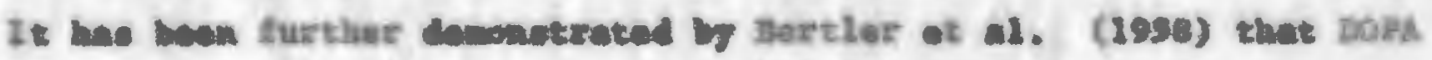

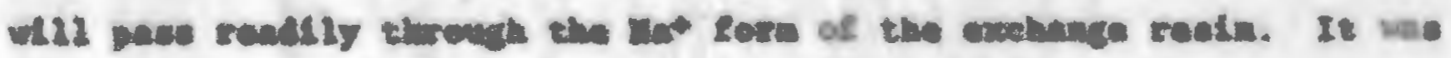

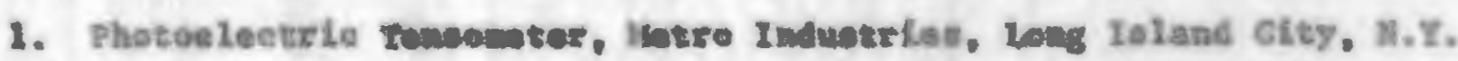

2. Dowex 5on-k8, 200-400 wab is - peoducz of the Dow Ghemieal Co. and

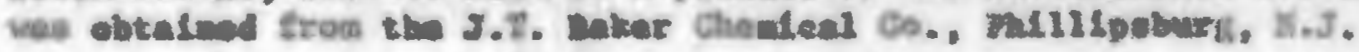


than netsasery to convert the reafn to the Nat forn before use, al the

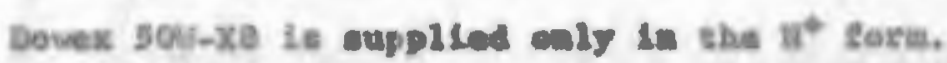

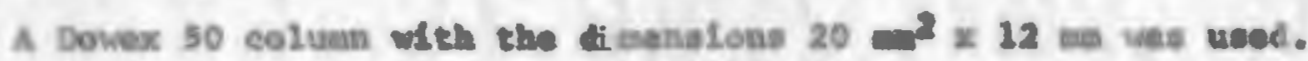

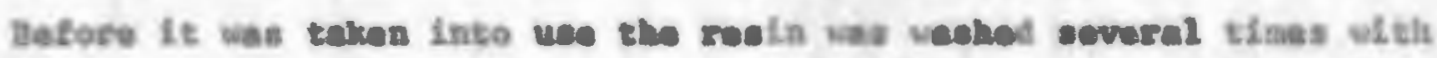
5.0 If sodium hydroxide cellowd with diatilled veer unt Il the afiluent

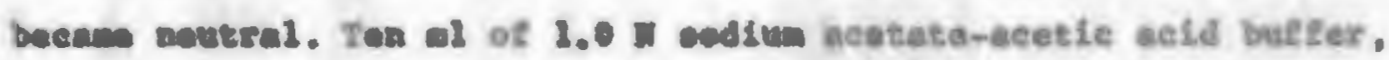
pll 6.0 , when passed through the celuan folloved by $5.0 \mathrm{ml}$ of diat112ed watar. The colum was now raafy for ase.

A 20 al allquot of the extract vas pessed through the columin

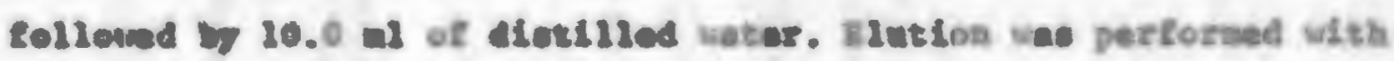

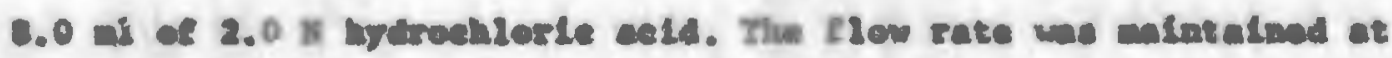
aprecteatedy 0,29 alhinee.

\section{Doterningtea of Bogente}

The deterwatetion of dopanine van earried out accordin to the nethod of Curleoca and valeeck (1958). - medizieation of the nethod of Bertler ot d. (29se).

The plif of the elunte we adjuted te approalnately 6.5 with 5.0

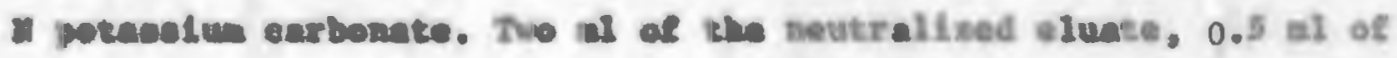

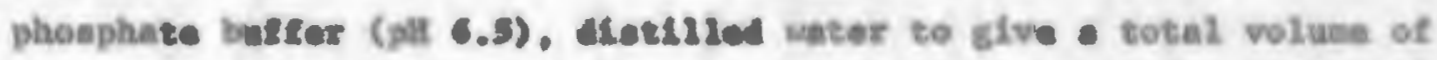

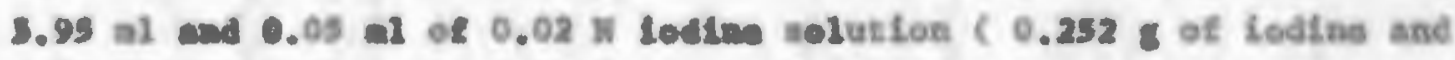

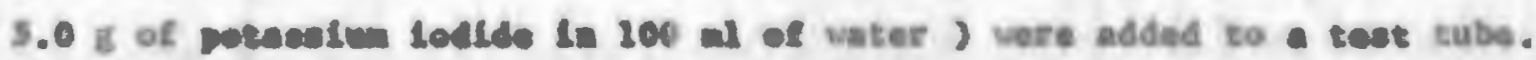

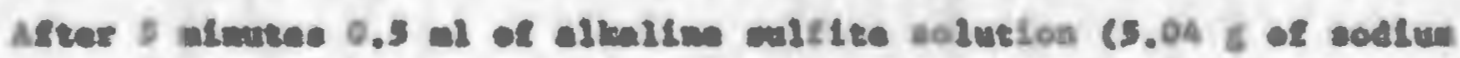

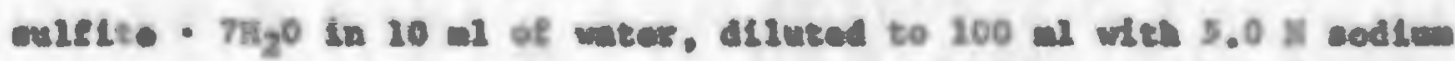

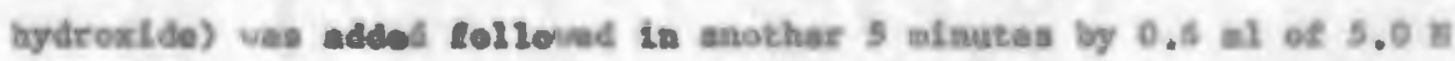
coete set.e.

The eamplen wre then 1 rrediated for 10 minutes under a short: 
vere ultes-violet 11 ght. 3

The 21uprebcence of the saiples was rond on an Anfnco-Bosman Spectrophotolluoroneter. ${ }^{4}$ The setivation and thorebcent wevelengthe wre $325 \mathrm{q} \mu$ and $380 \mathrm{a} \mu$ reopectively, and vere deterained usisg a atandare solution of Copanim at a concentrarion of $0.5 \mu \mathrm{s} / \mathrm{m} 1$. The actvation and fluoresent peaks are ahosn in Eigure 5.

A etendar eurve for know toparine coneentrationa uns run with calh sat of sseples. The equatione for the linas vere determined ascerding vo outle (1956).

$$
\begin{gathered}
\sum x=-b \sum x \\
\sum x y=-\sum x+b x^{2} \\
\hat{y}=-\infty b x
\end{gathered}
$$

A Iinear relationibip such al reported hy Carlsaos (1958) was

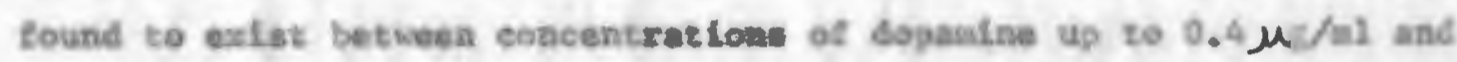
the Elvoraecent Intenalty (IIgare 6 ).

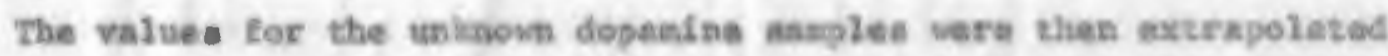
from the celculated ism, $\hat{\mathbf{Z}}=a+b x$. Valwe tor dopenine are reported $\ln \mu n$.

Intermal stendar de were run at variou interval throughedt the

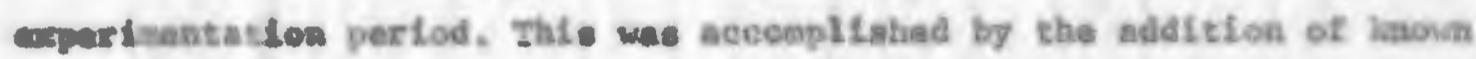
alsounte of dopanifie to the wrine bofore it was processed.

The recevery value tor internal dopand se sandards are reportad In eable 1. It we found that the overage recovery rate of dopanine wen $74.52 \div 10.99$ percent. The percent recovery appesro aceowhet

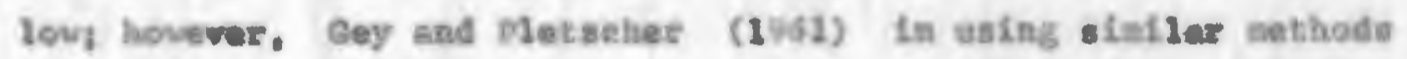

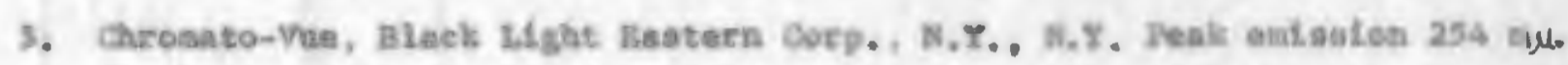

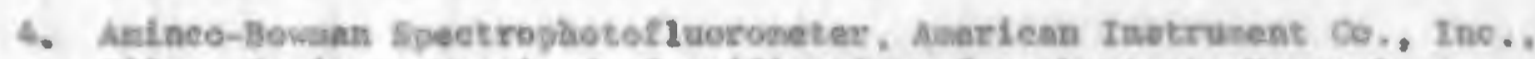
allver Springe, Margland. Apecleications fur the tent: Xenon Lop. sils Arrangewent nueber 5 , Photomultiplier Tabe i> 25. Rased quartz collo vere uaed. 


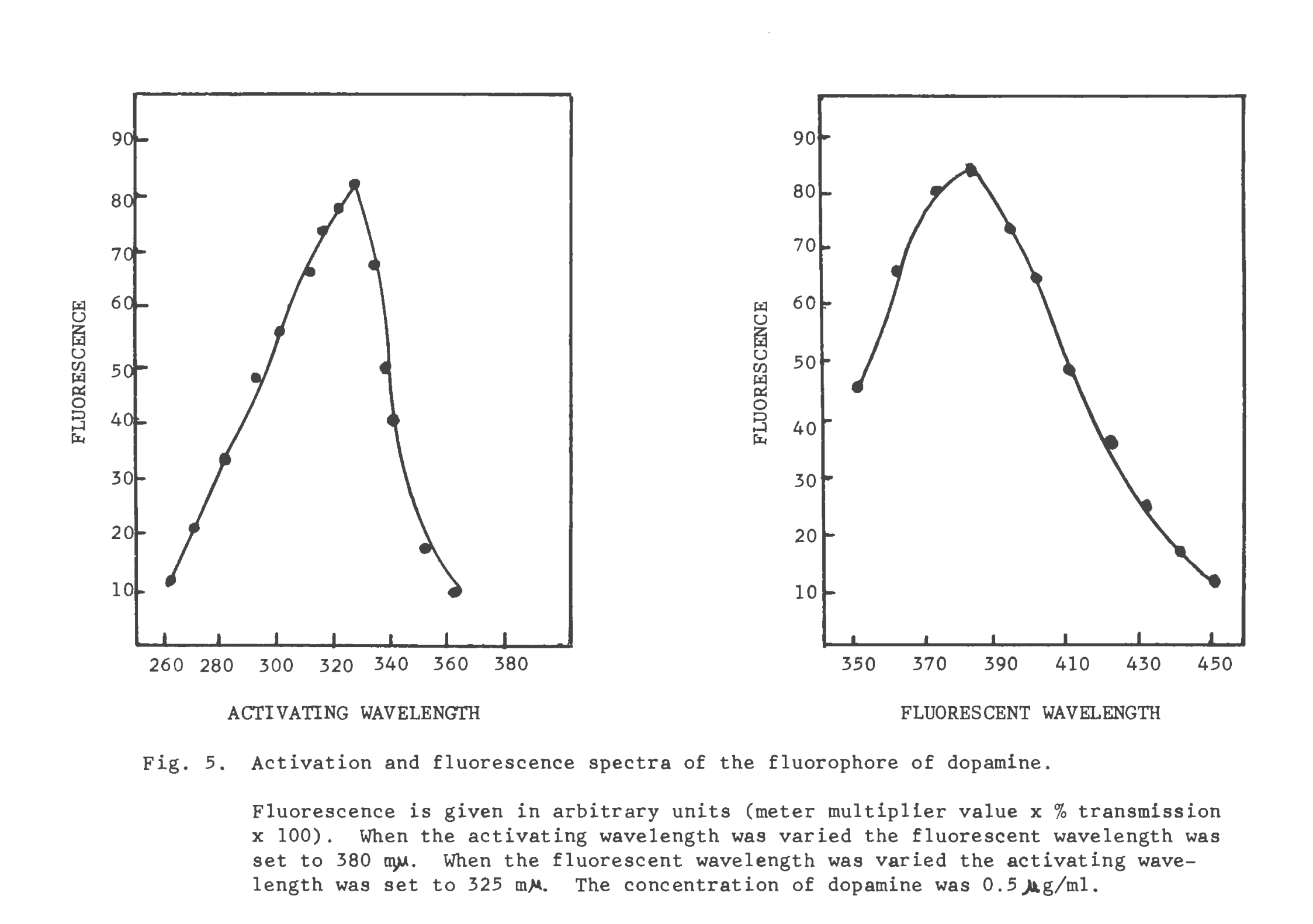


30.

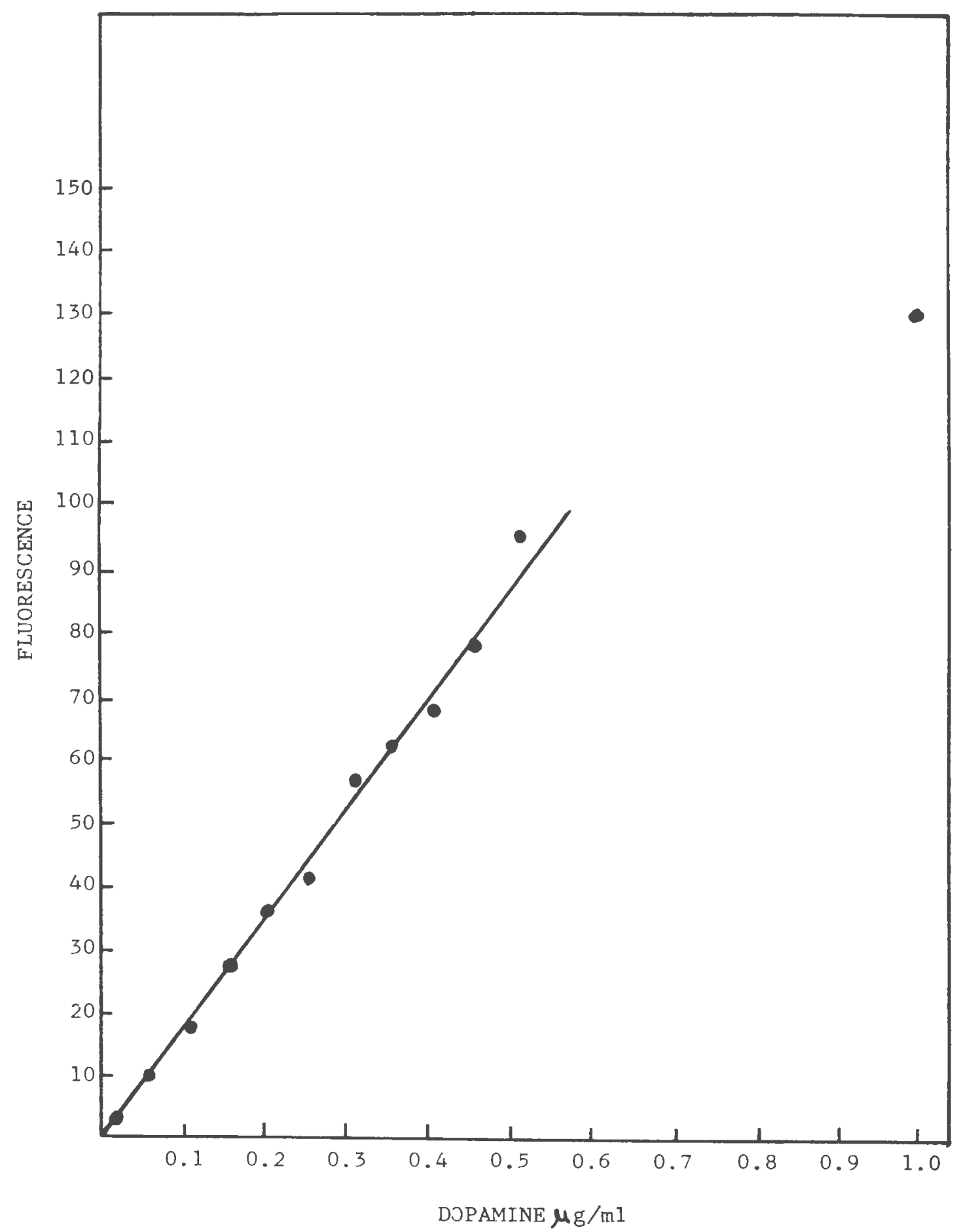

Fig. 6. Fluorescence intensity at varying concentrations of dopamine.

Fluorescence is given in arbitrary units (meter multiplier value $x \%$ transmission $x$ 100). Activating wavelength $325 \mathrm{m \mu}$; fluorescent wavelength $380 \mathrm{m \mu}$ 
31.

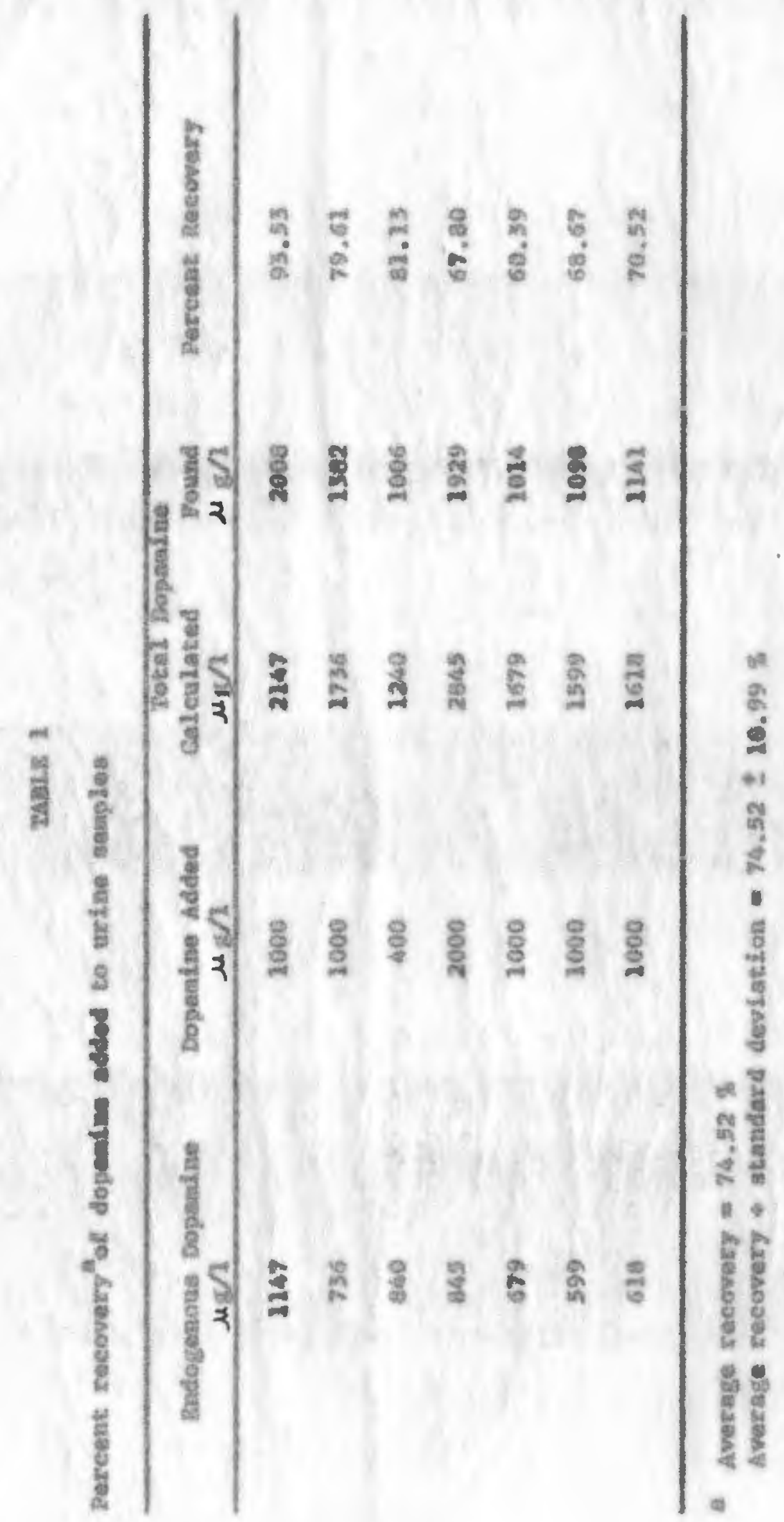


roported recovery of dopuntwe exed to braln hobogenates a low as 10 gerceat.

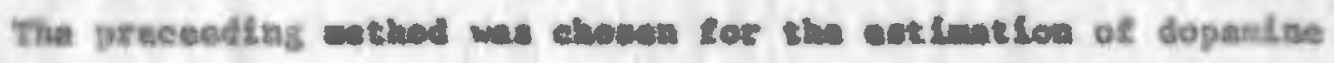

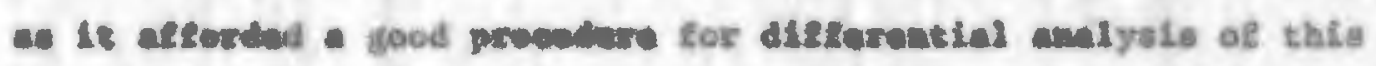

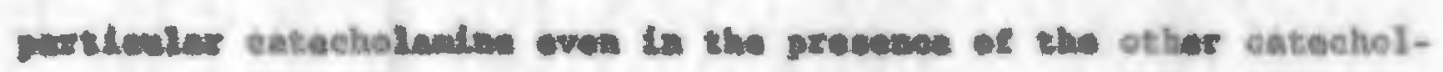
entmes.

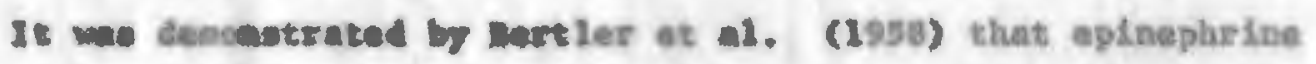
and aurophephere are quantitatively eluted by 1.0 a bydrochlorle

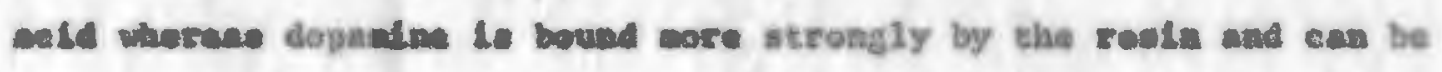
oluted for the not pare ln $\mathbf{8 . 0}$ s hydroohlorle celd.

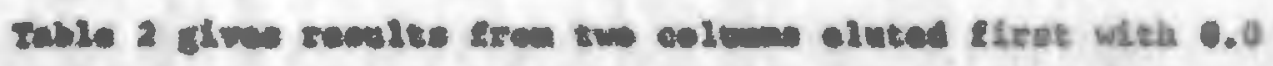

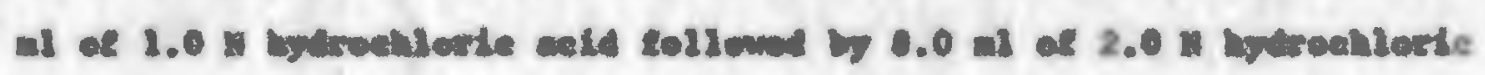
ate.

\section{TAL 2}

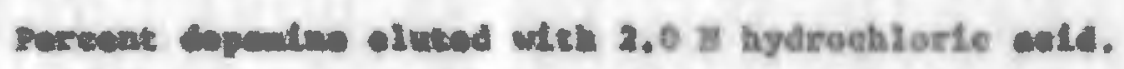

\begin{tabular}{|c|c|c|c|}
\hline Nuaber & $1.0 \mathrm{~N} \frac{\mathrm{BO}}{\mathrm{B}}$ & 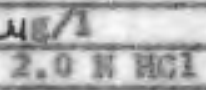 & $\begin{array}{l}\text { Pereent Dopanifne in } \\
\text { second Fraction }\end{array}$ \\
\hline 1 & 313 & 1069 & 77.35 \\
\hline 2 & 392 & 740 & 65.43 \\
\hline
\end{tabular}

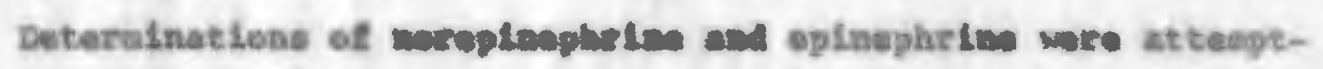

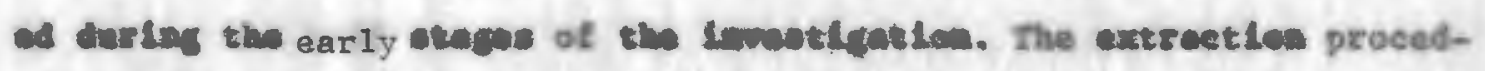

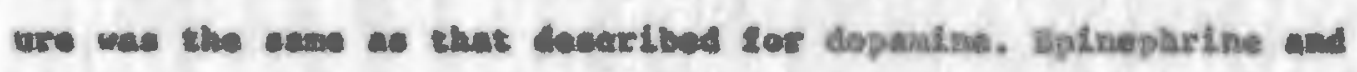

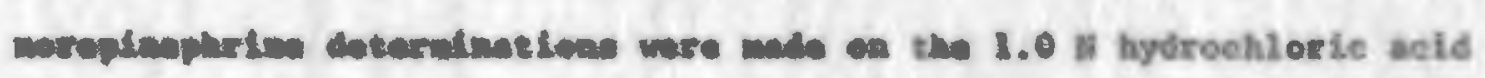

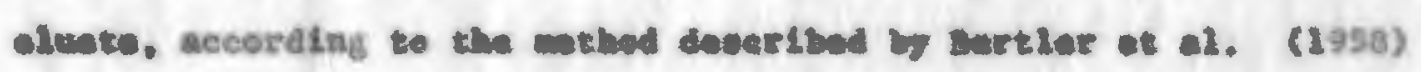

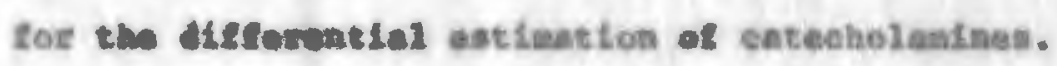

The precanee of eptnephribe and norephnephrine oould not be cetsated. It is bllow that the esounta prosent wre below the 


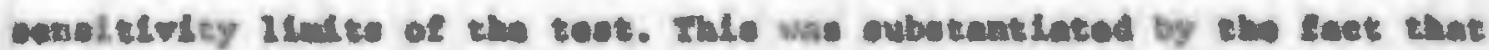

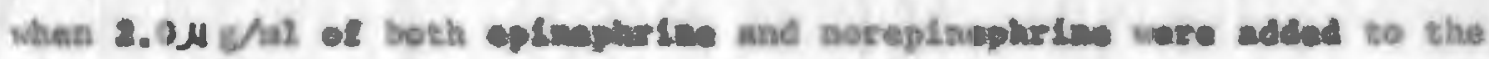
ulew bacow proceabing, recowaries of 12 pereene and 75 pereent raspectLwals ware obteined.

\section{Pugat Chronitortanz}

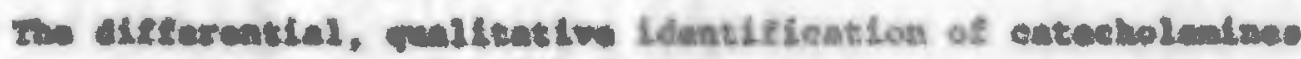
fromurlos by peger ehresategraply was ateeapted.

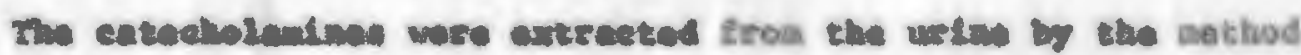
a vav fular and Dalina (19B3).

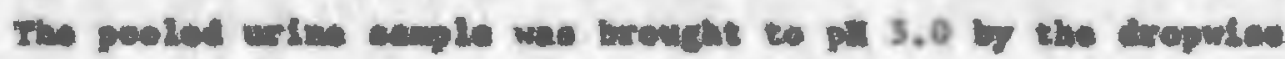

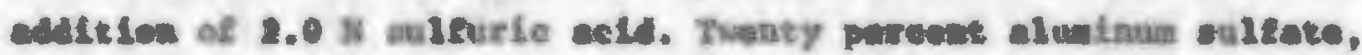

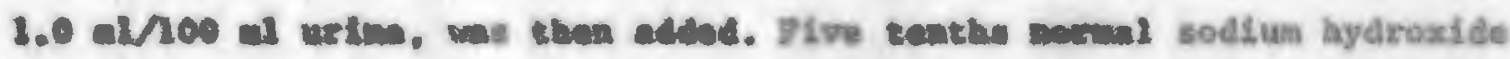

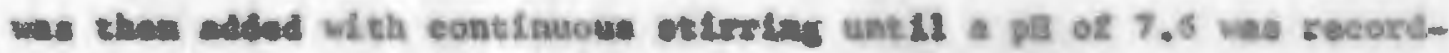

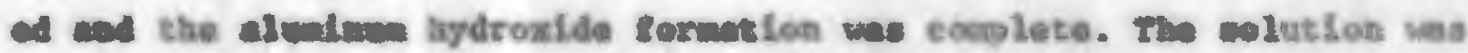

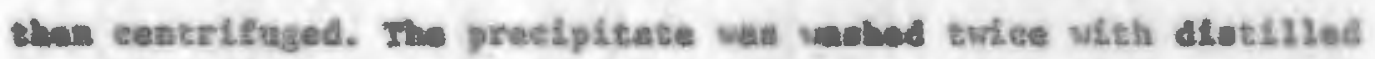

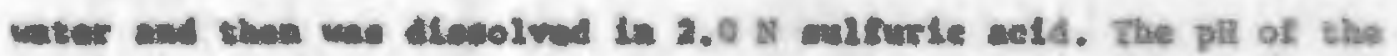

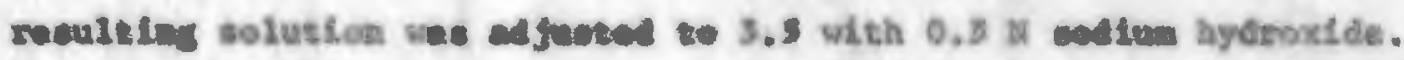
Four volume of equel parte of cthand and acetone vere then added in orrar to preefgitete the calte. The solution sas thon pleoed in the refrigeretor ter curel houro.

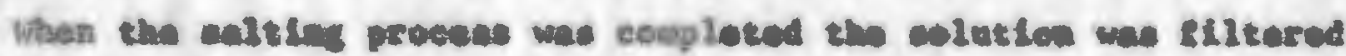

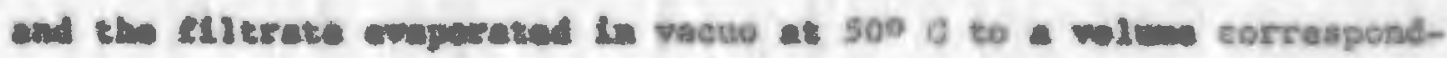

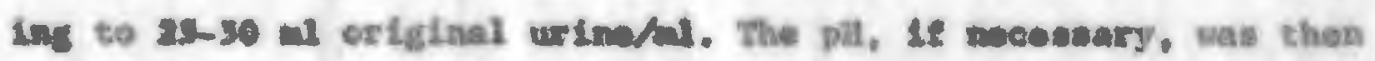
a groted to 3.5. The crteat was then ready for use and we stored is the refrtorroter. 
The extrectlon and coparation of the catecholealmes was at teapt-

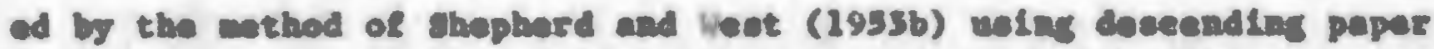
ehromatcyraphy. Saples of the oxtrect aloag with control solutloas of

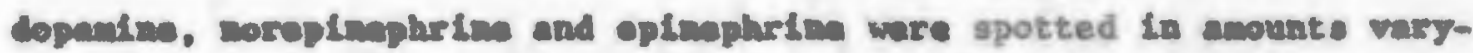
In from 0.03 us to 1.0 us on whatwan $/ 1$ papar. The otripa were elloved to equilibrate epproximately 24 houre in the external phase of an ecotic

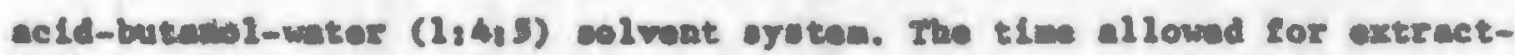
Lon agalant both extornal and Intornal phases varled from 12-20 hours. The ehremategreas were removed erom the teak, allowed to dry ceaplotely and developed whth e potaselum Rorrloyande colution $(0.40 \%)$ 18 $0.5 \mathrm{X}$ phoophate buffor (p) 7.4) ( Sthore and 01in, 1938 ).

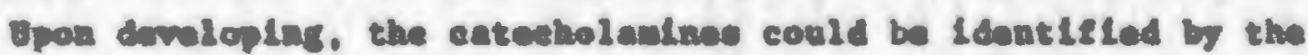
appearence of a plin colored epot. Thle crentuelly faded but geve way to a Ealrif Intoase fluoreansee when vlousd under short wave ultravlolet light. Complete sepairation was cally obtalned with the control opotsi holwver, complete, dletinet separation of the three eatecholenines could not be obtalmad eren tho urimo extracte. A large area, pinkloh in color and pecencelag eluoreseant properties, would appear with an Re vales eorreopeadig to the range of a 2 valwe obenined from control opots of dopanlm, ecrepinophim and epineplurine. It lo posalble hore that Interfortur substanes in the uriso extract hisdored complete exparation of the expounde.

\section{Mloloricel Amer}

In prollatens etudies blonesey techniques wore employed for

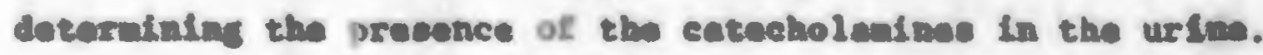

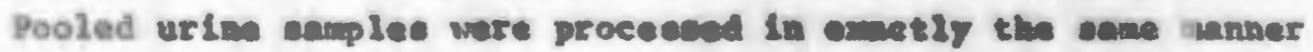
a. deseribed in the precoling section on elremotography. Varying 


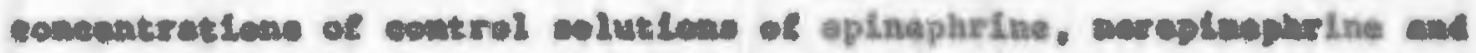

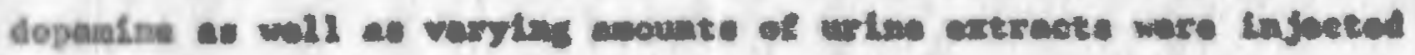

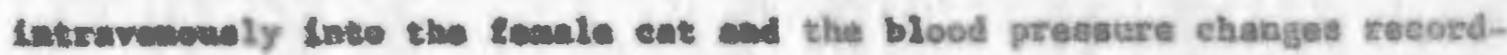

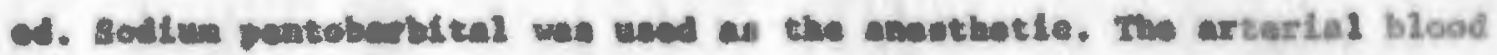

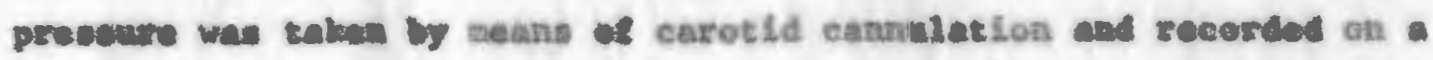

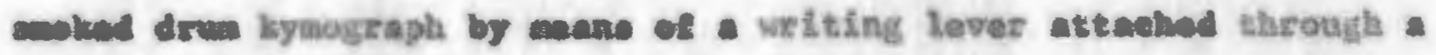
eutury manomer.

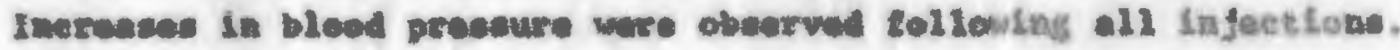

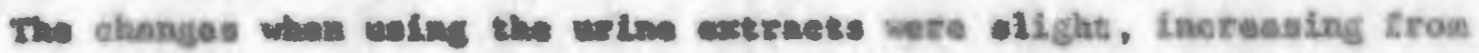
3-10 gersent, and termalent.

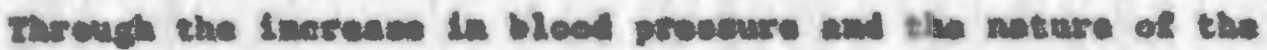

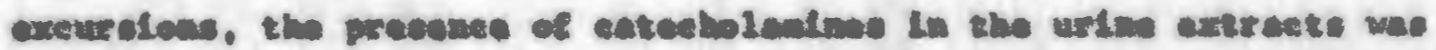

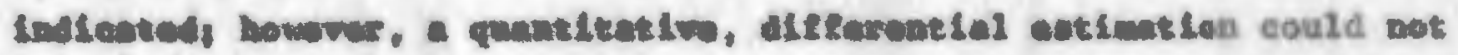
we wate.

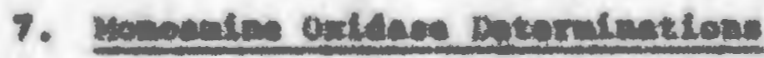

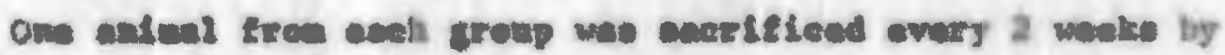

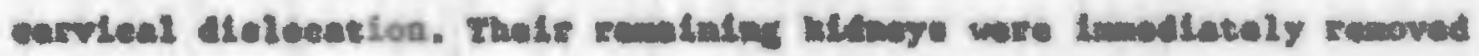
and crean.

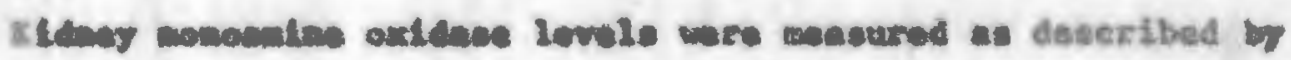

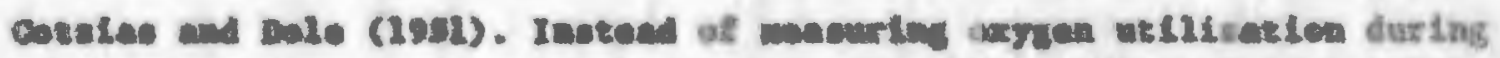

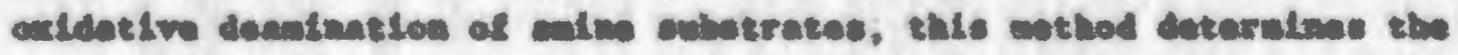

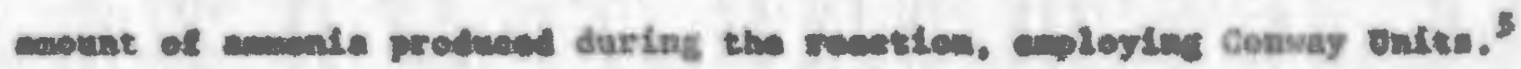

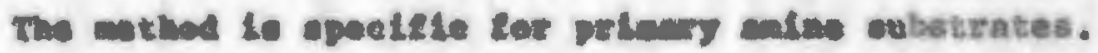

5. Conway valte cemplete with cowr olipe were obtulnod frem the

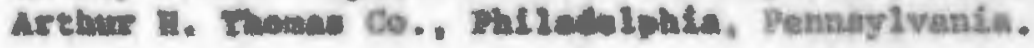


A Algation the of 1 hour was ellemed tor the canye substrate

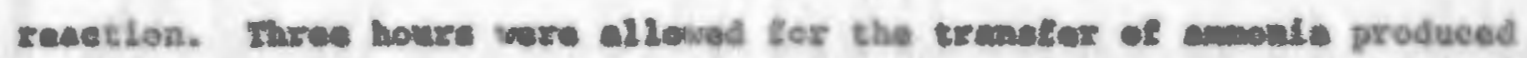
of ew reaction finto the earter wall of the conway onlt.

At tha an of the 3 hours, tleration of the amonla trapped in a

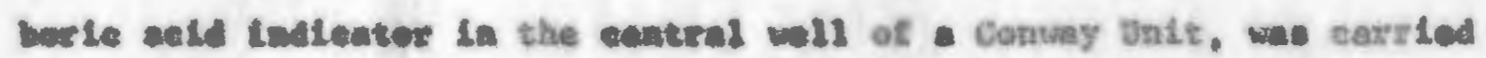

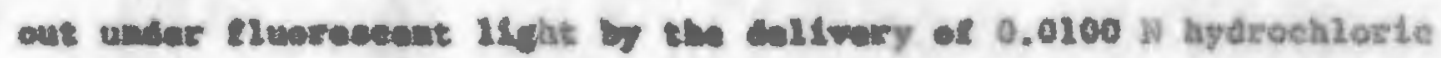

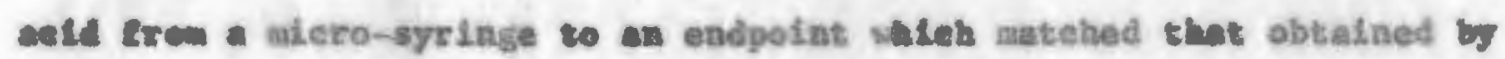
placing $1.0 \mathrm{ml}$ of the burle celd Indeator solution in the contrel imll of a dopleate Commey unt.

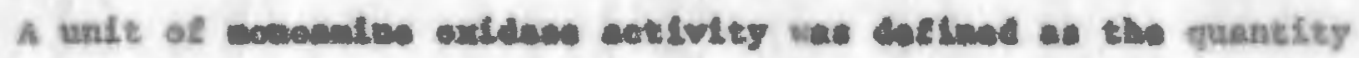

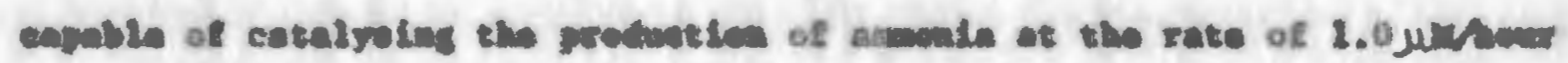

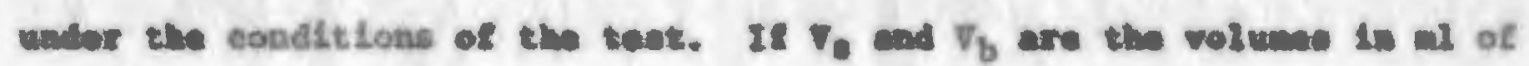

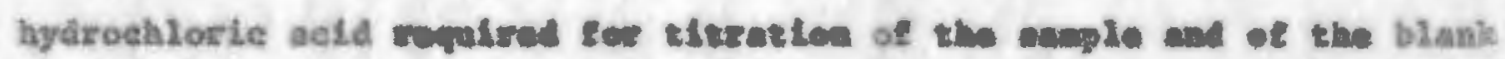

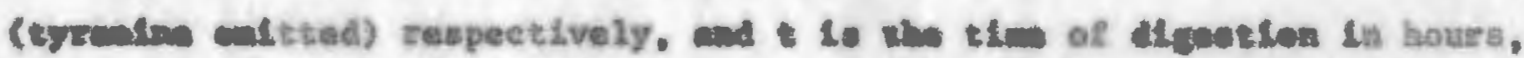
the number of units of ongye contated in the ample is is given by 0 a

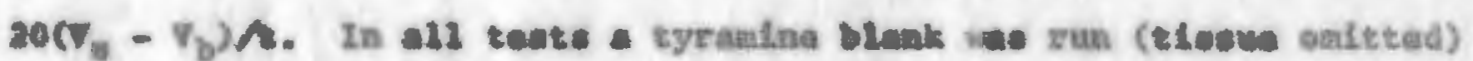
and the vole was oultracted trou $v_{\mathrm{g}}$. 


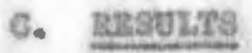

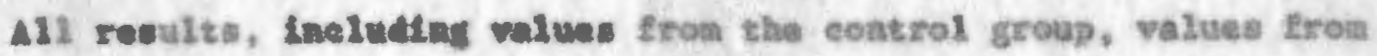
Eha Individual tast groups, poeled date fron the test groups and otatstLoul analysea ore presented under this section.

1. Data for the Control Group are preaented in raBLs 3. 


\section{TABLR 3}

Control Group. Belationahip of urinary dopanine levele (peolod saraples) to arterthl blood pressure (group mean) and lidiney monosmins oxidase cativity in male rats."

\begin{tabular}{|c|c|c|c|c|}
\hline $\begin{array}{l}\text { Weels } \\
\text { pollowing } \\
\text { ist Oper. }\end{array}$ & $\begin{array}{c}\text { Dopemine } \\
\mu g / 2\end{array}$ & $\begin{array}{l}\text { Dlood } \\
\text { meovere } \\
\text { and Ils } \\
\end{array}$ & $\begin{array}{l}\text { Honoanine } \\
\text { Oxldase } \\
\text { cetvity } \\
6 \times 10^{4}\end{array}$ & 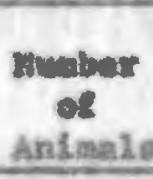 \\
\hline Contzol & 980 & 125.60 & 23 & 8 \\
\hline \multicolumn{5}{|c|}{ girse operation } \\
\hline$T$ & & 150,00 & & 5 \\
\hline 2 & 845 & 120.85 & & 6 \\
\hline 5 & $\$ 99$ & 122.50 & & 6 \\
\hline 4 & 679 & 122.30 & 31 & 6 \\
\hline 5 & 647 & 133.75 & 38 & $\$$ \\
\hline 6 & 480 & 110.75 & & 4 \\
\hline 8 & 441 & 94.00 & 14 & 4 \\
\hline
\end{tabular}

a right nephrectony 
35.

2. Data for the Individual Teat Groupe 1-6 are presented In TABLES 4-9. 


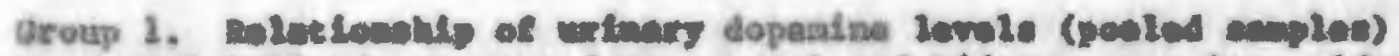

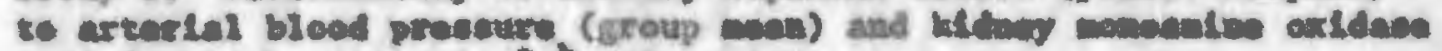

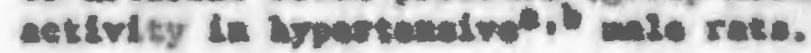

\begin{tabular}{|c|c|c|c|c|}
\hline $\begin{array}{l}\text { Week } \\
\text { 9o12ow1ng } \\
2210005 .\end{array}$ & $\begin{array}{c}\text { Depentine } \\
\mu \mathrm{A}\end{array}$ & 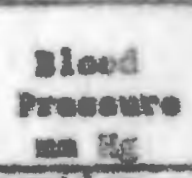 & $\begin{array}{l}\text { Monoantine } \\
\text { Oxidase } \\
\text { Aot } 1 \text { vity } \\
y \times 10^{4} \\
\end{array}$ & 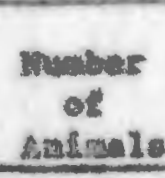 \\
\hline \multicolumn{5}{|c|}{ Rrot Godrton } \\
\hline Controle & & 127.30 & 31 & a \\
\hline antrel & 323 & & & B \\
\hline Coutrol & 711 & 232.50 & & 0 \\
\hline \multicolumn{5}{|c|}{ 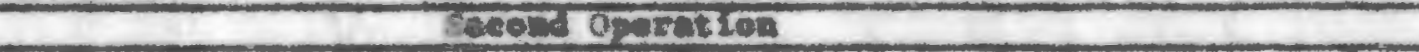 } \\
\hline$T$ & $350^{\circ}$ & $14, .00$ & & 3 \\
\hline 2 & 390 & 148.00 & & 5 \\
\hline 3 & & 161,00 & & 5 \\
\hline$\bullet$ & $3 m$ & 104.00 & $\mathbf{2 1}$ & B \\
\hline$s$ & 2010 & 105.00 & & 4 \\
\hline 6 & as & 200.00 & & 4 \\
\hline 7 & 839 & 199.00 & & 4 \\
\hline a & 120 & 100.60 & & $s$ \\
\hline 9 & 2317 & 14.67 & & 3 \\
\hline 10 & 932 & 102.67 & & 3 \\
\hline 11 & 214 & & & 2 \\
\hline 12 & 183 & 270.00 & . & 2 \\
\hline is & 221 & 175.00 & & 2 \\
\hline 10 & 97 & 170.00 & 10 & 2 \\
\hline 22 & 295 & 100.00 & 34 & 1 \\
\hline
\end{tabular}

- Bight mephreetony

- Lefe coenl arterlal ceepsenton

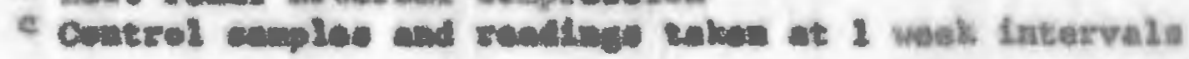


rasus 3

Group 2. Relstionship of uriaary dopanine levels (pooled nasples) to erterial blood pressure (group mean) ead hideey monoasho oxidase activity in hypertensives, b ale sate.

\begin{tabular}{|c|c|c|c|c|}
\hline $\begin{array}{l}\text { Wealk } \\
\text { Fellowing } \\
\text { 2nd oger. }\end{array}$ & $\begin{array}{l}\text { Dopeaine } \\
\mu \mathrm{y} / 2\end{array}$ & $\begin{array}{l}\text { Bleod } \\
\text { Pressure } \\
\text { ro lig }\end{array}$ & $\begin{array}{l}\text { Konoatnine } \\
\text { Ozidase } \\
\text { Aetivity } \\
\text { D } x 10^{6}\end{array}$ & $\begin{array}{c}\text { Number } \\
\text { of } \\
\text { Anisale }\end{array}$ \\
\hline Colacrole- & 479 & 124.29 & & 7 \\
\hline \multicolumn{5}{|c|}{ Firse operatiol } \\
\hline Control & & 126.29 & 23 & 7 \\
\hline \multicolumn{5}{|c|}{ Seeond Operar Log } \\
\hline I & 55ह & & & 2 \\
\hline 2 & & 150,00 & & 2 \\
\hline $\mathbf{3}$ & 673 & & & 2 \\
\hline 4 & & 155.00 & & 2 \\
\hline 3 & 541 & 265.00 & & 2 \\
\hline 6 & 579 & $\mathbf{2 3 2 . 3 0}$ & & 2 \\
\hline 7 & 371 & & & 2 \\
\hline 8 & 769 & $\mathbf{2 7 0 . 0 0}$ & & 2 \\
\hline 9 & & 163.00 & & 2 \\
\hline 21 & 653 & 255.00 & 23 & 2 \\
\hline 19 & 570 & 170.00 & 25 & 2 \\
\hline
\end{tabular}

A Righe nepheeeteny'

Laft renal arterial coinpreseles

e Control anaplea and rodisg taben at 1 veak Latorvalo 


\section{TASLม 6}

Group 3. Relat lonship of urfuery dopanine levals (poolod sanplea)

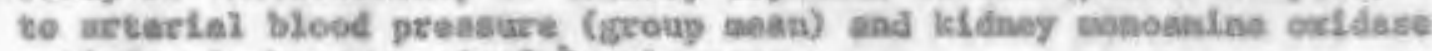
activity is hypertenslvea, b inla rate.

\begin{tabular}{|c|c|c|c|c|}
\hline $\begin{array}{l}\text { Weele } \\
\text { Foliowing } \\
\text { 2nd Oper. }\end{array}$ & $\begin{array}{c}\text { Dopasinas } \\
\mu s / 2\end{array}$ & $\begin{array}{l}\text { Blood } \\
\text { Pressurs } \\
\text { on flis }\end{array}$ & $\begin{array}{l}\text { Tonosenine } \\
\text { Oxidase } \\
\text { Aetivitigy } \\
\text { g x 10\% }\end{array}$ & $\begin{array}{c}\text { Thublas } \\
\text { at } \\
\text { Anteale }\end{array}$ \\
\hline Costror ${ }^{2}$ & 657 & 121.08 & & 6 \\
\hline \multicolumn{5}{|c|}{ Trrat operation } \\
\hline Control & & 118.13 & \$10 & 8 \\
\hline \multicolumn{5}{|c|}{ Second Operation } \\
\hline$T$ & 639 & 185.00 & & $\frac{\pi}{4}$ \\
\hline 2 & 604 & 253.00 & 26 & 4 \\
\hline 5 & 503 & 100.00 & & 3 \\
\hline 4 & 632 & 237.67 & & 3 \\
\hline 5 & 419 & 160.00 & & 3 \\
\hline s & 894 & 191.67 & 28 & 3 \\
\hline e & 389 & 205,00 & & 2 \\
\hline 9 & 494 & 197.50 & & 2 \\
\hline 10 & 629 & 193.00 & & 2 \\
\hline 21 & $1 x 7$ & 130.00 & & 2 \\
\hline 12 & 2589 & 102.50 & 28 & $z$ \\
\hline 23 & Las & 280.00 & & $\mathbf{I}$ \\
\hline 14 & 754 & 280.00 & 19 & 1 \\
\hline
\end{tabular}

A sighs nephrateny

- left renal arturial comprasalon

- Contro 1 aamples and readiage tam at 1 veel fatervale 
Group 4. Ilelationsaip of untwry dopanine lowis (pooled sauploo) te artolal blend pressure ( ectsitty In laypertensivea,b cale rats.

\begin{tabular}{|c|c|c|c|c|}
\hline $\begin{array}{l}\text { beli } \\
\text { and oper. } \\
\text { 2nd }\end{array}$ & $\begin{array}{c}\text { Dopantine } \\
\mu \in / 2\end{array}$ & $\begin{array}{l}\text { Dlow } \\
\text { Pressure } \\
\text { nea thr }\end{array}$ & $\begin{array}{l}\text { Wotioanine } \\
\text { Oxidase } \\
\text { aetivity } \\
y \times 10^{4}\end{array}$ & $\begin{array}{c}\text { Humber } \\
\text { of } \\
\text { Antrads }\end{array}$ \\
\hline Conter $1^{-}$ & 1358 & & & \\
\hline Control & & 120.00 & & 8 \\
\hline \multicolumn{5}{|c|}{ Iras operazion } \\
\hline Contrel & 757 & & 38 & 8 \\
\hline Control & 075 & & & 6 \\
\hline Control & 739 & 127.50 & & 6 \\
\hline \multicolumn{5}{|c|}{ Becond gperaclon } \\
\hline$T$ & 430 & 145.00 & & 2 \\
\hline 2 & 502 & 100.00 & & 2 \\
\hline 3 & 400 & 135.00 & & 2 \\
\hline 4 & 80 & 207.50 & & 2 \\
\hline$s$ & 300 & 198.00 & & 2 \\
\hline 7 & as & 107.30 & & 2 \\
\hline 8 & 5 & 170.00 & & 2 \\
\hline 9 & 763 & 200.00 & 30 & 2 \\
\hline 20 & 282 & $\mathbf{2 9 0 . 0 0}$ & & 1 \\
\hline 12 & 1280 & 102.6 & & 1 \\
\hline 12 & 840 & 280.00 & & 1 \\
\hline
\end{tabular}

a I I ght nephrectoany

- Idt remal arterial con made

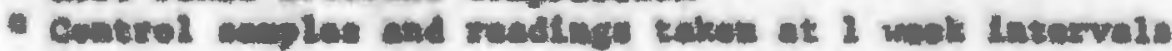




\section{고ㄴㅗㅛ 0}

Greup 3. Relatlonaluip of urinery dopentue levela (gooled aemples)

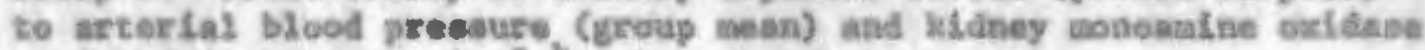
eativity in hypertenadvat, b nale rass.

\begin{tabular}{|c|c|c|c|c|}
\hline $\begin{array}{l}\text { keak } \\
\text { Pollowlag } \\
\text { and Gper. }\end{array}$ & $\begin{array}{l}\text { Dopasaine } \\
\mu \mathrm{g} / \mathrm{A}\end{array}$ & $\begin{array}{l}\text { slood } \\
\text { Preasure } \\
\text { eng } 8 \mathrm{~g}\end{array}$ & $\begin{array}{l}\text { doposissine } \\
\text { oridase } \\
\text { Aetivity } \\
\text { v x } 10^{\circ}\end{array}$ & $\begin{array}{l}\text { Nenber } \\
\text { of } \\
\text { sntrole }\end{array}$ \\
\hline Coktroge & 96 & & & ह \\
\hline Gonerol. & & 122,13 & & 8 \\
\hline \multicolumn{5}{|c|}{ Drst Ogeration } \\
\hline Control & क्र54 & & 30 & 8 \\
\hline Coatreol & 737 & & - & 7 \\
\hline Gontrol & $4 s \mathrm{a}$ & 124.29 & & 7 \\
\hline \multicolumn{5}{|c|}{ second oparasion } \\
\hline $\mathbf{T}$ & कढा & 234.17 & & 8 \\
\hline 2 & 623 & 21:83 & & 6 \\
\hline 3 & 559 & 177.20 & 22 & 6 \\
\hline 4 & 514 & 382.00 & & 5 \\
\hline 5 & 854 & 136.00 & 44 & 5 \\
\hline 6 & 626 & 187.50 & & 4 \\
\hline 7 & 976 & 182.30 & & 4 \\
\hline a & 1063 & 293.75 & 34 & 6 \\
\hline 9 & 565 & 195.00 & & 3 \\
\hline 10 & 754 & 203.33 & 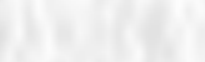 & 3 \\
\hline 18 & 607 & 189.35 & 14 & $\mathbf{3}$ \\
\hline 12 & 1082 & 195.00 & & 2 \\
\hline 13 & 495 & 210.00 & 9 & 2 \\
\hline 19 & 342 & & 25 & 1 \\
\hline
\end{tabular}

- Right nepheactomy

bekt runal arterial compresaton

" Control semples and readings taliah at 1 veek intarvals 
Oroup 6. Belationohip of urinery Gopanine levole (pooled seaples) to arterial bloce prosoum (groep anen) and kidney woboanino oxddabe eetivity in hopertana ive,$b$ ale rate.

\begin{tabular}{|c|c|c|c|c|}
\hline $\begin{array}{l}\text { Ueek } \\
\text { Follourlng } \\
\text { 2nd oper. }\end{array}$ & $\begin{array}{l}\text { topanathe } \\
\mu y / 2\end{array}$ & 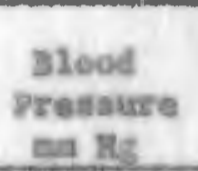 & $\begin{array}{l}\text { Monoesine } \\
\text { gxidase } \\
\text { Aetivity } \\
\text { n z } 10^{\circ}\end{array}$ & $\begin{array}{c}\text { Houser } \\
\text { of } \\
\text { Asinals }\end{array}$ \\
\hline Controgt" & 906 & 116.25 & & \\
\hline \multicolumn{5}{|c|}{ Pros oparatios } \\
\hline Conerol & उड़क्ष & & 34 & 8 \\
\hline Control & 459 & & & 8 \\
\hline Control & 610 & 120.03 & & 6 \\
\hline \multicolumn{5}{|c|}{ second gperaínon } \\
\hline $\mathbf{T}$ & 559 & 131.60 & & s \\
\hline 2 & 681 & 147.30 & 19 & 6 \\
\hline 3 & $\$ 26$ & 265.00 & & 5 \\
\hline 4 & $4 \%$ & 149.00 & & 5 \\
\hline 5 & 360 & 17.00 & 16 & 5 \\
\hline 6 & 2042 & 291.91 & & 4 \\
\hline$y$ & 21 & 108.00 & & 4 \\
\hline 8 & 120 & 281.75 & 25 & 4 \\
\hline 9 & 1013 & 198.33 & & 3 \\
\hline 20 & 963 & 201.67 & 26 & 3 \\
\hline $\mathbf{2 1}$ & 926 & $190 ; 00$ & & 2 \\
\hline 22 & 736 & 180.00 & 18 & 2 \\
\hline 14 & 556 & & 24 & 1 \\
\hline
\end{tabular}


46.

1. Pooled Data troin all Indtvideal Teat Groups are preasated in TABLS 10 and $\mathbf{2 1}$ and DTGura 7. 


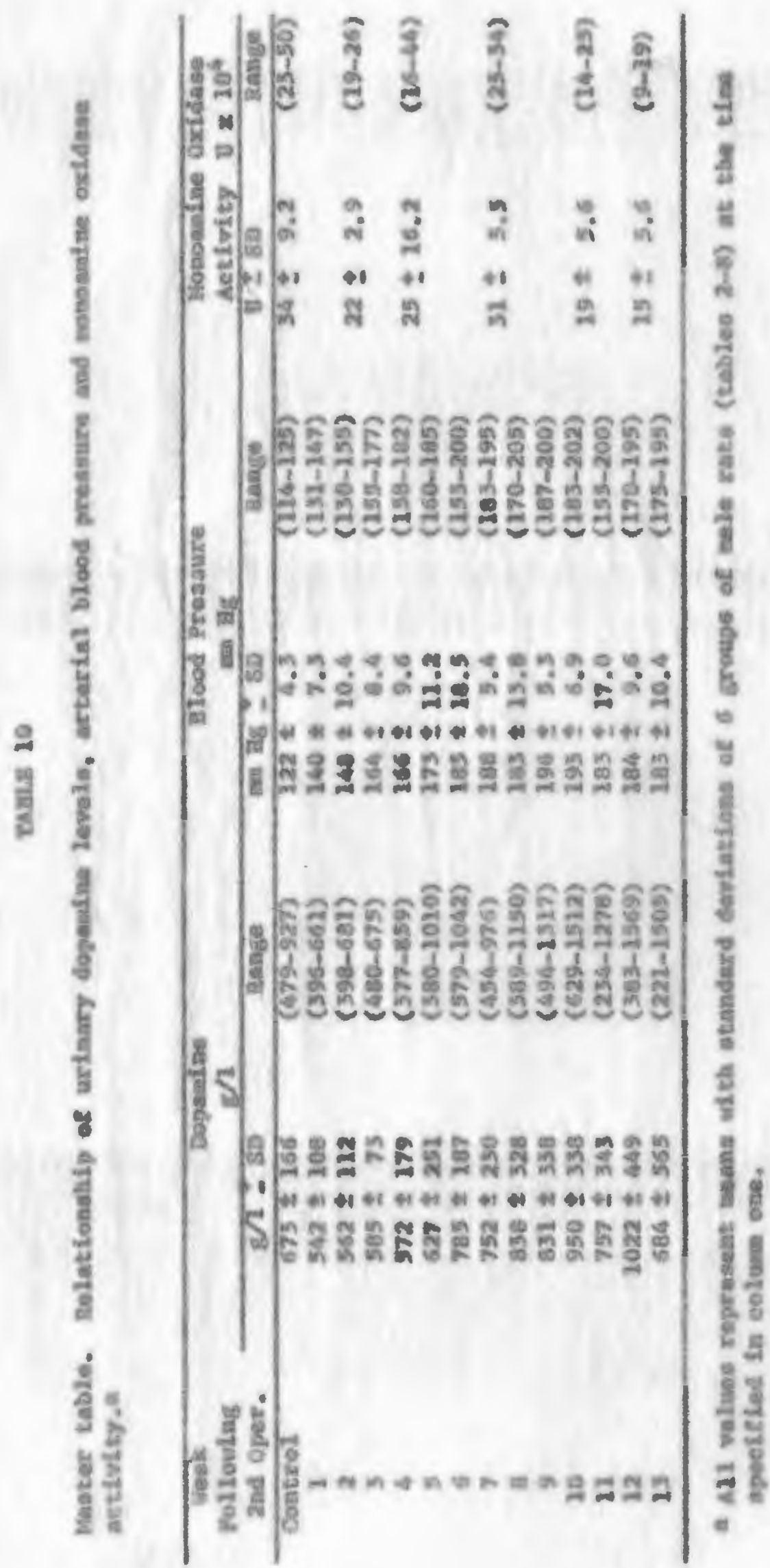




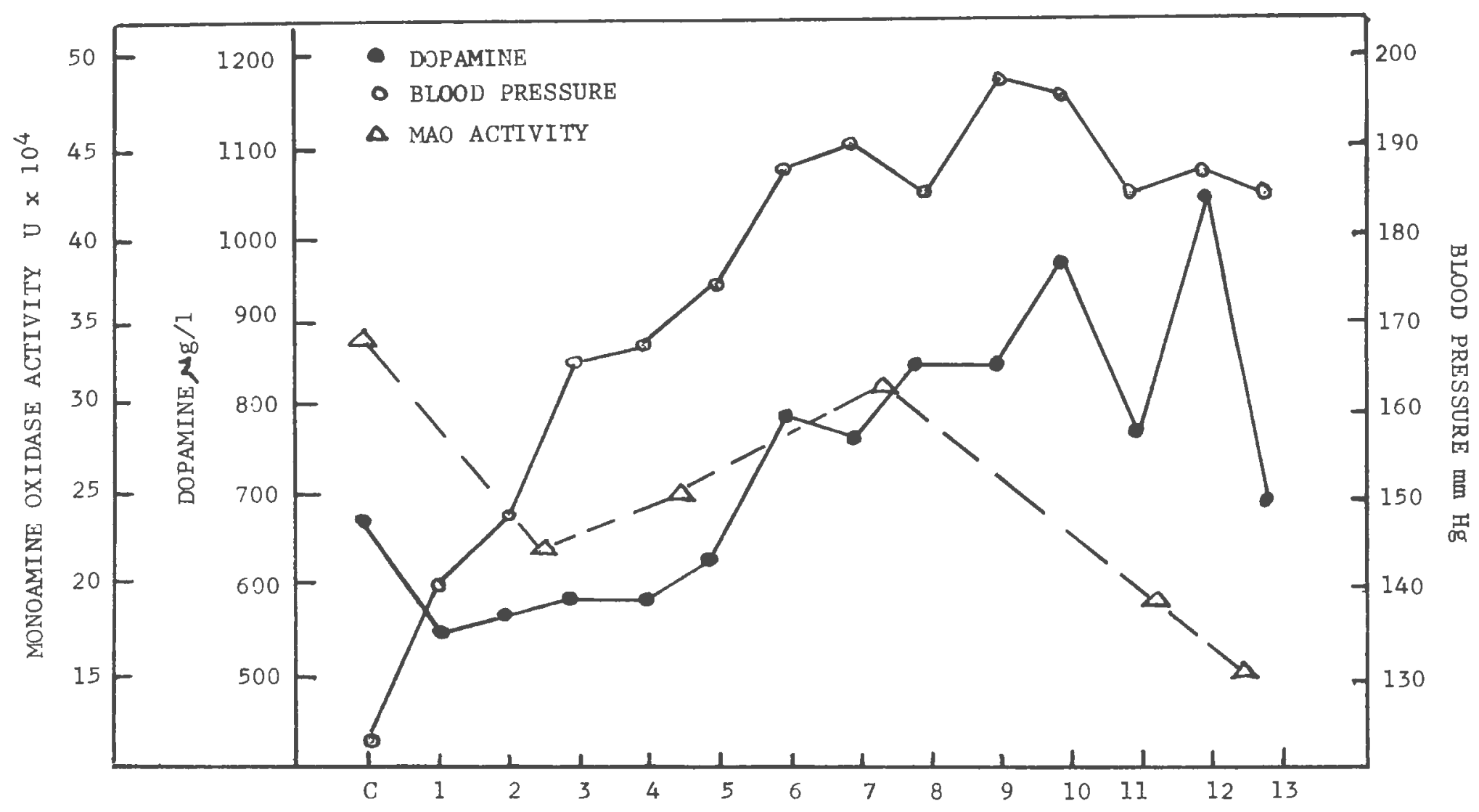

WEEKS AFTER SECOND OPERATION

Fig. 7. Master graph. Relationships between urinary dopamine levels, arterial blood pressure, and monoamine oxidase activity.

All values represent means of six groups of male rats (table 10) at the times specified on the abscissa. 


\section{TABLA 11}

Pereeat ehangee in erinary depunino levels, arterial Slood presoure, and monoulatie exidese setivity."

\begin{tabular}{|c|c|c|c|}
\hline Pollowing & $\begin{array}{l}\text { Dopentine } \\
\mu \mathrm{L} / 2\end{array}$ & $\begin{array}{c}\text { BLoed Pressure } \\
\text { ven Hg }\end{array}$ & 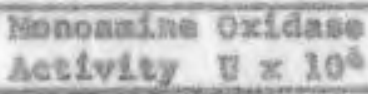 \\
\hline 2nd opar. & 8 casus & CGange & 8 Chanse \\
\hline Contreol & 6 & $\frac{6}{6}$ & 5 \\
\hline 1 & -15.5 & 414.6 & \\
\hline 2 & -16.3 & +21.3 & \\
\hline 3 & -13.1 & 434.4 & \\
\hline 4 & -15.1 & 437.7 & \\
\hline s & -6.8 & -42.8 & -20.2 \\
\hline 6 & +25.6 & 451.7 & \\
\hline 7 & $+12,7$ & +34.1 & \\
\hline e & -24.5 & 450.0 & 10.0 \\
\hline 9 & 423.5 & 460.7 & \\
\hline 10 & +41.2 & 458.2 & \\
\hline 11 & 412.5 & $+50,0$ & (2) \\
\hline 12 & +51.9 & 496.8 & \\
\hline 13 & -1.6 & +30.9 & -35. \\
\hline
\end{tabular}

* A21 value regresent medab of sLx groupe of cule zats (table 10) at the the apecistad in colum one. 
50.

4. A negression Analysis, ineluding a Teat of the liypothesis and Confidence Limits, of Blood Pressure on Logarithm Dopastine is presented in TABLS 12, FICUBS 8 and on BAGI 52. 


\section{TNALE 12}

Deta for the regression of bleod prasaure on logardthe dopaninea, b

\begin{tabular}{|c|c|}
\hline Blood Dresoure nas Hg & Log,. Dopanine Coneentration \\
\hline 140.00 & 2.73400 \\
\hline 148,00 & 2.74974 \\
\hline 164.00 & 2.75716 \\
\hline 266.00 & 2.75740 \\
\hline 275.00 & 2.79727 \\
\hline 185.00 & 2.69487 \\
\hline 188.00 & 2.87622 \\
\hline 183.00 & 2.95324 \\
\hline 196.00 & 2.91900 \\
\hline 293,00 & 2.97720 \\
\hline 133.00 & 2.87910 \\
\hline 384.60 & 3.00885 \\
\hline
\end{tabular}

This togresalon is valid for concentrations of dopandme ranglag Iroa $500-1000 \mathrm{j} / \mathrm{h}$ and $\mathrm{L}$ independent of tima.

biloed presaure and Copanine values are taken fron thble 10. Control

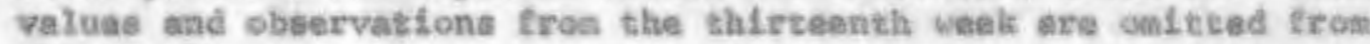
thi.e maiysis. 
2egreasion Anglysibs

a -280.64

$\mathrm{b}=+159.57$

Rograenton equation: $\quad \boldsymbol{x}=a+b \log (x)$

$\mathrm{x}=-280.64+b \log (x)$

Regrebalon coefficleat $(r), 0.8664$

Coesteient of deterrainat 1 on $\left(z^{2}\right), 0.7201$

Test os Hypothesias

18: $P=0$ (20ot of stutiatical depondence)

2.05(2i-2) $=2.228$ (Percentage points of the t-Uotribution)

$12 / .094$

Conftance Llatis: $2^{6}$

$g_{e}^{2}=96.09$ (Ctaviard erzor of the sosthate)

$S_{b}-\$ 1.65$ (Standard erroz of the zagresaton coetetielent of b)

$s_{\mathrm{a}}=90,48$ (Standard erros of the regruacion eectglelent of e)

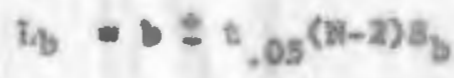

$2,=230.09$

$\mathbf{L}_{2}=89.09$

$t_{e}= \pm .05(\mathrm{v}-2) \mathrm{s}_{\mathrm{a}}$

41.79 .05

$\mathrm{u}_{2}=-4 \mathrm{a} . \mathrm{x}$

6. AII caleulations coneerrad with the regression analyals, teat of hypothaaes, al conflenes Ifralts ware pertonaed according to ontle (1954). 
53.

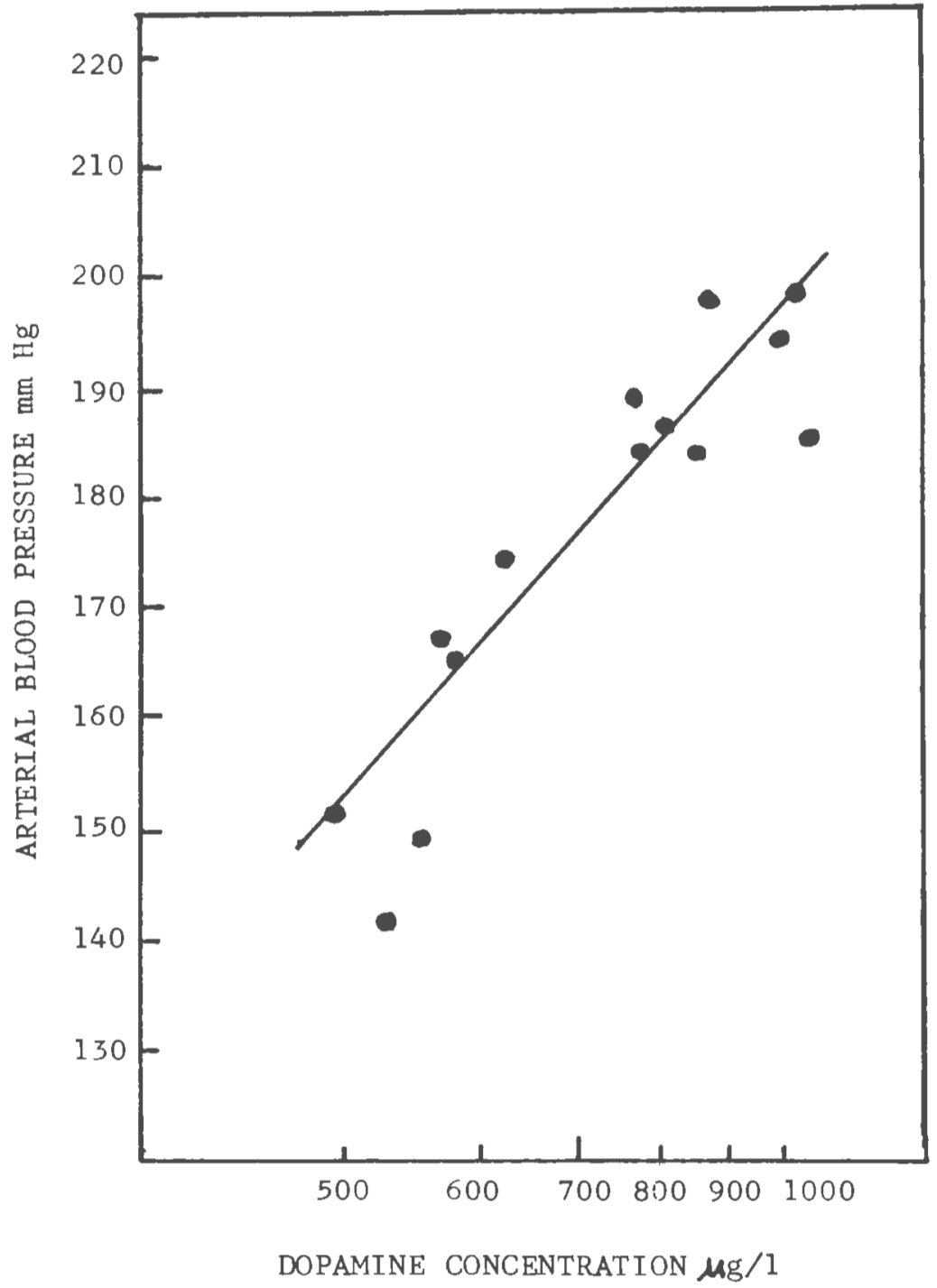

Fig. 8. Regression of arterial blood pressure on logarithm dopamine concentration.

Mean values of six groups of male rats. This regression holds for values of dopamine between 500 and $1000 \mu \mathrm{g} / 1$. 


\section{TV. Dracosson}

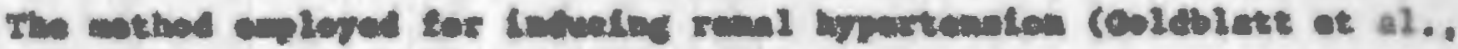

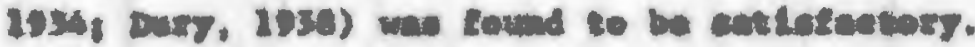

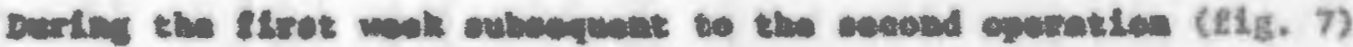

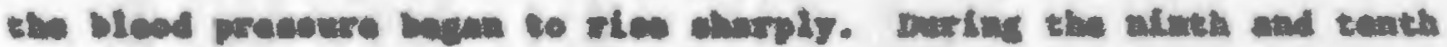

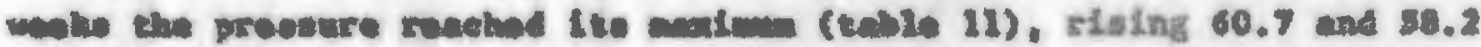

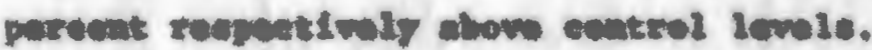

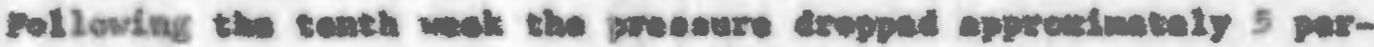

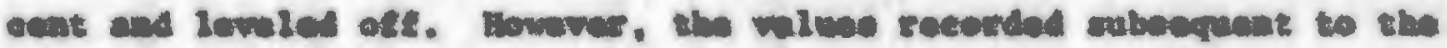

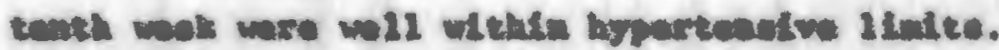

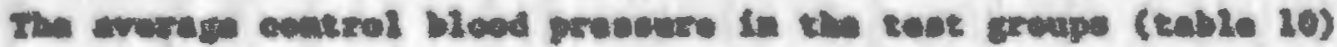

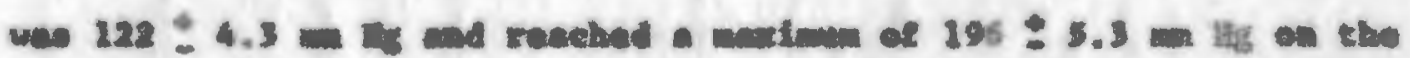

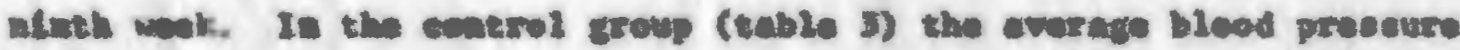

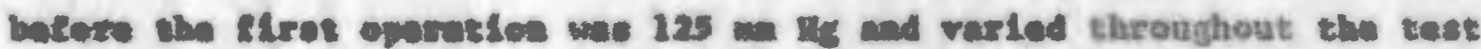

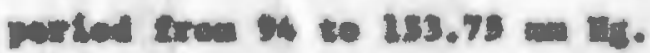

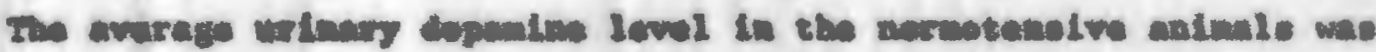

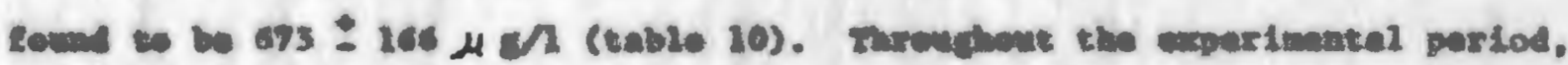

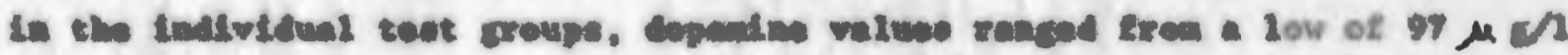
(unte s) to aty of $1369 \mu \mathrm{ch}$ (table 6).

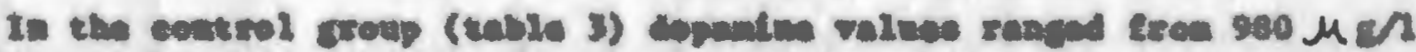

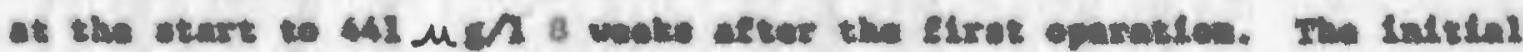

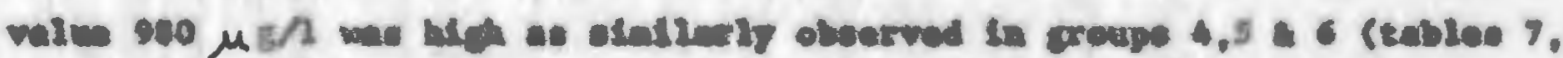

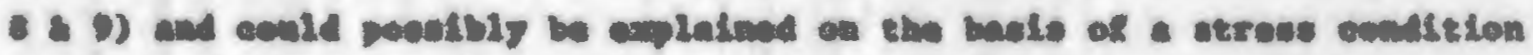

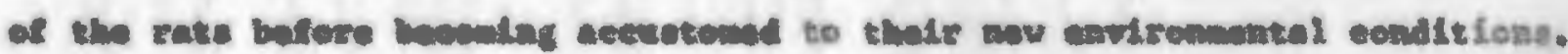

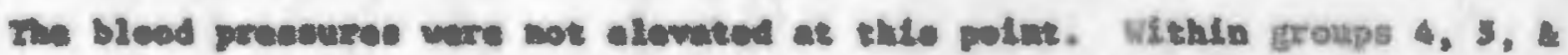

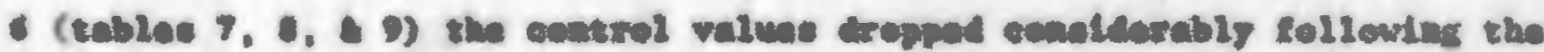

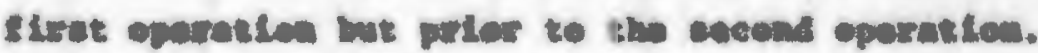




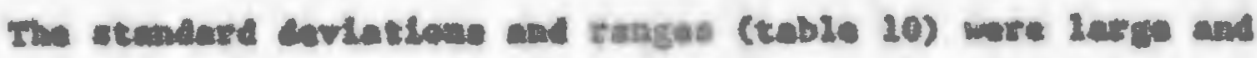

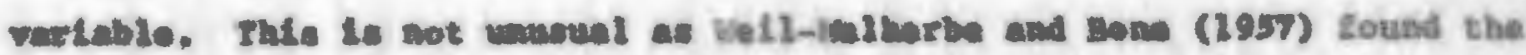

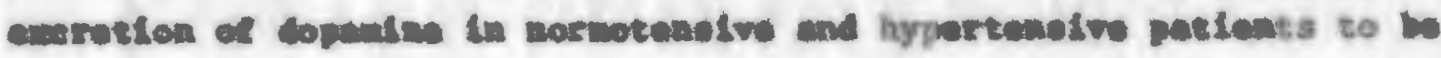
fult wartale. Drufon at a. (1939) reported that dopandm encruted by and over 24 bour melod rasged frea $26-595 \mu g$.

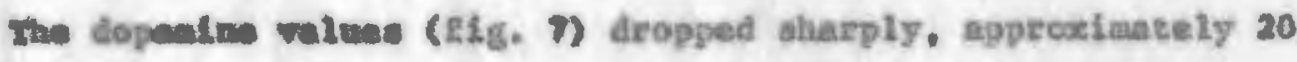

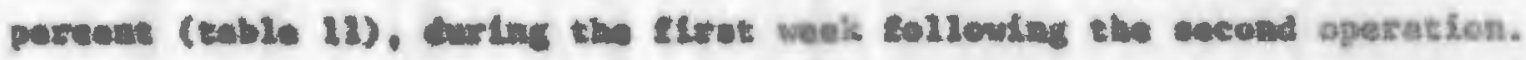

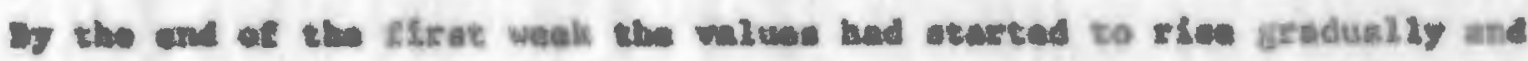

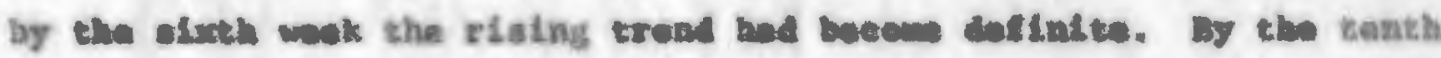

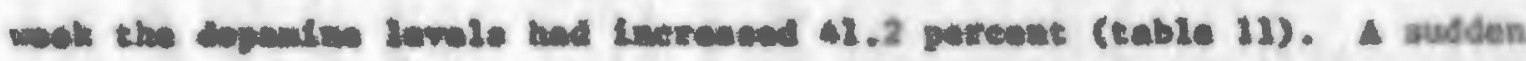

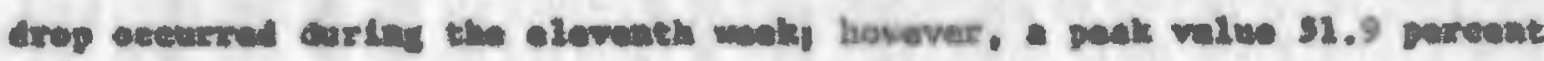

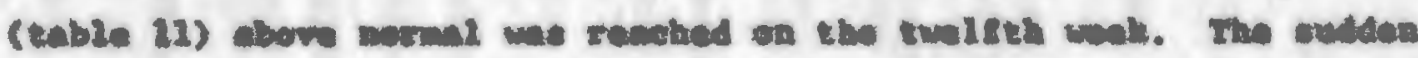

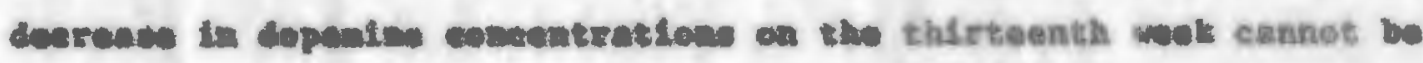

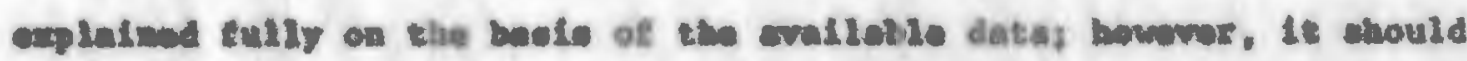

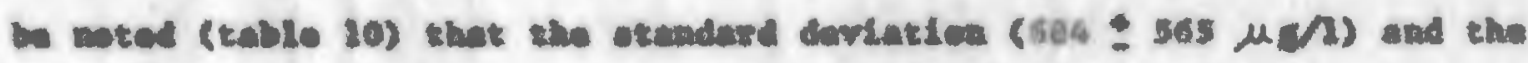

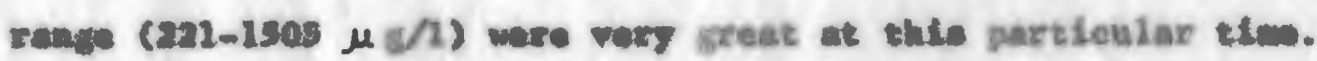

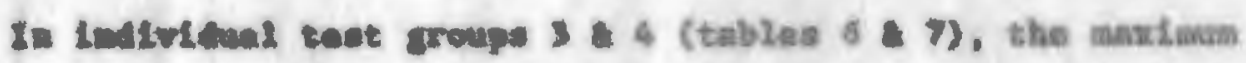

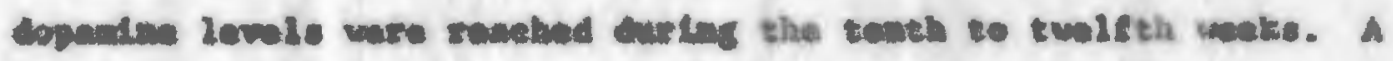

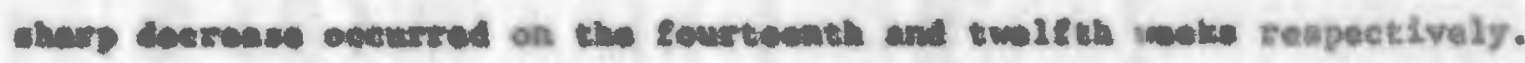

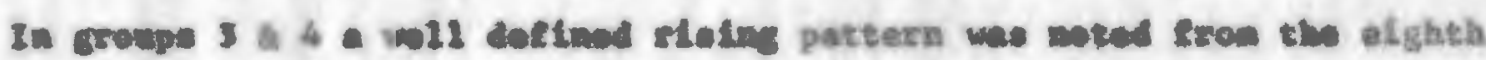

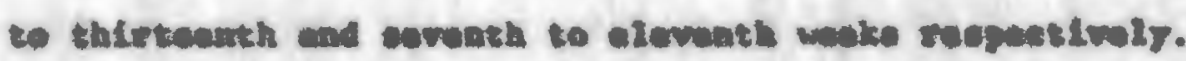

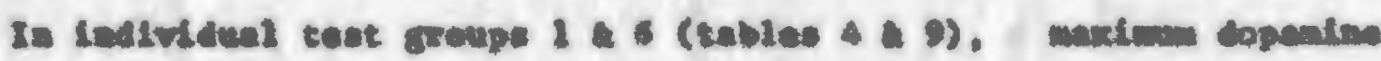

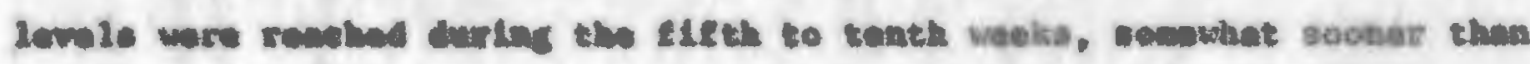

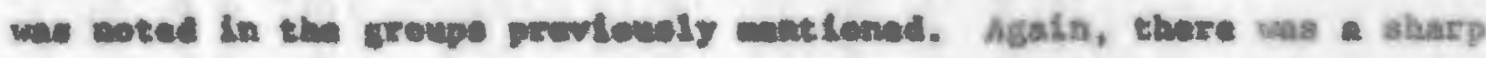

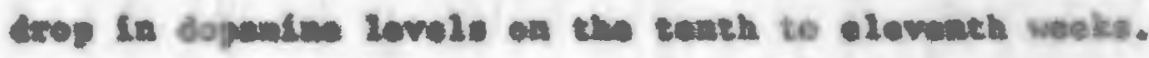

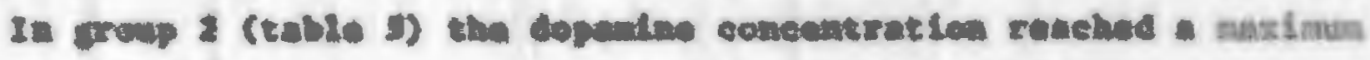

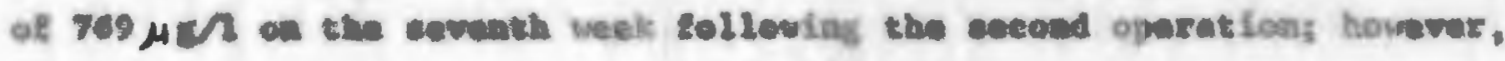


the rise vas wot as pronlwont as that of the preceding groups. In this group the bleod preseure reached $170 \mathrm{ma}$ is which is also not as high as the melna preseuree soted In other groupe.

In group 5 (toble 0), the dopanine values reached sextaun lovie of 1068 and $1032 \mu \mathrm{h}$ on the elghth and twolfth weeke raprectivily. The loval foll quite aharply betwean the two peaks and again aftor the second peak.

Rooulte frow the regrosolen andyale of blood preseure on logarlehe of dopentwe are chown in figure 0, table 12, and page 32. The analyals wav eondueted on the data popled frem all sroups (table 10) excluding

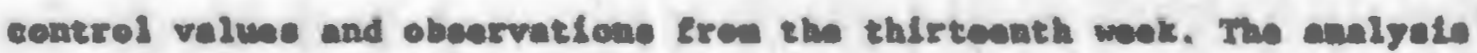

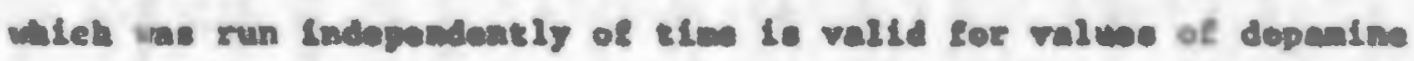

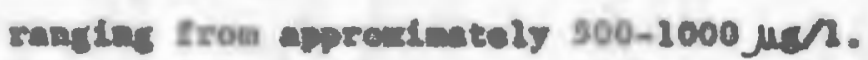

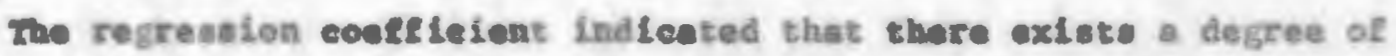
Ilnear ascesletlem botween blood prescure and dopailne concontrat lone. The magltuch of this corralation we 89 poreont.

The coffletent of deteralmation indented that 72 percent of the vorletlone occurring In $x$ (alood Pressure) eould be axplatnod on the

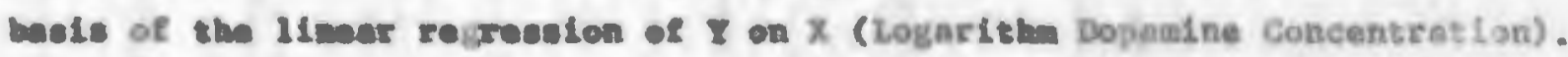

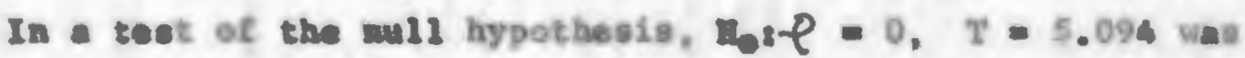

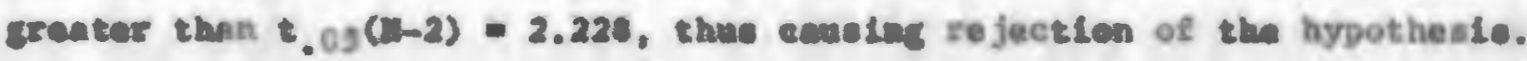
The hyothols, $\mathrm{H}_{\mathrm{o}} \mathrm{P}=0$ otate the the two verlables procetat are otat otically Indapendent, thu rejection of the upothole in this cane ohowe that I (Dlood Presoure) and $X$ (Dopanine) are, In fact, otatistically dopadent. The pereatege polste of the t-detribution were taken at the 0.05 Ievel and, therafore, the reculto of thio particular test can be aceepted vith a 95 parcont eonfldane. 


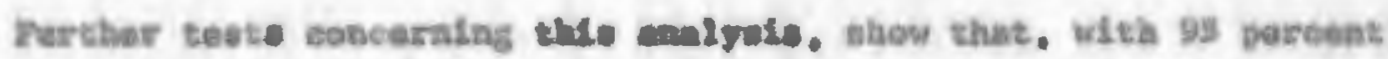

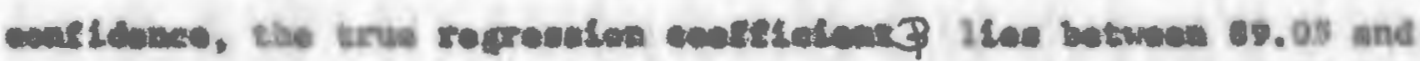
230.09 and that the tres regreasion ecoldetent $K$ ILe batioen 79.05 and $-42.23$.

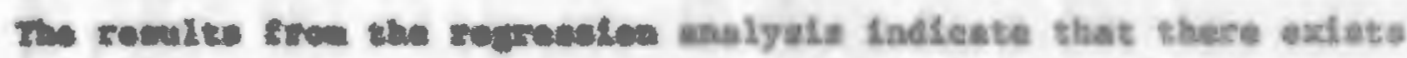

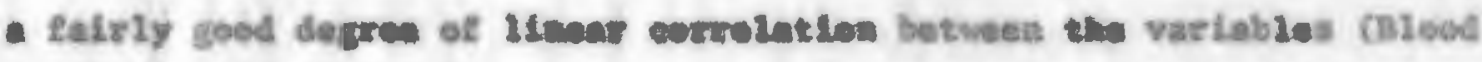

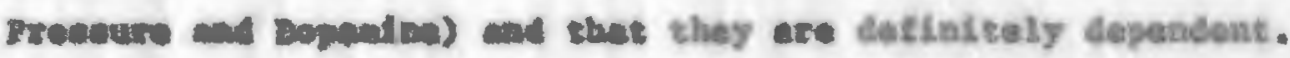

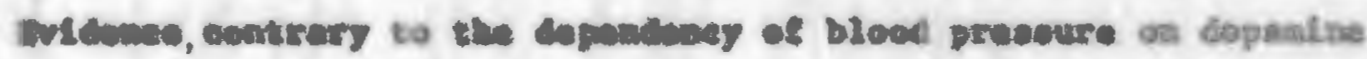

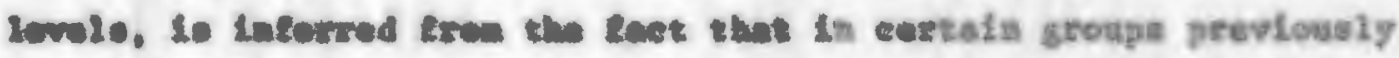

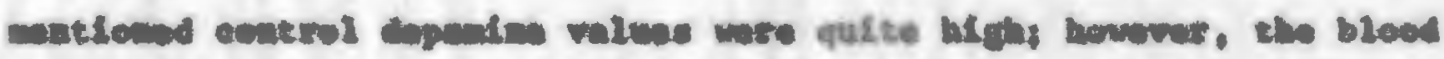

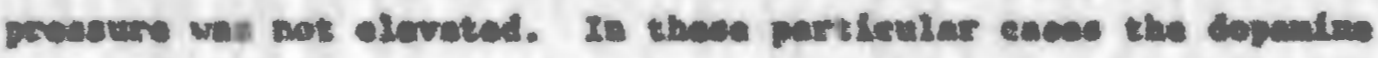

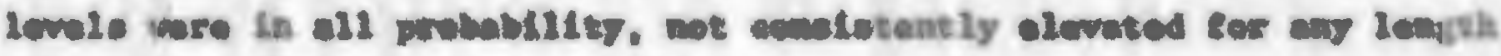
$a$ tins.

Consiesting the ancive als groups in general, it can we ween (IIIs.

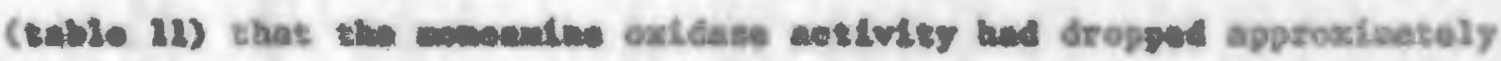
3 pereent dundng the Llret $2-3$ weeks following the accend operation.

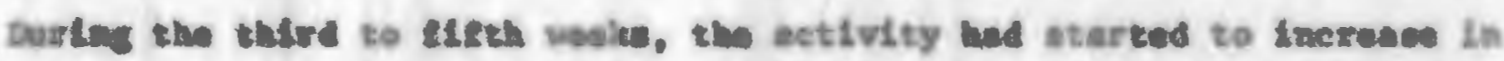

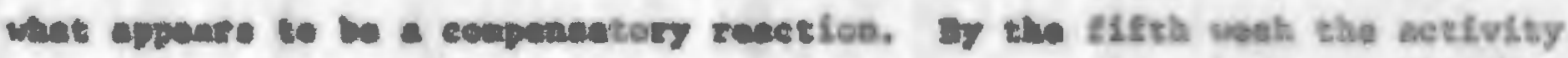

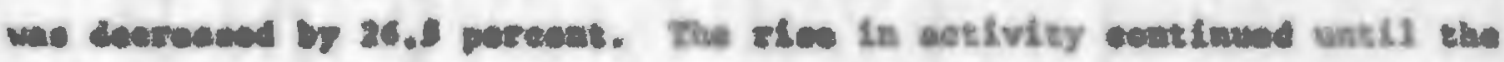

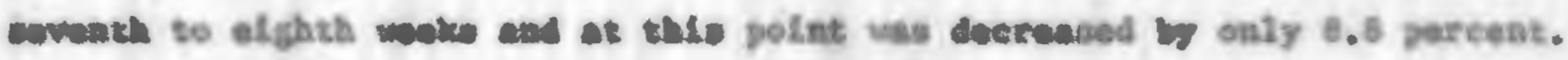

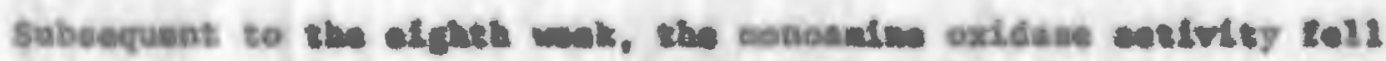

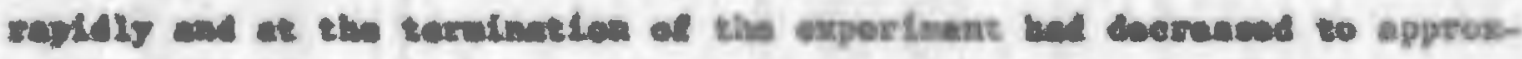
imately 50 percent of the control viles. The Rlading of the uletmate

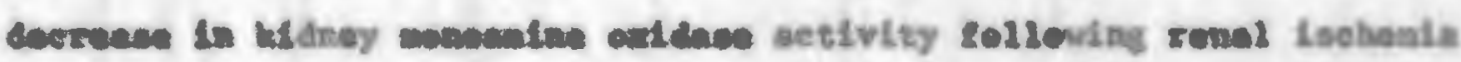

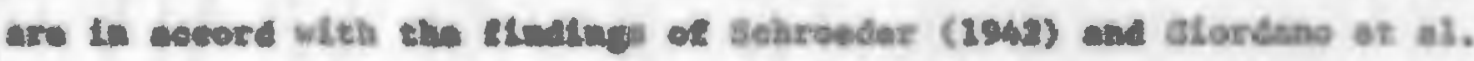
(1099).

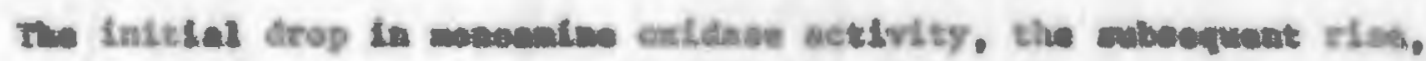

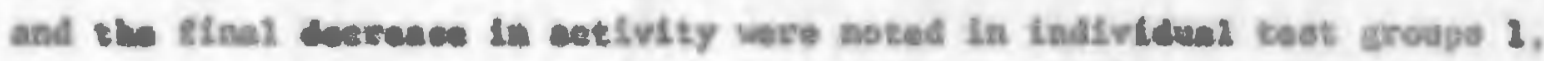




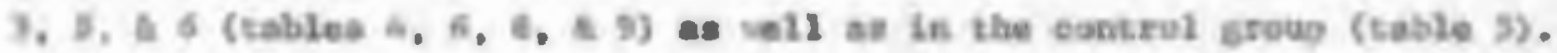

In group 2 (table 5 ) no aigateleart ehanges in motsonalne axidese netivity were noved. Cn the basis of the number of sbenrvations (2) in Groub 5 (table 7 ), the endatenes of an actual trend eould not be soen.

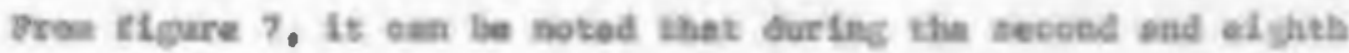

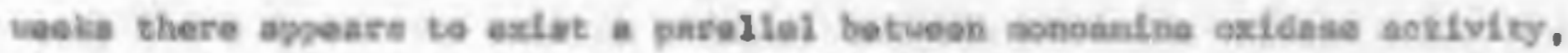
đopanine, and blood preasure of all are Inereasing. Arter the efforb vesic the aonoenine oxldabe octivisy scarted to fall bat the dopaeins and Dlood preasurs ecotinued their rising tretis.

The atghest blood pewasure valuen (table 11) vere reeteded during the alnth to traifth weeks. Durtig this perlod (table 12), the dopantre values vere as theis higheat Iovels and the monoarine cadduss octivity uns Calzing ott aharply.

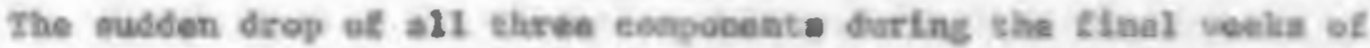
experinenkation cennot be explainad on the basiz of available dats. Tog peasible emplanationis, in regned to the gorreiation betueen

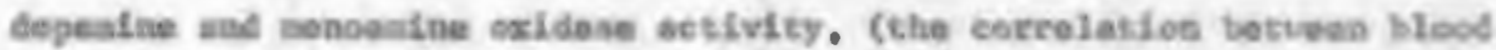

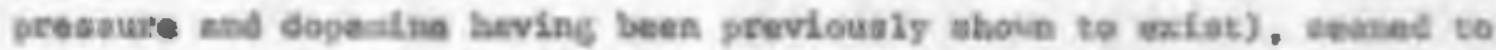
be ouscated froa the analysis of the dats pooled from all sis teit: stouse.

The first is thes the compensatory rise of mobdalne oxidase

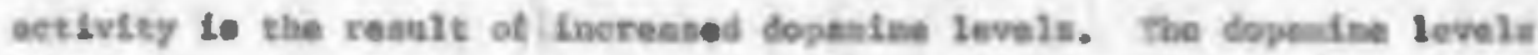
havind increaned is the hypertemalve vtate bue to factara nat wiveldatad troe chls Ixventigation. This, ae has been peoviously pointed out, den

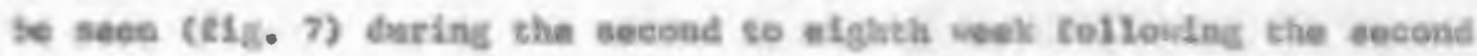
operation. In group 6 (tab 209 ) the dopanaine valuns vere at thelr higlieat values durfsy the elacth to eleventh veeley the blogd preasare whluav ware 


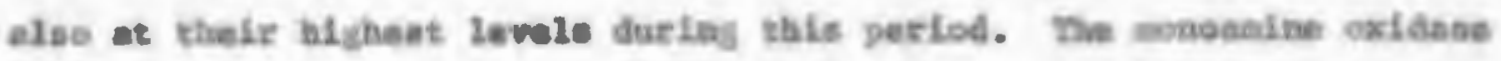
ectivity was, havever. undergotng a epepentatory rice froa the litth to

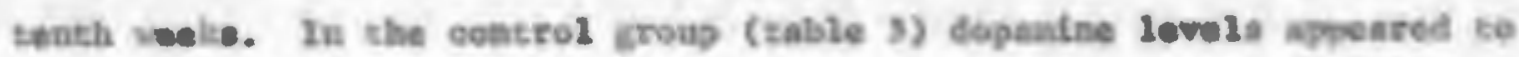
be coapletely Indepandent of aobeasine activity.

The eecond explanation is that oopenine levele inereseed by vircua of deoresaed nonoanthe exildean astivity. Fros figure 7 it can le noted

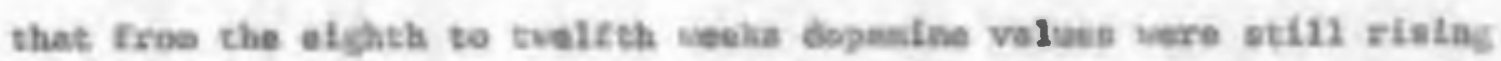
sed during this period rasehed, aloes whl the blood prewoure velves, their peak values. On the other band, mooediae oxidase activity vas Aropping oft eharply during this peried. In suppote of this secowd explanation, it is ahoma in growp $\mathbf{2}$ (teble 5) that monoaelae oxidabe ectivity did noe af guificanty ehange buefag the oowat of the axpertaen: abd that the copealne levele cose only slightly. The blood prassure here reached high of 170 ane Mg. Iover than the naximan valose obtained in ekber ceot crough. In group 5 (teble i) the topanite and bleod pressure

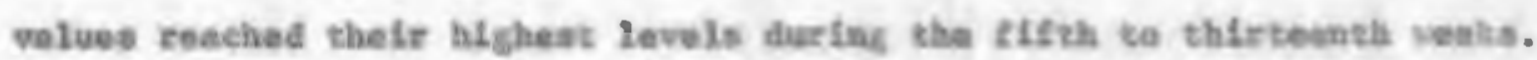
the soneanine exfdese activity wa decreanilug durfing safs period.

essulte troa the investention indeate that slood preasate in

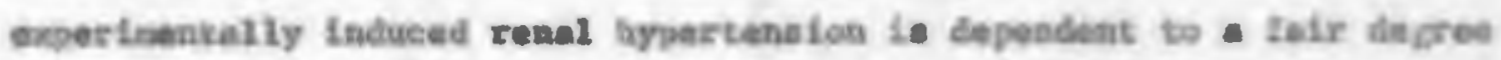

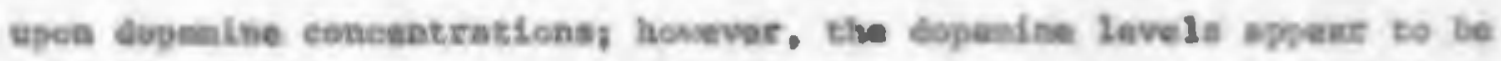
fndepondent of nonowine cxilace betivity. On the basfo of thia independebice,

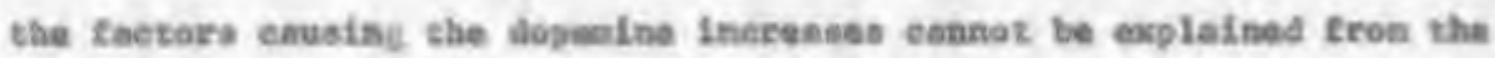

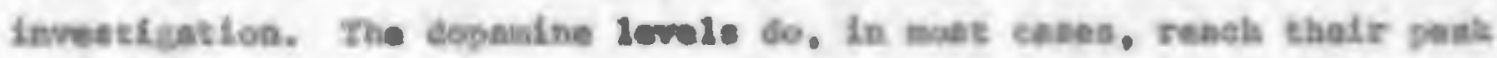

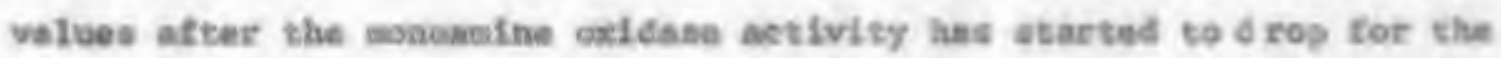

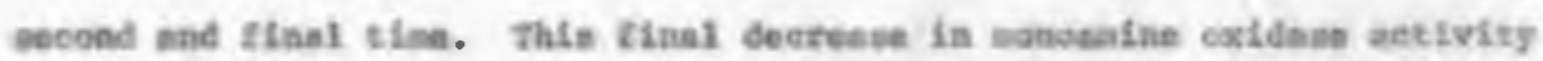

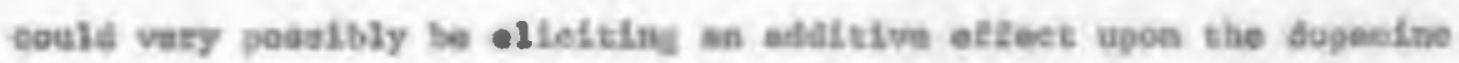

\section{Ievele.}




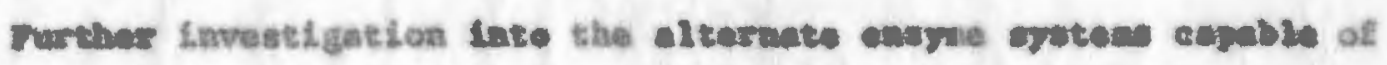

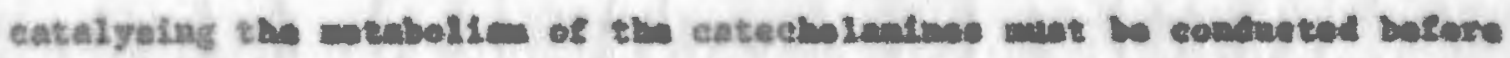
the fncreasea in dopabine concentratione obvarvad in tho otudy ean be 8u12 uplatind. 


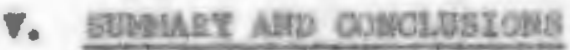

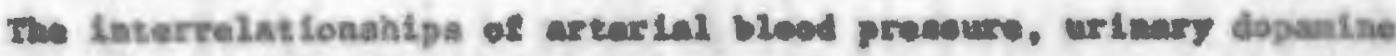

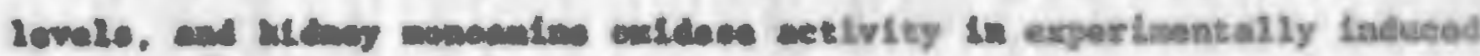
roval hyportenulen has bes inveatigated.

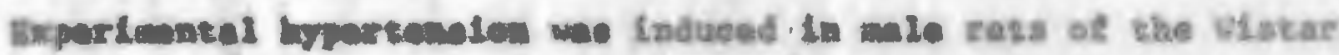

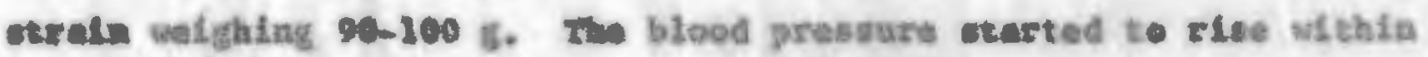
the etret woot following the sacond operation and remehed the "hyper-

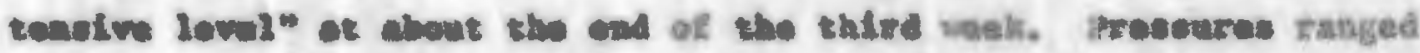

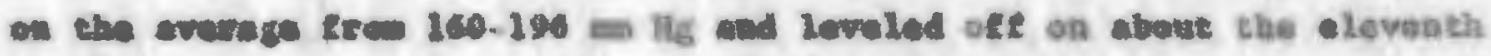

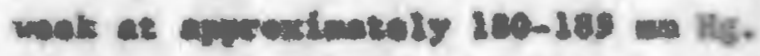

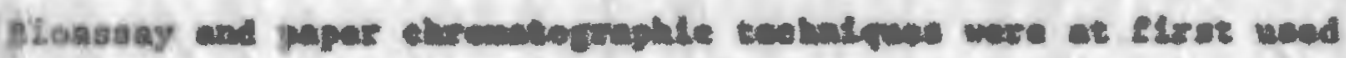

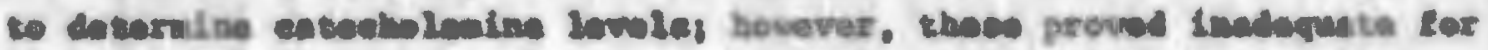

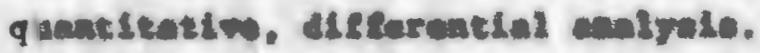

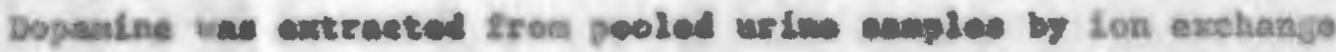

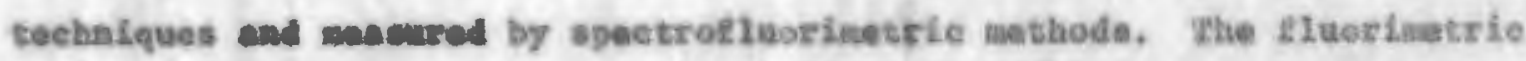

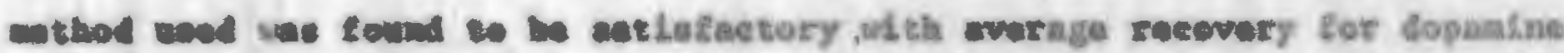

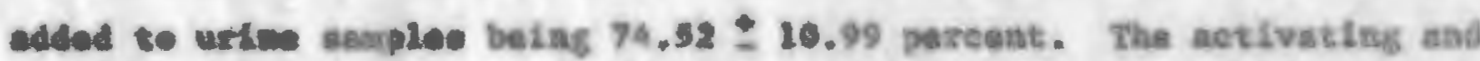

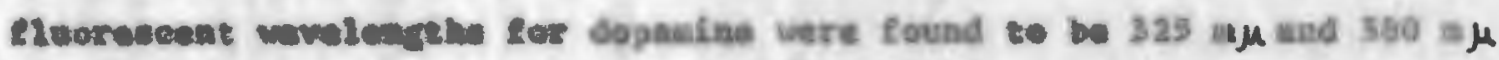

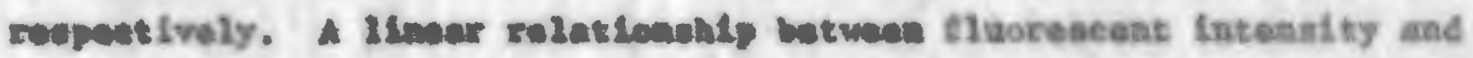

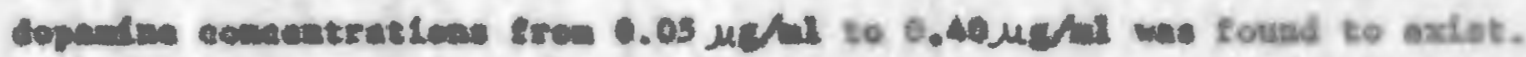

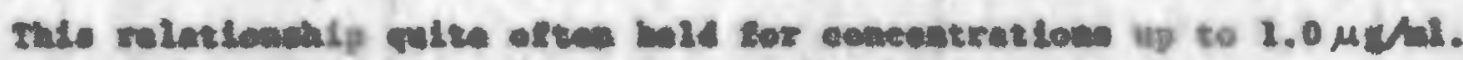

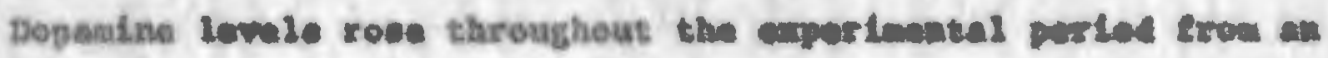
ancege entarol value of $973: 264 \mu \mathrm{M}$ to on averege peik velue of

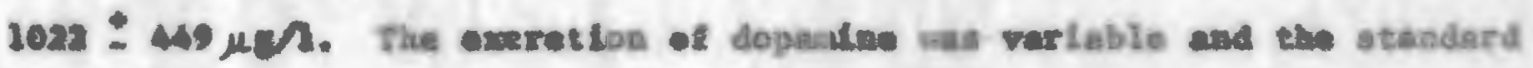
dovlation and renge ware aften lazte.

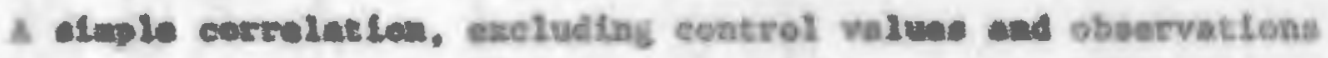

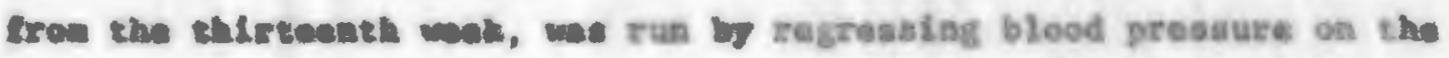




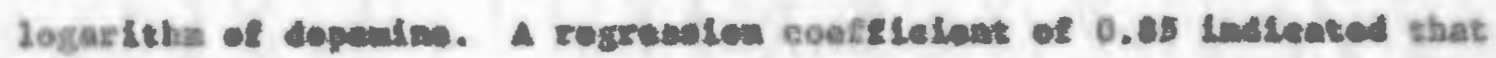

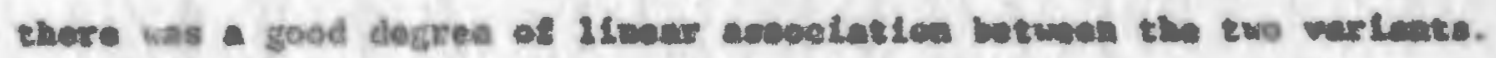
The ceaffiefent of catcratuation, 0.72 , chowad that 72 pareent of the

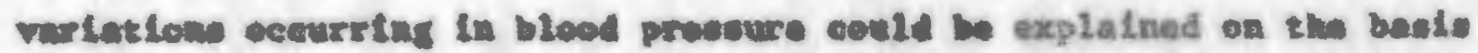
of th linear regresalon of blood prevoura on Gopasine. The roxpocion

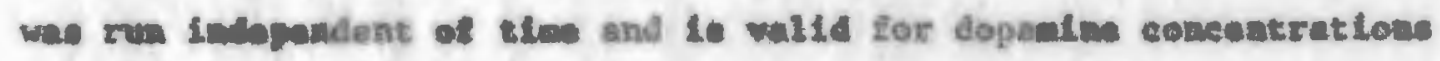

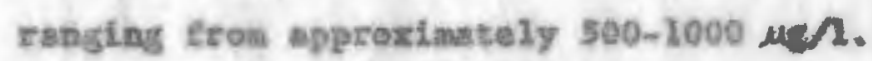

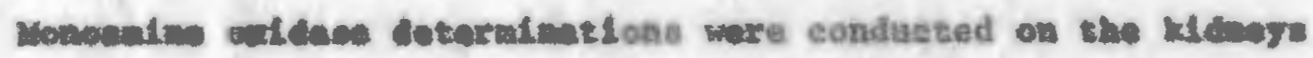

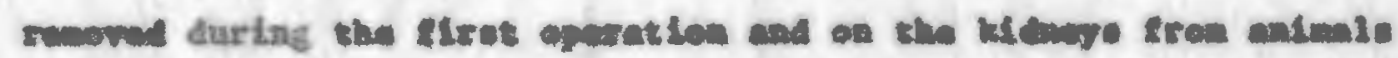

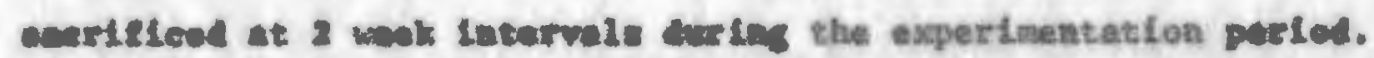

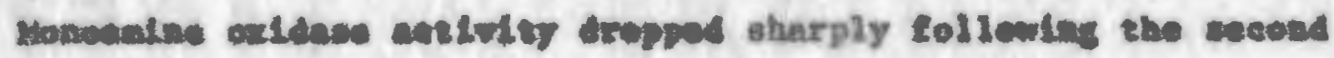

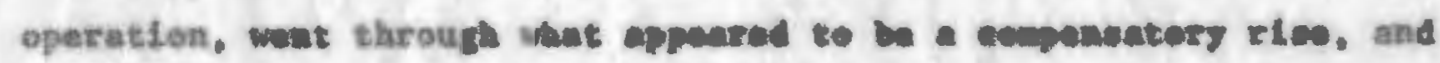

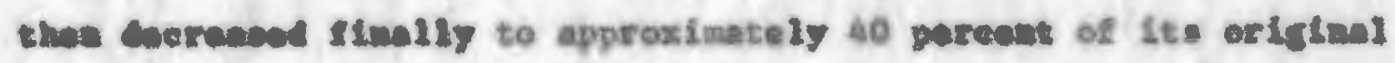
actrity.

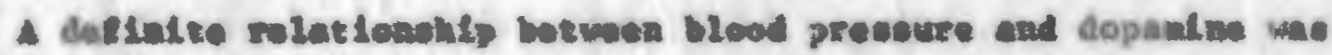

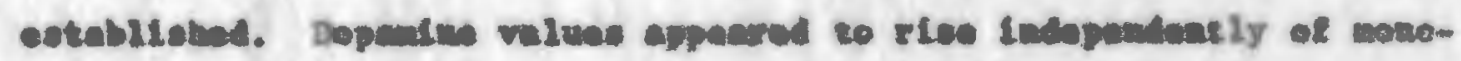

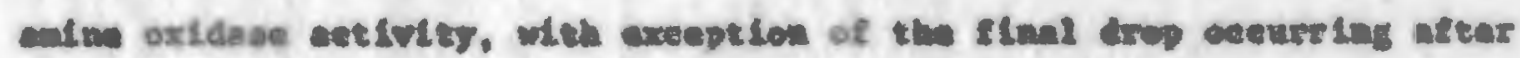
the conpeasutory riae. Here on achetw oflow of the decreasing cono-

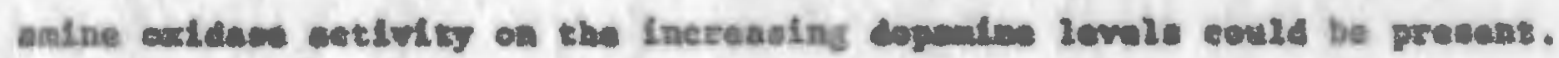

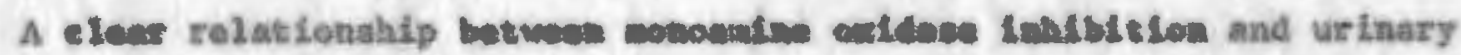

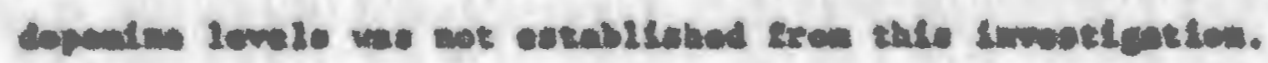




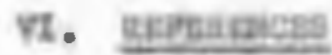

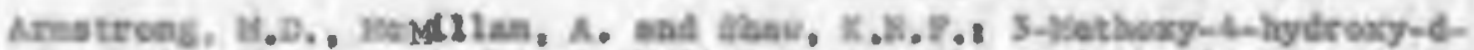

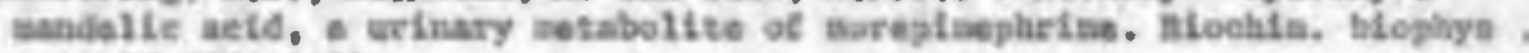
Acte 25:422, 1937 .

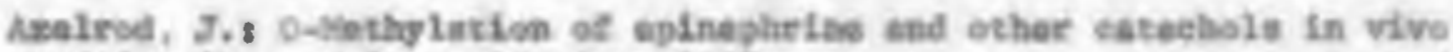
and in vitere. Beiene $125,400,1957$.

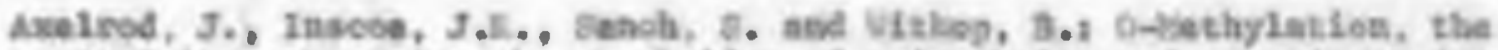
priaciple patmuay tor the netabotian of egtnephriat and noresinaphrine in the rat. Mfochle, bioplays. Aeta 27:210, 1956a.

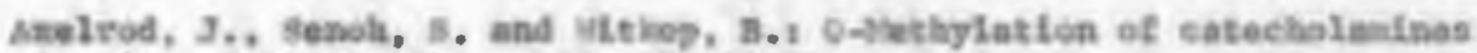
is vive. J. Blol. Ches. 235, 697, 1952 .

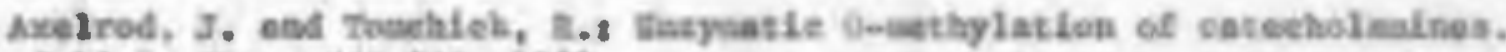
J.blaz. Ches. 233t7c2, 1958.

Arelnod, $J_{\text {. }}$ The antaboliss af eatecholmaives in viva and in vitro. syaposion on Catechaleatias, Harnacel. Hev. 11:402, 1959.

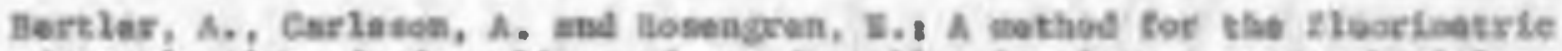
deterninntion of efrenelise abd nosadrenaline is tswoed. Meta physiol. scand. $40.275,1954$.

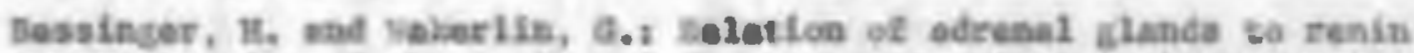

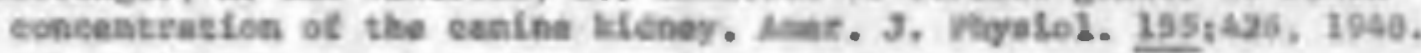

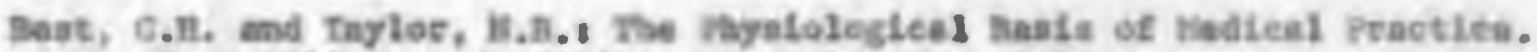

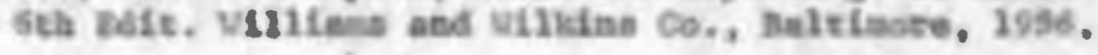

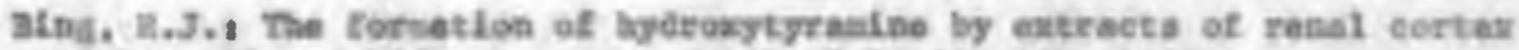
end by pertused kidneys. Aner. J. Phystel. 152,497, 1941.

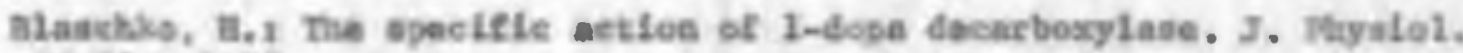
96t 300,1959 .

alasehko, H., llotton, Y. and stanley. C.I tenayatie tocuatioa of ptensar cines. J. Phyaie 2. 20, 427, 1049.

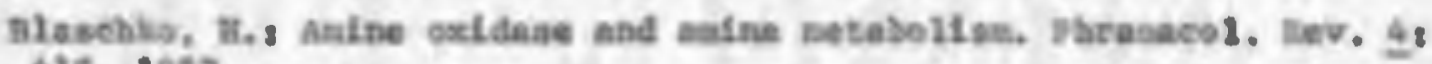
41. 1952.

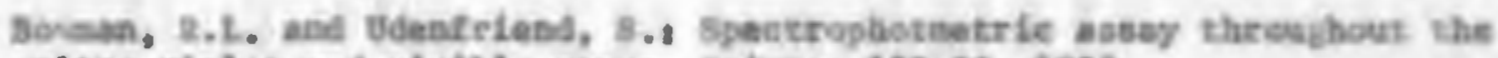
a tra-vielet and viable range. Selente $122,32,1995$.

Arande, V., Dubin, K. and Blapelratein, L. Studies oe salt bypertenafan

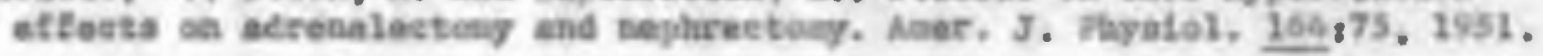

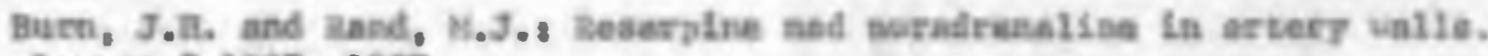
tances 2,1057, 1957. 
burn, 3.1I. and lave, K.J.1 tha deprenmor aesion of dopaelse and edrealine. Arit. J. Pharmacol. 13,471, 1958.

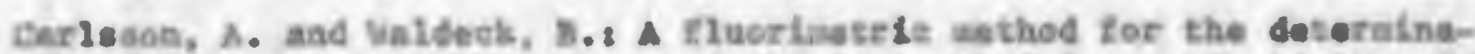
too of dopmalne (3-hydronytgranine). Aeta physiel. seand. 46,203, 1956.

Colline, 5.A- Rypertehsion tron conetrleted arterles of denervated lidneye. Aaver. J. Whyalo1. 116:615, 1934.

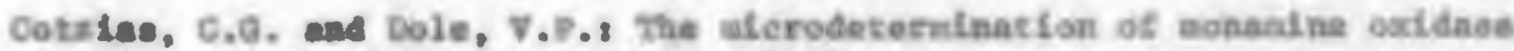
Is zicouoe. J. hLlel. Chen. $90,655,1951$.

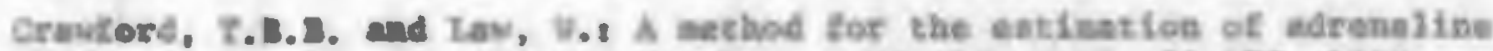

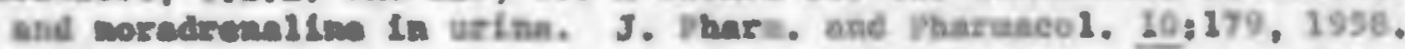

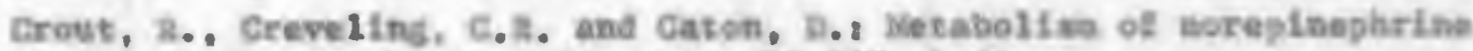
by ret braln ane heart. 7ed. Yroe. 19:297, 1960.

Desis, D.J., Blaschko, M. and Veleh, A.D. The converaion of disydroxyphenglalanine to $-2 \mathrm{c}^{14}$ (Dopa) to norepineplarine by borine adrenal hoopgenated. I. Martacel. exp. Therep. 113,14, 1955.

Deols, D.J., Blasehto, R. and voled, A.B. : The converelos of dihydroxyphenylalanise to $-2 \mathrm{C}^{14}$ (DObA) to noresineplurta by bovin adrenal howogenates. 3. Pharneed, exp. Troerap. 117,200, 1256.

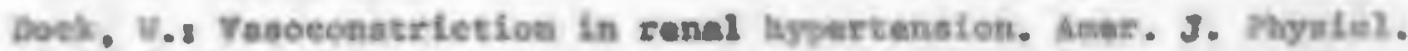
1.1. 1940.

Doujan, R.D., Sourkaa, T.L., Loyne, D.S. and burphy, O.V.: The ditlerenclel deternination of cateoholseises in urine. Cansd. J. MLochen. Physiol. $3781131,1959$.

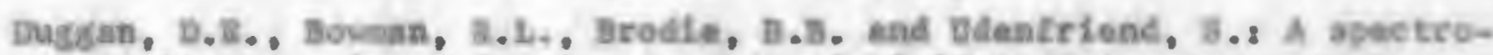

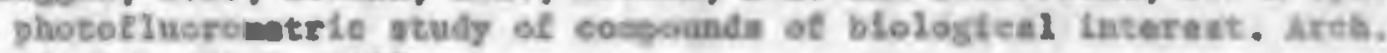
Bfochen. $9.12,1957$.

Dury, D.R.: The production of hypertenafon in the rebsit by a new enthod

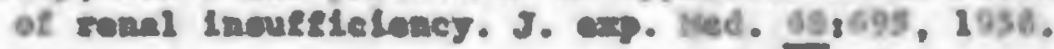

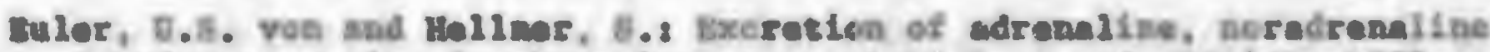
and hydroxytyranine in the urine. Aete phyolol. acind, 22, 161, 1451.

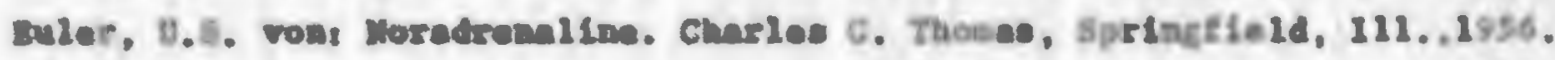

Gedtus, J.1t.: Mleascay procedures. Syeposium on eatecholosined. Dharmaee 1. Rav. 11:241, 1959.

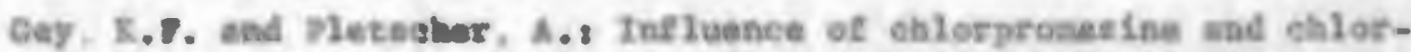
pret disen on the eerebrel netabolian of 5-kydroxytryptandine, noteplnephrine and dopastae. J. Vharaaeol. exep. Thezap. 155:18, 1061.

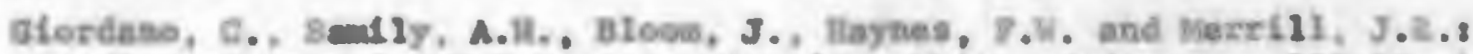
Btudies on experimantel hyporteasibi in rabbits. Bed. Froo. J00,19, 1299 


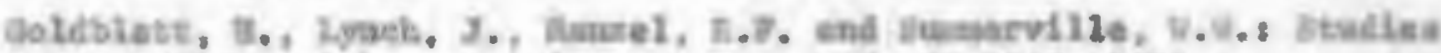

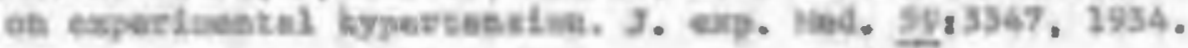

Goldblast, If. Pectora regulating bleqd preakare. J. Kacy Found. Itle Caeferenied, 1931.

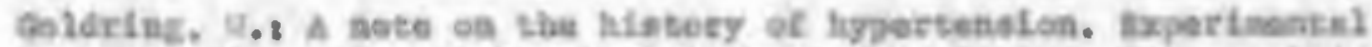
Typartension, spee. Mub. et the II,Y. AEd. Belabten. YoI. 3, 2946.

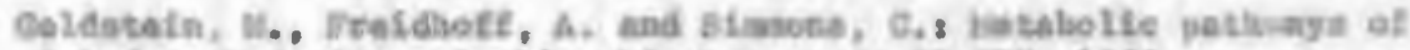
3-hydreosycyradine. Bleehia. biepays. Aeta 12,577, 1999.

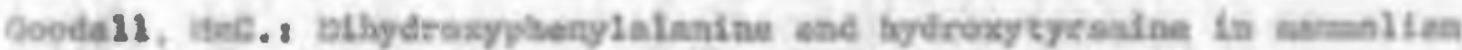
auscarenals. Phariascol. Mev. A,250, 1950.

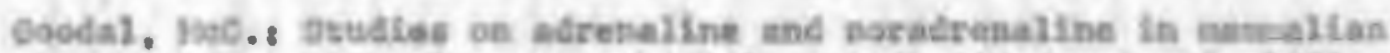

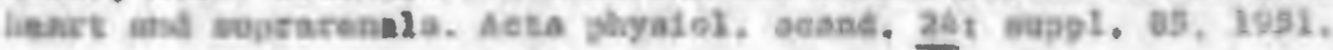

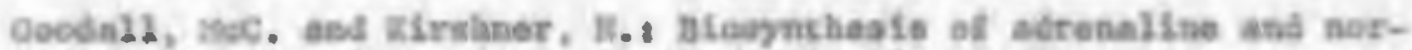
ectranailea is vitro. 3. Blel. Chen. 228,215, 1957.

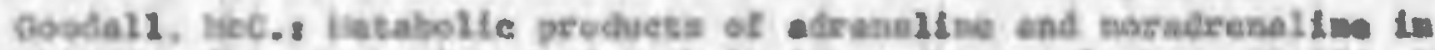

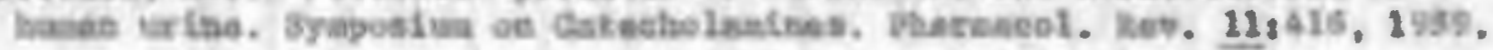

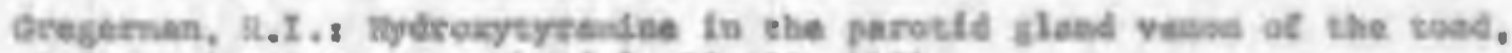
Mubienesinus. J. gen, Thysiol. 35,485, 1931.

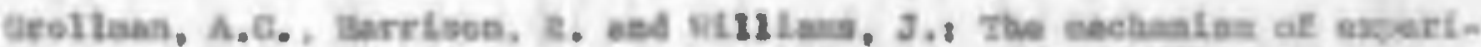

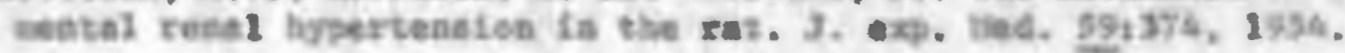

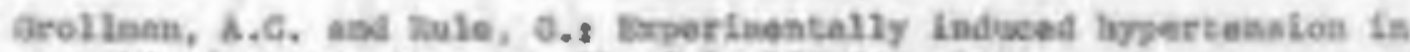

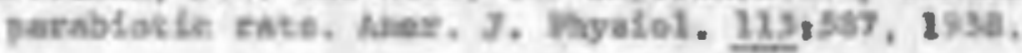

Grollaath, A.0. Experimental shroale hyertenuten in the rabhit. Aner. J. Pleyalol. 142:665, 1042.

Grellnas, A.C. A sing Iffied prosedure foe Isdaeisis chroule renel hyor-

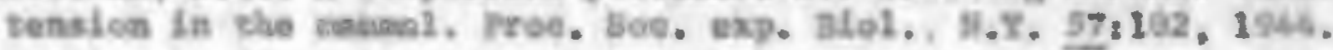

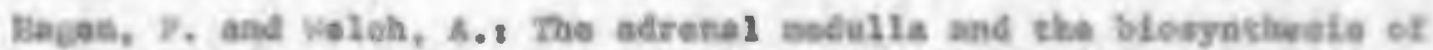

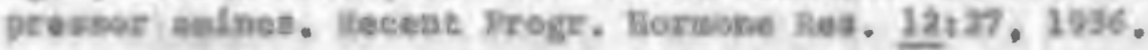

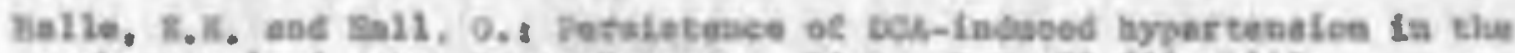

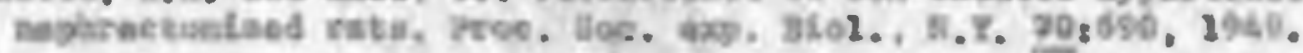

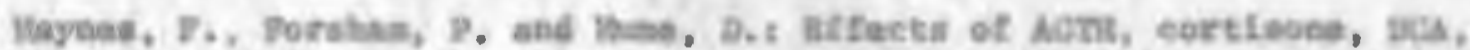

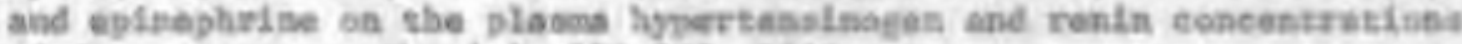

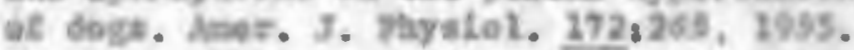

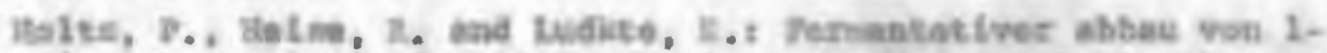

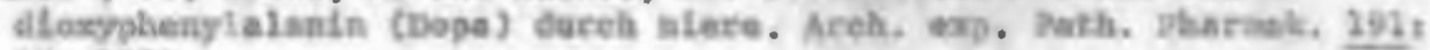
67, 1939.

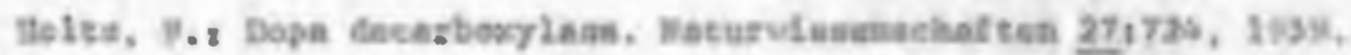


Hornykieviex,0.8 The ection of depanine on she arterlal blood presour. of the guinea plg. BrLt. J. Pharmeol. 15:1\%1, 1956 ,

HorowLte, D., DoldberL, I.I., DJoersdes, A. and Ambrose, I. I Increacad blead pressure reoponece to dopanles and noreplapphrine produced by monoeseine orddace inhilutero in ma. J. Lab. Clin. Find. 56:747, 1960.

Boudobre, Z. and Braun-lianondes, Seeretfoa af renen ty the Intset kidney. Anar. J. Physiol. 137,47, 1942.

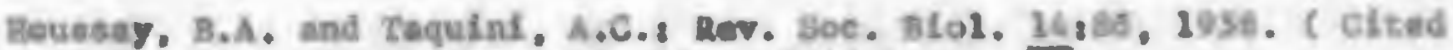
by Coke. Experinental lypertenololl, 1946).

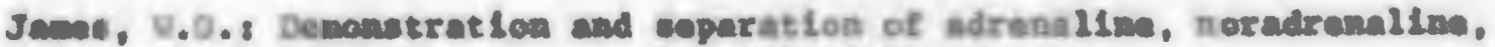
and bethyl streimila. Mature 161,651, 1948.

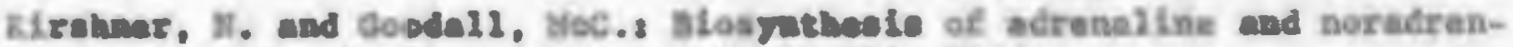
aline by adrenal ollees. Fed, Proe. 15:110, 2956.

Langemann, B., Enayes an substrates in the adrenal gland of tho Ox. Brit. 3. Pharencel. $5,328,1951$.

Lepar, L.C. and Ddentriend, 9.8 S,4-Ditydroxyphenglethylaviae an a precuraor of edrenal epinephrine in the intaet rat. Ped. vroe. 15: 208, 1056 .

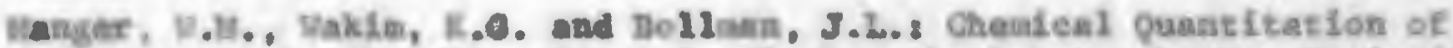

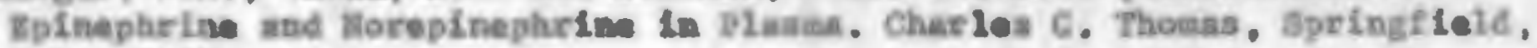
111.. 1959.

thason, M.C.. Corcorab, A.C. and faite, I.A.8 the coaparative activitiet of 17-hydroxy-11-deaoxycortice-oteroht. Andoerthology 45:441, 1950.

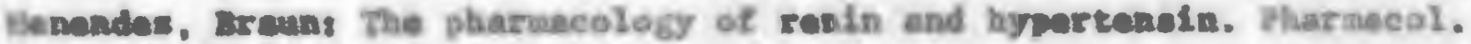
Rev. $8,25,2956$.

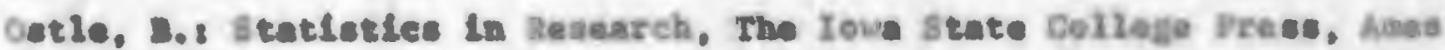
Iove. 2954.

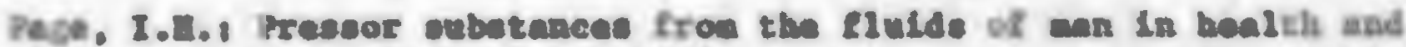
disence. J. axp. 14ad. 62,67, 1935.

Rage. 1.I. and Sweet. J.E., ILLect of hypophyeactoug on the crectal blool preabure of boge with experteental bypertenaion. Aear. J. Mhyalel. $120,231,1937$.

Page. I.I. 8 The production of peralatent arterial bypertension by cel-

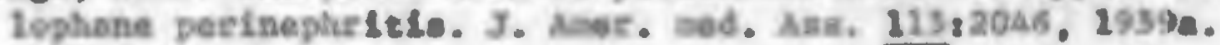

Page, I.A. A method for the produetion of peralstent hypertenalon by sellophane. Belenee $99,273,19396$.

Mage, I.I. Desonstration of ILberaten of reain froto the blood strean troe kibneys ol enleals made hypertenalve by cellophane perinephritis. Aner. J. Phyalol. 130,22, 1940. 


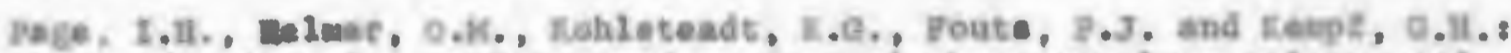
The reduction of artarlal blood preseure in hypertennive patiente snd animals with extraets of kidnoge. J. exp. Ned. $73,7,2941$.

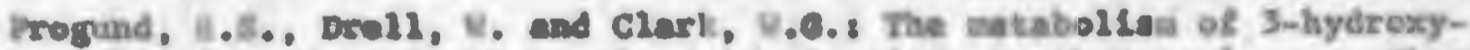

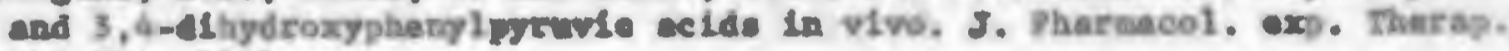
131:294, 1961.

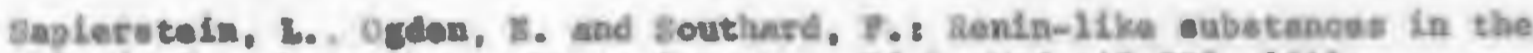
blaed after hemortage, Rroc. Son. $\exp$. Biol. Ked. 48,505, 1941.

Sevy, 2.". and Waksiln, 6.z., Sndoerine Laetors in exper Imantal hypercomalon. Awer. J. Phrelel. 172, 12\%, 1955.

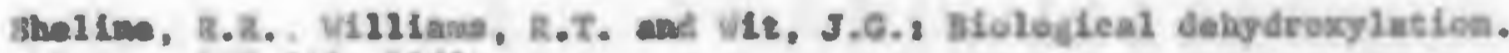
Iature 106: $269,1960$.

Bhepherd, D.M. and ieot, O.B. I lfydrogytyremine and the adrenel bedulla. I. Phyaiol. 120:13. 29s3a.

Shepherd, D.W. and vest, 0.L.: Deteetion of sone precursore of edreneline by paper chroiatography. Wature 171,1150, 19536.

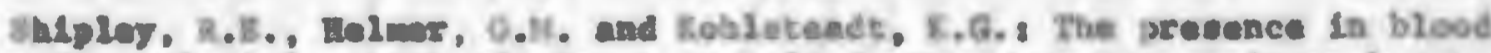
of a prineiple uhloh ellelte a custalned preseor reopenae in nesplrect-

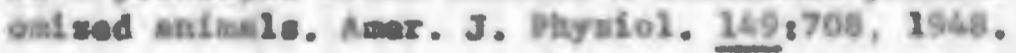

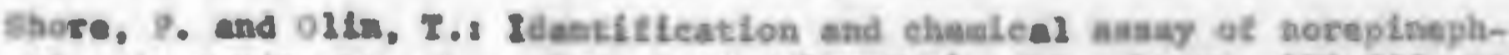

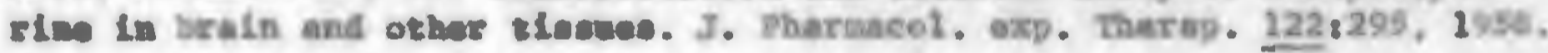

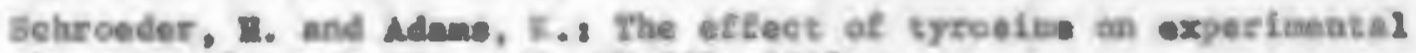
hypertension. J. e.p. Hed. 73,531, 1941.

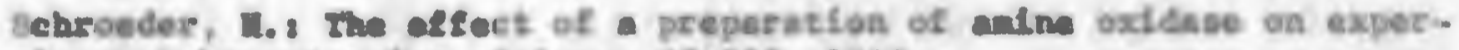
Inentel hypertenaion. Eclence 23,305, 1942.

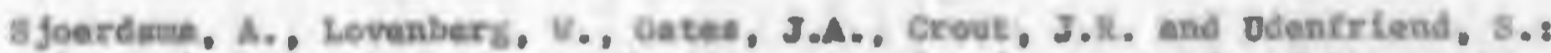

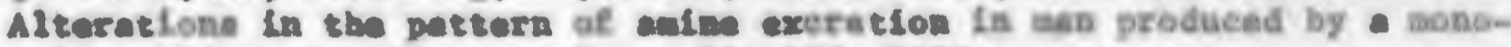
and caldace Imibltor. Selance 130,223, 1959.

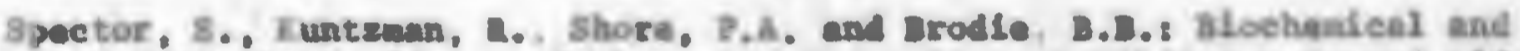

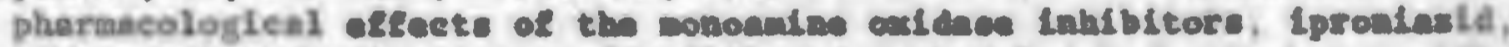

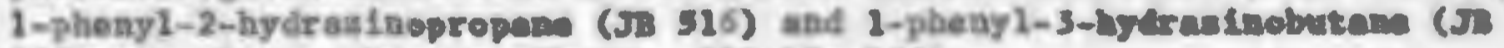
335). J. Pharmeal. exp. Therap. 128,15, 1960.

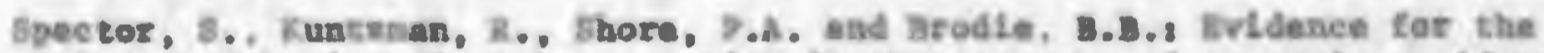
ralcece of beain asines by recerpine in the presence of moedanine oxidkas Inhibltors. Impleetion of monoanine oxidese la norepinephrine netaboliam in the brain. J. Pharaseal. exp. Tharap. 130,256, 2960b.

Tiagerstedt, 8. and Berganh, R.2 Skand. Arch. Physto1. 8,225, 1090. ( Cited by Deat and Taylor, 1956).

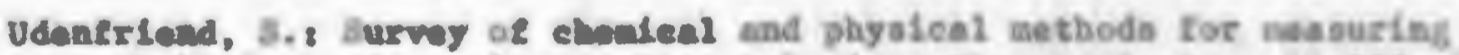
zatecholainlma. Syaposium on Catceholafbes. Pharaeco 1. ReV. 11,252, 1959

Weil-ilaihorbe, M. and Bone, A.D. The estination of entecholenines in

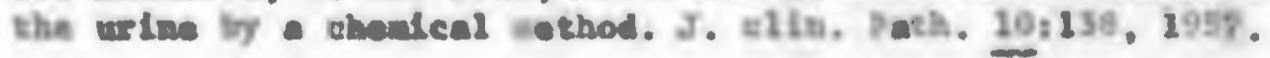




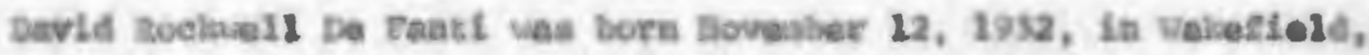

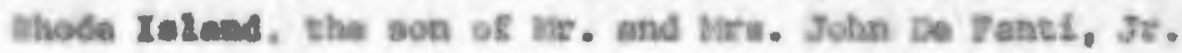

He was graduated tros Colgate Defveralty, Mandton, Bev York, in 2055 ufth the degree of Bachezor of Arte in roology. He etrolled In the Onivoralty of shode Island, College of Arts and seieaces, in 1955 and vas

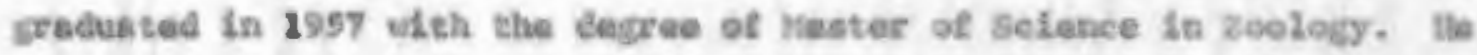
continued ale graduate education in the College of tharnacy, Departnent of pazabeology, at the Daiveraity of phode Inland and eospleted the requireneats tor the degree of Doetor of Philosophy in llovenber, 1961. From July. 1959 through July, 1961 be held a Valted scetes Fub1le Mealth

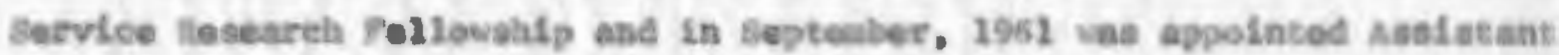
Proteesor of Thernacolegy at the Unimersity of thode Islend.

He Is a sonber of tha folloulng bonor societiest ha chi, wh Siges and 31 mas $x 1$.

Be maveled hary Cotherine Bowret in 1057 and has one chile, a son, John. 